

\section{Editorial Board}

\section{Editor in Chief}

Mark Zilberman, MSc, Shiny World Corporation, Toronto, Canada

\section{Scientific Editorial Board}

Viktor Andrushhenko, PhD, Professor, Academician of the Academy of Pedagogical Sciences of Ukraine, President of the Association of Rectors of pedagogical universities in Europe

John Hodge, MSc, retired, USA

Petr Makuhin, PhD, Associate Professor, Philosophy and Social Communications faculty of Omsk State Technical University, Russia

Miroslav Pardy, PhD, Associate Professor, Department of Physical Electronics, Masaryk University, Brno, Czech Republic

Lyudmila Pet'ko, Executive Editor, PhD, Associate Professor, National Pedagogical Dragomanov University, Kiev, Ukraine

\section{IntellectualArchive, Volume 7, Number 4}

\begin{tabular}{|c|c|}
\hline $\begin{array}{l}\text { Publisher } \\
\text { Address }\end{array}$ & $\begin{array}{l}\text { Shiny World Corp. } \\
9200 \text { Dufferin Street } \\
\text { P.O. Box } 20097 \\
\text { Concord, Ontario } \\
\text { L4K 0C0 } \\
\text { Canada }\end{array}$ \\
\hline $\begin{array}{l}\text { E-mail } \\
\text { Web Site } \\
\text { Series } \\
\text { Frequency } \\
\text { Month } \\
\text { ISSN } \\
\text { Trademark }\end{array}$ & $\begin{array}{l}\text { support@IntellectualArchive.cc } \\
\text { www.IntellectualArchive.com } \\
\text { Journal } \\
\text { Bimonthly } \\
\text { July/August } 2018 \\
1929-4700 \\
\text { IntEllectualArchiveTM }\end{array}$ \\
\hline
\end{tabular}

(C) 2018 Shiny World Corp. All Rights Reserved. No reproduction allowed without permission. Copyright and moral rights of all articles belong to the individual authors. 


\section{Intellectual Archive}

Volume 7

\section{J. Hodge \\ J. Hodge}

M. Perfileev

A. Bolonkin

A. Matchanov

N. Vykhrushch

A. Yakunina

L. Filonenko

Lu Tao

M. Prihodin
Number 4

July/August 2018

\section{Table of Contents}

\section{Physics}

Two different types of magnetic field

Another experiment rejects Ampere's Law and supports the STOE model

\section{Mathematics}

Dense Spiral Packing of Circles in the Plane

\section{Technology}

Flight of Outer Solar System (chapters 1-3)

\section{Law}

The International Search of Persons Committed a Terrorist Act

\section{Education}

The Evolution of Secondary School Reforms in Ukraine in the 2nd Half of the 19th - the Beginning of the 20th Centuries

How to increase the efficiency of teaching Calculus I at college level: Student-

Centered Approach

The Peculiarities of Forming Value Attitude to Another Person in Teenagers of Boarding Schools

A Competency Approach as a Methodological Basis in the Formation of Performing Skills in Future Music Teachers and Musicians From China

The Forming Creative Skills in Future Art Teachers in Pedagogical Higher

Education Establishments

Manuscript Guidelines

\section{Toronto, July/August 2018}


DOI 10.32370/2018_07_1

\title{
Two different types of magnetic field
}

\author{
J.C. Hodge ${ }^{1 *}$ \\ ${ }^{1}$ Retired, 477 Mincey Rd., Franklin, NC, 28734
}

\begin{abstract}
Such luminaries as Richard P. Feynman and Albert Einstein have noted an asymmetry in application of Maxwell's Equations. The Scalar Theory of Everything (STOE) posits the components of the universe are hods and plenum. An experiment to test Ampere's law and the STOE was performed. The data shows the STOE model is very close to the actual measurements and rejects the classical Biot-Savart Law. The results of the experiments suggest a distinction between magnetic fields caused by hods and magnetic fields caused by plenum resolves the asymmetry.
\end{abstract}

keywords: STOE, Theory of Everything

\section{Introduction}

Maxwell's Equations classically describe the relationships of magnetic (B) and electric (E) fields. They suggest two different forms of the action of a magnetic field. When applied to moving bodies, an asymmetry in results arises. If electrons are moving, a magnetic field induces a force related to current and which exerts a force on magnets which are not moving relative to the circuit. When the magnet is moving relative to a circuit, an electromotive force generates a voltage in a circuit $\vec{\nabla} \times \vec{E}=-\frac{\partial \vec{B}}{\partial t}$, where $\vec{E}$ is the electric field and $t$ is clock reading (time). This asymmetry is sometimes noted by such luminaries such as Richard P. Feynman and Albert Einstein (Wikipedia). This may also be the source of the inexactness in Maxwell's Equations.

The Scalar Theory of Everything (STOE) suggests the hods have a greater plenum density $\rho$ held at a maximum on one side and a minimum on the other side which is the magnetic effect. The magnetic field of classical physics is a cloud of hods with the same orientation or the divergence of the plenum field. The density of hods is the $B$ intensity. A current of electrons in a wire ejects hods perpendicular to the wire and the current direction. An experiment rejected the Biot-Savart (Ampere's) Law and did not reject the STOE model (Hodge 2018b,c). The STOE modified Biot-Savart Law for a magnetic field

*E-mail: jchodge@frontier.com 


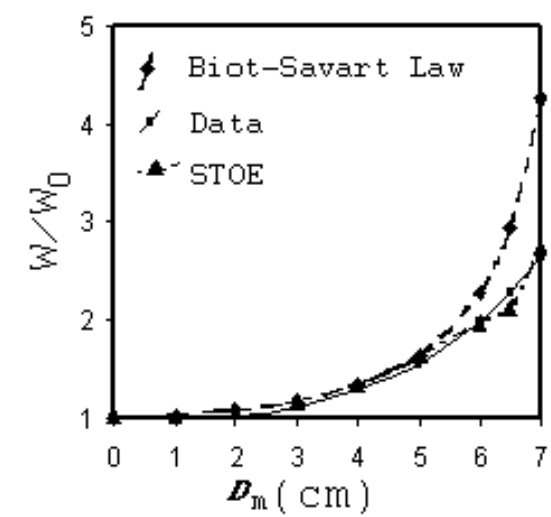

Figure 1: Measured data (solid line) and the STOE calculated data (triangles with dotted line) graph with the Biot-Savart Law calculations added. The $\theta=0.82$ radians. [from Hodge (2018b)]

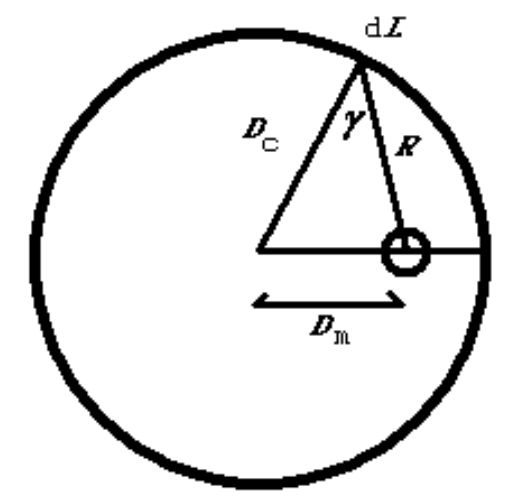

Figure 2: Diagram showing the symbols used when the small, round magnet is in a solenoid. [from Hodge (2018b)]

$\vec{B}_{b}(\vec{R})$ at a position $\vec{R}$ from a element $\mathrm{d} L$ of the wire caused by a current $\vec{I}$ in the wire is

$$
\vec{B}_{b}(\vec{r})=\frac{\mu_{0}}{4 \pi} \int_{c} \delta \frac{\vec{I} \mathrm{~d} L \times \vec{R}}{|\vec{R}|^{3}},
$$

where $\mu_{0}$ is the magnetic constant and the integration is considered to be around the circuit or for an infinitely long wire, $\vec{I}$ is the current through $\mathrm{d} L, \vec{R}$ is the vector from the $\mathrm{d} L$ to the point being evaluated, and .

$$
\begin{aligned}
\delta & =1 & \theta>\gamma \\
& =0 & \theta \leq \gamma
\end{aligned}
$$

where $\theta=0.82$ radians and $\gamma$ are the angles from the normal of $\vec{I} \mathrm{~d} L$ of the spread of the hods and the direction of $\vec{R}$, respectively.

Figure 1 shows the result of the experiment of Hodge (2018b). The calculation of both models at the center of the solenoid are the same because the $\delta=1$ for all $\vec{I} \mathrm{~d} L$. When the test magnet is placed closer to the solenoid (larger $D_{\mathrm{m}}$, see Fig. 2) some of the $\delta=0$ because of the limited diffusion of the emitted hods. Therefore, the STOE model is a good fit for the measured results.

This paper demonstrates the effect of the STOE model of a magnetically induced current in a solenoid. The terms and development of the STOE model may be viewed at Hodge (2018d) and Hodge (2015). The model of the magnet 
moving and experiment are discussed in section 2. The interpretation of these experiments is presented in section 4 . The Conclusion is in section 5 .

\section{Magnet moving model}

Figure 2 is a diagram of that part of the loop (big circle) which has an effect on the magnet (small circle).

The inverse experiment of Ampere's Circuit Law is to have the magnet moving through the loops of the solenoid to induce a voltage in the solenoid.

\section{Experiment}

(All measurement are $\pm 10 \%$ unless otherwise stated).

A solenoid was formed with 60 turns of 22 AWG wire with a diameter of 16 $\mathrm{cm}\left(D_{\mathrm{c}}=8 \mathrm{~cm}\right)$ and a height of $9.8 \mathrm{~cm}$. Disc magnets $(16 \mathrm{~mm}$ wide $\mathrm{X} 5 \mathrm{~mm}$ thick) are assembled into a column $5 \mathrm{~cm}$ long ("bar magnet"). The bar magnet is dropped through the solenoid and the induced voltage is measured with a voltmeter placed across the leads of the solenoid.

The magnet was first dropped from a height of $\approx 30 \mathrm{~cm}$ through the center $\left(D_{\mathrm{m}}=0\right)$ several times. The maximum voltage $V_{\max }\left(D_{\mathrm{m}} \approx 0 \mathrm{~cm}\right)=0.12 \mathrm{v}$ was measured. Next, the magnet was dropped from a height of $\approx 30 \mathrm{~cm}$ near the edge of the solenoid several times and the maximum voltage $V_{\max }\left(D_{\mathrm{m}} \approx 6 \mathrm{~cm}\right)=0.12$ $\mathrm{v}$ was measured. Unlike when current moves in the wires, the moving magnet induces a current in the whole solenoid.

\section{Interpretation}

The comparison of this experiment with the experiment of Hodge (2018c) shows the asymmetry of the measurements near the edge of the solenoid relative to the center measurements. The difference, according to the STOE, is that the Maxwell's Equations are not symmetrical.

There appear to be two different forms of magnetic intensity $(B)$. One is the magnetic intensity $B_{\mathrm{h}}$ of the density of hods, each hod having a $\rho$ density of the magnetic poles. The other $B_{\mathrm{p}}$ of the plenum caused by the accumulation of the particles' plenum field. Each has a unique characteristic. The $B_{\mathrm{h}}$ has the $\delta$ distribution character. The $B_{\mathrm{p}}$ has the character of a plenum field.

Likewise, the electric intensity has the character of the plenum in the coulomb field in which changes propagate at many times the speed of light (de Sangro et al. 2012) and the character of particles of electrons which have a moving particle density.

Ampere's circuital law is the $B_{\mathrm{h}}$. From this the wave equation for hods is developed. The hod speed $c=\frac{1}{\sqrt{\epsilon_{0} \mu_{0}}}$. Faraday's Law of Induction uses $B_{\mathrm{p}}$ which derives the speed of a plenum wave as the speed of the coulomb field. 
The $B_{\mathrm{p}}$ is like the electric "field" being the density of plenum vortices (cones and rings) (Hodge 2018a). The hods generate vortices in the plenum as they move. The behavior of hods far from the emitting current in antennas is the study of the electromagnetic (EM) field. The description of the EM field from a dipole antenna array is the basis for the STOE model of photon diffraction. Like moving hods, the photons which are a column of hods produce waves of plenum which directs the photons in diffraction experiments (Hodge 2012, 2016)

The essence of Maxwell's Equations in the STOE is that moving particles produce plenum gradients/waves and that plenum gradients/waves produce moving particles. But classically the $B$ and $E$ are not linked and has lead to the asymmetry. Perhaps, the idea of Maxwell's Equations should be restated in terms of hods and plenum.

\section{Conclusion}

The Scalar Theory of Everything (STOE) posits the components of the universe are hods and plenum. An experiment to test Ampere's law and the STOE was performed. The data shows the STOE model is very close to the actual measurements. The results of the experiments suggest a distinction between magnetic fields caused by hods and magnetic fields caused by plenum resolves the asymmetry. 


\section{REFERENCES}

\section{References}

Hodge, J.C., 2012, Photon diffraction and interference, IntellectualArchive, Vol.1, No. 3, P. 20,. http://intellectualarchive.com/?link=item\&id $=597$

Hodge, J.C., 2015, Universe according to the STOE, http://intellectualarchive.com/?link=item\&id $=1648$

Hodge, J.C., 2016, Diffraction experiment and its STOE photon simulation program rejects wave models of light, IntellectualArchive, Vol.4, No. 6, P. 20,. http://intellectualarchive.com/?link=item\&id=1603 video: https://www.youtube.com/watch?v=OMAjKk6k6-k

Hodge, J.C. 2018a, STOE electric charge. IntellectualArchive, v.7(2), p. 1-10. http://intellectualarchive.com/?link=item\&id=1917.

Hodge, J.C. 2018b, Magnetostatics relation to gravity with experiment that rejects Biot-Savart Law. IntellectualArchive, v.7(3), p. 1-8. http://intellectualarchive.com/?link=item\&id=1945.

Hodge, J. C., 2018c, Another experiment rejects Ampere's Law and supports the STOE model. IntellectualArchive, v. 7 (4), p. 1-5. http://intellectualarchive.com/?link=item\&id=1956.

Hodge, J.C., 2018d, Theory of Everything (STOE), http://www.vixrapedia.org/wiki/Theory_of_Everything_(STOE).

de Sangro, R. et al., 2012, Measuring Propagation Speed of Coulomb Fields, https://arxiv.org/abs/1211.2913

https://wikipedia.org/wiki/Faraday\%27s_law_of_induction. 
DOI 10.32370/2018_07_6

\title{
Another experiment rejects Ampere's Law and supports the STOE model
}

\author{
J.C. Hodge ${ }^{1 *}$ \\ ${ }^{1}$ Retired, 477 Mincey Rd., Franklin, NC, 28734
}

\begin{abstract}
The Scalar Theory of Everything (STOE) posits the components of the universe emerge to cause gravity and electromagnetic effects. An experiment to test Ampere's law and the STOE was performed. The data shows the STOE model is very close to the actual measurements. The traditional magnetostatics Biot-Savart Law is rejected. The STOE model of magnetostatics is not rejected and is supported.
\end{abstract}

keywords: STOE, Theory of Everything, magnetostatics, Biot-Savart Law

\section{Introduction}

Maxwell's Equations classically describe the relationships of magnetic (B) and electric (E) fields. They are inexact and seem to not apply to situations involving individual photons.

The Scalar Theory of Everything (STOE) suggests the hods have a greater plenum density $\rho$ held at a maximum on one side and a minimum on the other side which is the magnetic effect. The magnetic field of classical physics is a cloud of hods with the same orientation. A photon is a column of hods. The density of hods is the $B$ intensity. A current of electrons in a wire ejects hods perpendicular to the wire and the current direction. An experiment rejected the Biot-Savart (Ampere's) Law and did not reject the STOE model (3). The Biot-Savart Law for a magnetic field $\vec{B}_{b}(\vec{R})$ at a position $\vec{R}$ from a element $\mathrm{d} L$ of the wire caused by a current $\vec{I}$ in the wire is

$$
\vec{B}_{b}(\vec{r})=\frac{\mu_{0}}{4 \pi} \int_{c} \frac{\vec{I} \mathrm{~d} L \times \vec{R}}{|\vec{R}|^{3}}
$$

where $\mu_{0}$ is the magnetic constant and the integration is considered to be for an infinitely long wire.

This paper demonstrates the effect of the STOE model of a current in a solenoid. The terms and development of the STOE model may be viewed at Vixrapedia and Hodge (2).

*E-mail: jchodge@frontier.com 


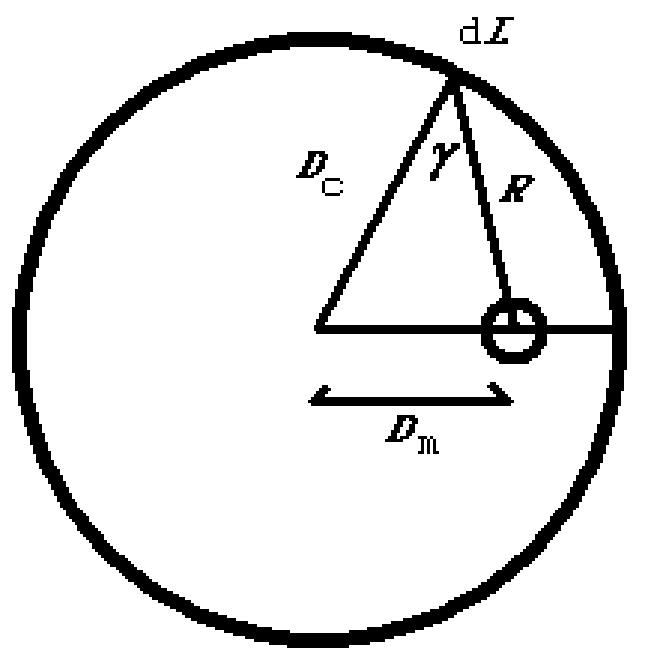

Figure 1: Diagram showing the symbols used when the small, round magnet is in a solenoid.

\section{Model}

The STOE effect of a current in a circular loop of wire is within an angle $\pm \theta$ from the radial direction from each point $\mathrm{d} L$ along the wire. Figure 1 is a diagram of that part of the loop (big circle) which has an effect on the magnet (small circle).

Hods are emitted from moving electrons with a uniform N-S (north - south) pole direction (3). As the hods travel from the emission point, their magnetic fields repel causing the hod distribution to disperse laterally and radially. The hod distribution becomes spherical. Therefore, the distribution density becomes proportional to $1 /$ distance $^{2}$. The hod distribution spreads with an angle $\theta$ from the normal to the $\vec{I} d L$.

The force $W$ on the magnet is proportional to the number of hods (density times volume) in the magnet. The magnetic $\vec{B}_{s}$ in the STOE model for each point in the magnet is

$$
\vec{B}_{s}(\vec{R})=\delta \vec{B}_{b}(\vec{R})
$$

where

$$
\begin{aligned}
\delta & =1 & \theta>\gamma \\
& =0 & \theta \leq \gamma
\end{aligned}
$$




\section{Experiment}

(All measurement are $\pm 10 \%$ unless otherwise stated).

A solenoid was formed with 60 turns of 22 AWG wire with a diameter of $16 \mathrm{~cm}\left(D_{\mathrm{c}}=8 \mathrm{~cm}\right)$ and a height of $9.8 \mathrm{~cm}$. Disc magnets ("Nexlevel super strong mini" $6 \mathrm{~mm}$ wide X $2 \mathrm{~mm}$ thick) are assembled into a column $5 \mathrm{~cm}$ long ("bar magnet"). The bar magnet is placed at the bottom plane of the solenoid and on a wood block which is place on a gram-weight (gw) scale (AWS-100, Digital scale) with a tolerance of \pm 0.02 gw. The weight measured $W$ (gw) is the difference of the meter reading without current and the meter reading with current. The absolute value of the readings with current in both directions are averaged which reflects averaging a force that increases $W$ and a force that decreases $W$.

Simplifications that make the experiment easier to analyze are the measured values at a point are compared to the measured value $W_{0}$ at the center of the solenoid, the action is considered to be at the center of the magnet, and the calculation is reduced to the plane at one end of the solenoid. The analysis was with an Excel program.

Figure 2 shows the data of $W / W_{0}$ versus the $D_{\mathrm{m}}$ and the calculated values for the STOE model. The traditional Biot-Savart Law (Ampere's Law) model suggests the entire loop affects the magnet at all positions of the magnet.

\section{Discussion and Conclusion}

The magnetic "field" according to the STOE is the density distribution of hods with the same orientation. This is like the electric "field" being the density of plenum vortices (cones and rings). The hods generate vortices in the plenum as they move. The behavior of hods far from the emitting current in antennas is the study of the electromagnetic field (EM). The description of the EM field from a dipole antenna array is the basis for the STOE model of photon diffraction.

Figure 2 shows the STOE theoretical line with a variation about the data line. This is because the theoretical calculation involved an assumption that the action is at the point in the center of the magnet. If this point is just inside the $\theta$, the whole magnet is counted. The next $\vec{I} d L$ may have the point outside the $\theta$ value and is not be counted.

The data shows the STOE model is very close to the actual measurements. The traditional magnetostatics Biot-Savart Law is rejected. The STOE model of magnetostatics is not rejected and is supported. 


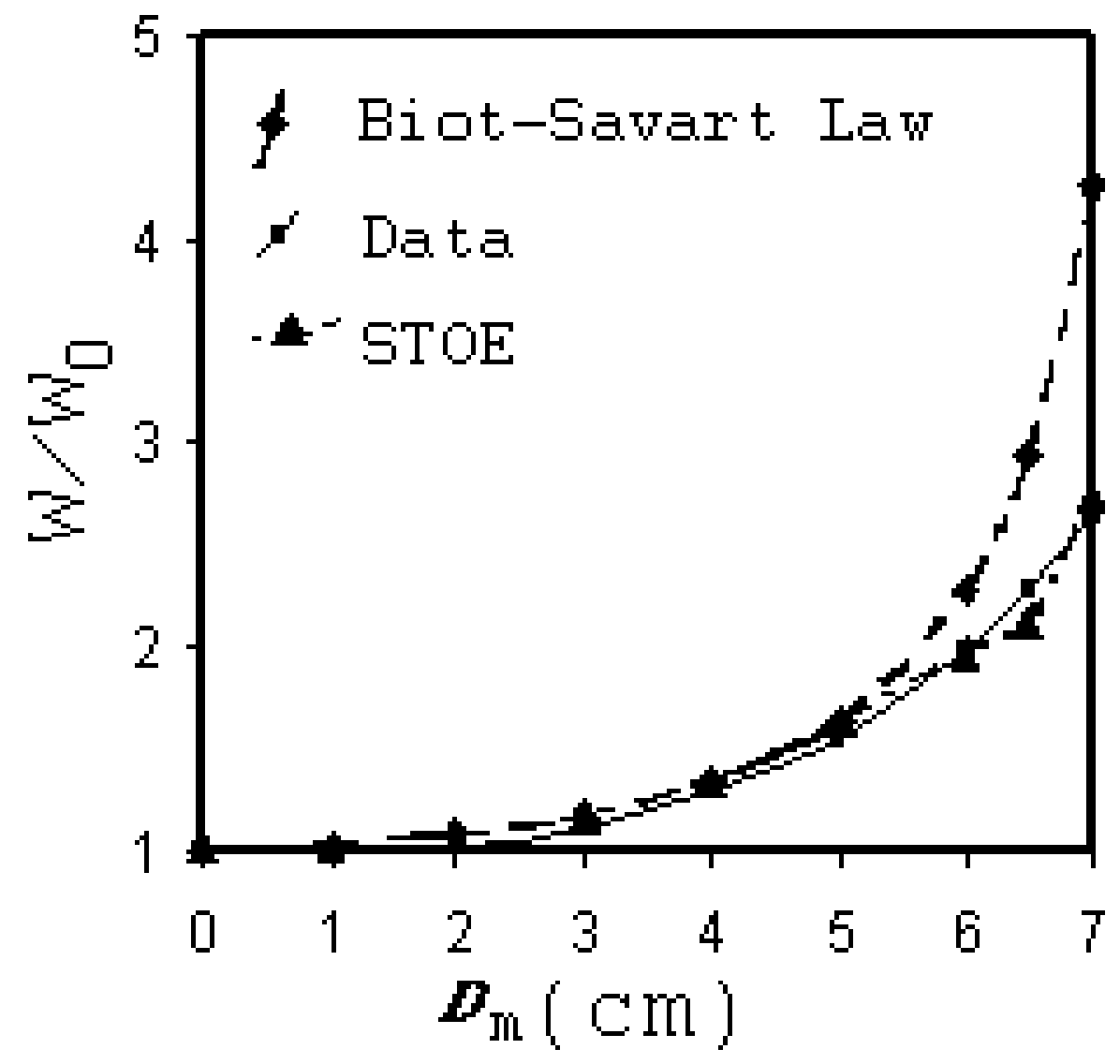

Figure 2: Measured data (solid line) and the STOE calculated data (triangles with dotted line) graph with the Biot-Savart Law calculations added. The $\theta=0.82$ radians. 


\section{REFERENCES}

\section{References}

[1] Hodge, J.C., 2012, Photon diffraction and interference, IntellectualArchive, Vol.1, No. 3, P. 20,. http://intellectualarchive.com/?link=item\&id $=597$

[2] Hodge, J.C., 2015d, Universe according to the STOE, http://intellectualarchive.com/?link=item\&id $=1648$

[3] Hodge, J.C. Magnetostatics relation to gravity with experiment that rejects Biot-Savart Law. IntellectualArchive, 2018, v.7(3), p. 1-8. http://intellectualarchive.com/?link=item\&id=1945.

[Vixrapedia] Hodge, J.C. Theory of Everything (STOE), http://www.vixrapedia.org/wiki/Theory_of_Everything_(STOE). 


\title{
Dense Spiral Packing of Circles in the Plane \\ Michael Perfileev, math research specialist, East-Siberian branch of FSUE «VNIIFTRI», Russia, Irkutsk
}

\begin{abstract}
This paper is devoted to the dense packing of the circles whose radii make up a decreasing geometric progression. It is shown that the solution to the problem of finding the denominator of this progression for such a packing reduces to the solution of the transcendental equation. That is, the problem does not have an exact solution and can only be solved approximately by applying numerical methods and computer software packages. An interesting property of such a package is considered, as well as an example of a dense spiral packing is given and solved for the case of 11 circles.
\end{abstract}

Keywords: packing problems, circle, transcendental equations, numerical methods, geometric progression, Ceva's theorem

\section{Introduction}

We consider the problem of $m$ circles tight packing ( $m$ is a number of circles and $\mathrm{m}$ $\geq 8$ ), whose radii form a geometric progression (note that the circles are on a plane). The denominator $x$ of this progression is less than one, that is, the radius of each subsequent circle is $\frac{1}{x}$ times smaller than the radius of the previous circle. Each circle, starting with the second one, touches the central circle and two adjacent circles. The last circle touches the second circle (Figure 1). We call such a packing a dense spiral packing of circles on the plane. The problem converges to finding the denominator $x$ of the decreasing geometric progression, by which it is possible to carry out such a packing for a given number of circles. 


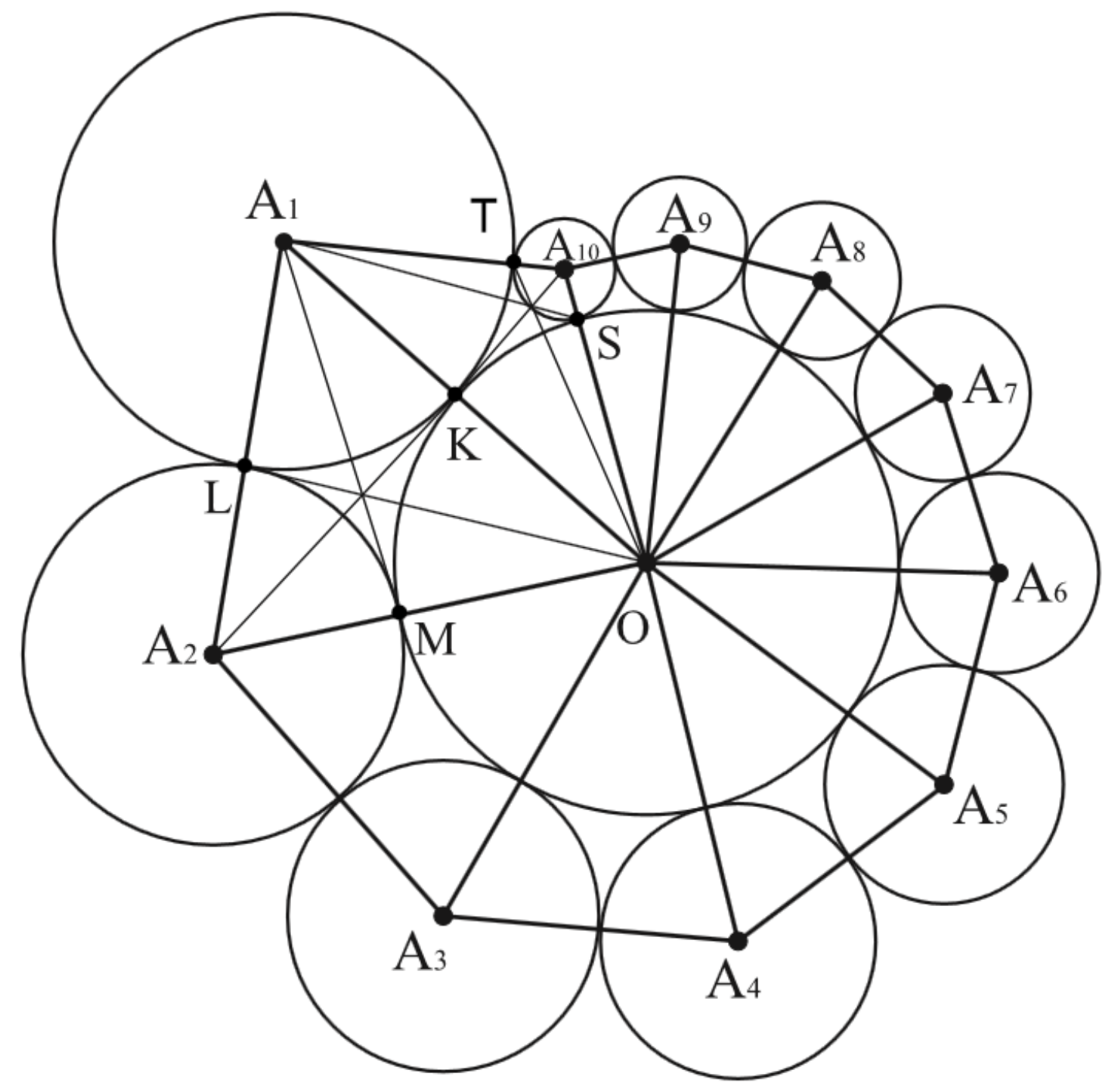

Fig. 1. Dense spiral packing of circles on a plane.

The theorem on the dense spiral packing of circles

We state and prove the following theorem:

The problem of dense spiral packing of circles on a plane is unsolvable in radicals, it does not have an exact solution, and can only be solved approximately.

Proof: 
Consider the triangles $\mathrm{O} A_{1} A_{2}, \mathrm{O}_{2} A_{3}, \ldots, \mathrm{O} A_{n-1} A_{n}$, where $n=m-1$, where $m$ is the total number of circles. We suppose that the radius of the central circle equals 1 .

The sides of the triangle $\mathrm{O} A_{1} A_{2}$ are $1+x ; x+x^{2} ; 1+x^{2}$;

The sides of triangle $\mathrm{O}_{2} A_{3}$ are equal to $1+x^{2} ; x^{2}+x^{3} ; 1+x^{3}$;

The sides of the triangle $\mathrm{O} A_{n-1} A_{n}$ are equal to $1+x^{n-1} ; x^{n-1}+x^{n} ; 1+x^{n}$. The last triangle $\mathrm{O} A_{n} A_{1}$ has sides $1+x^{n} ; x^{n}+x ; 1+x$.

The cosine theorem [1] for the triangles $\mathrm{O} A_{1} A_{2}, \mathrm{O} A_{2} A_{3}, \ldots, \mathrm{O} A_{n-1} A_{n}$ will be written in the form:

$$
\begin{aligned}
& \left(x+x^{2}\right)^{2}=(1+x)^{2}+\left(1+x^{2}\right)^{2}-2(1+x)\left(1+x^{2}\right) \cos \left(A_{1} O A_{2}\right) \\
& \left(x^{2}+x^{3}\right)^{2}=\left(1+x^{2}\right)^{2}+\left(1+x^{3}\right)^{2}-2\left(1+x^{2}\right)\left(1+x^{3}\right) \cos \left(A_{2} O A_{3}\right) \\
& \cdots \cdots \\
& \left(x^{n-1}+x^{n}\right)^{2}=\left(1+x^{n-1}\right)^{2}+\left(1+x^{n}\right)^{2}-2\left(1+x^{n-1}\right)\left(1+x^{n}\right) \cdot \\
& \cdot \cos \left(A_{n-1} O A_{n}\right)
\end{aligned}
$$

Then the angle $A_{1} O A_{2}=\arccos \left(\frac{(1+x)^{2}+\left(1+x^{2}\right)^{2}-\left(x+x^{2}\right)^{2}}{2(1+x)\left(1+x^{2}\right)}\right)$;

The angle is $A_{2} O A_{3}=\arccos \left(\frac{\left(1+x^{2}\right)^{2}+\left(1+x^{3}\right)^{2}-\left(x^{2}+x^{3}\right)^{2}}{2\left(1+x^{2}\right)\left(1+x^{3}\right)}\right)$;

The angle is $A_{n-1} O A_{n}=\arccos \left(\frac{\left(1+x^{n-1}\right)^{2}+\left(1+x^{n}\right)^{2}-\left(x^{n-1}+x^{n}\right)^{2}}{2\left(1+x^{n-1}\right)\left(1+x^{n}\right)}\right)$.

Then the sum of the angles

$$
\begin{aligned}
& A_{1} O A_{2}+A_{2} O A_{3}+\cdots+A_{n-1} O A_{n}= \\
= & \sum_{n=2}^{m-1}\left(\arccos \left(\frac{\left(1+x^{n-1}\right)^{2}+\left(1+x^{n}\right)^{2}-\left(x^{n-1}+x^{n}\right)^{2}}{2\left(1+x^{n-1}\right)\left(1+x^{n}\right)}\right)\right)
\end{aligned}
$$

For the triangle $\mathrm{O} A_{n} A_{1}$ by the cosine theorem [1]

$$
\left(x^{n}+x\right)^{2}=\left(1+x^{n}\right)^{2}+(1+x)^{2}-2\left(1+x^{n}\right)(1+x) \cos \left(A_{n} O A_{1}\right),
$$

and therefore the angle

$$
A_{n} O A_{1}=\arccos \left(\frac{\left(1+x^{n}\right)^{2}+(1+x)^{2}-\left(x^{n}+x\right)^{2}}{2\left(1+x^{n}\right)(1+x)}\right)
$$


Adding the expressions (1) and (2), we obtain the sum of all the angles $A_{1} O A_{2}+A_{2} O A_{3}+\cdots+A_{n-1} O A_{n}+A_{n} O A_{1}$, which equals to the degree measure of the total circle, that is $2 \pi$ radians:

$\sum_{n=2}^{m-1}\left(\arccos \left(\frac{\left(1+x^{n-1}\right)^{2}+\left(1+x^{n}\right)^{2}-\left(x^{n-1}+x^{n}\right)^{2}}{2\left(1+x^{n-1}\right)\left(1+x^{n}\right)}\right)\right)+\arccos \left(\frac{\left(1+x^{n}\right)^{2}+(1+x)^{2}-\left(x^{n}+x\right)^{2}}{2\left(1+x^{n}\right)(1+x)}\right)=$ $2 \pi$

Taking into account that $n=m-1$, the equation (3) takes the following form:

$\sum_{n=2}^{m-1}\left(\arccos \left(\frac{\left(1+x^{n-1}\right)^{2}+\left(1+x^{n}\right)^{2}-\left(x^{n-1}+x^{n}\right)^{2}}{2\left(1+x^{n-1}\right)\left(1+x^{n}\right)}\right)\right)+$

$\arccos \left(\frac{\left(1+x^{m-1}\right)^{2}+(1+x)^{2}-\left(x^{m-1}+x\right)^{2}}{2\left(1+x^{m-1}\right)(1+x)}\right)=2 \pi$

Performing some trivial algebraic transformations of the expression (4), we obtain a more compact equation:

$\sum_{n=2}^{m-1}\left(\arccos \left(1-\frac{2 x^{2 n-1}}{1+x^{n-1}+x^{n}+x^{2 n-1}}\right)\right)+\arccos \left(1-\frac{2 x^{m}}{1+x+x^{m-1}+x^{m}}\right)=2 \pi$

All the constituent functions of the equation (5) are analytic and not algebraic [2], [3]. Therefore, this equation is transcendental [4], [5], that is, it does not have an exact solution and can be solved only approximately with the help of numerical methods [6].

The theorem is proved.

The equation (5) can be applied in engineering, architecture and computer graphics to calculate the dense spiral packing of circles, balls, and cylinders.

The property of a tight spiral packing of circles on the plane:

In each triangle formed by the centers of pairwise tangent circles, the segments connecting the vertices of the triangle with the points of circles tangency intersect at one point.

Proof:

Consider the triangle $\mathrm{OA}_{1} \mathrm{~A}_{2}$ (Fig. 1) : $\mathrm{OK} \cdot \mathrm{A}_{1} \mathrm{~L} \cdot \mathrm{A}_{2} \mathrm{M}=1 \cdot x \cdot x^{2}=x^{3} ; \mathrm{KA} 1 \cdot \mathrm{LA} 2 \cdot \mathrm{MO}=$ $x \cdot x^{2} \cdot 1=x^{3}$. Then $\mathrm{OK} \cdot \mathrm{A}_{1} \mathrm{~L} \cdot \mathrm{A}_{2} \mathrm{M}=\mathrm{KA} 1 \cdot \mathrm{LA} 2 \cdot \mathrm{MO}$, consequently, by Ceva's theorem [7], the segments $\mathrm{A}_{1} \mathrm{M}, \mathrm{A}_{2} \mathrm{~K}$ and $\mathrm{OL}$ intersect at one point, which is what we wanted to prove. For the remaining triangles, except for the last one, the proof is similar. For 
the last triangle $\mathrm{OA}_{10 \mathrm{~A} 1}$ (using the example of a dense spiral packing of 11 circles) $\mathrm{OS} \cdot \mathrm{A} 10 \mathrm{~T} \cdot \mathrm{A} 1 \mathrm{~K}=1 \cdot x^{10} \cdot x=x^{11} ; \quad \mathrm{SA} 10 \cdot \mathrm{TA} 1 \cdot \mathrm{KO}=x^{10} \cdot x \cdot 1=x^{11}$. Hence $\mathrm{OS} \cdot \mathrm{A}_{10} \mathrm{~T} \cdot \mathrm{A}_{1} \mathrm{~K}=\mathrm{SA} 10 \cdot \mathrm{TA} 1 \cdot \mathrm{KO}$ and by Ceva's theorem [7] the segments OT, $\mathrm{A}_{1} \mathrm{~S}$ and $\mathrm{A} 10 \mathrm{~K}$ intersect at one point, which is what we had to prove.

\section{A case of a dense spiral packing with 11 circles}

For the case of 11 circles (Figure 1), the problem of their dense spiral packing reduces to the transcendental equation:

$\sum_{n=2}^{10}\left(\arccos \left(1-\frac{2 x^{2 n-1}}{1+x^{n-1}+x^{n}+x^{2 n-1}}\right)\right)+\arccos \left(1-\frac{2 x^{11}}{1+x+x^{10}+x^{11}}\right)=2 \pi$

With the help of a package of applied computer programs, it is possible to obtain an approximate numerical solution of this equation with the required accuracy (for example, 15 decimal places) $x \approx 0,860266732996342$. That is, with such a denominator of a decreasing geometric progression, the dense spiral packing of 11 circles can be realized. Then the radius of each subsequent circle will be $\approx 1,162430164557173$ times less than the radius of the previous circle. The lefthand side of the equation (6) approximately equals to 6,28318530717957401953, and it differs from the exact value $2 \pi$ by the value $\Delta \approx 10^{-14}$ : $6,28318530717957401953-2 \pi=-0,0000000000000124 \ldots \quad$ It is

noteworthy that the value $x \approx \frac{e}{\pi}: 0,860266732996342-\frac{e}{\pi}=$ $-0,0049892464 \ldots$, where $e$ and $\pi$ are Euler's number and Archimedes' constant, respectively [8].

For the case of 8 circles $x \approx 0,935652796073189 ; \frac{1}{x} \approx 1,068772523522472$; for the case of 9 circles $x \approx 0,898589160388535 ; \frac{1}{x} \approx 1,112855623105465$; for the case of 10 circles $x \approx 0,875474469382088 ; \frac{1}{x} \approx 1,142237763604691$; for the case of 1000 circles $x \approx 0,823930516998464 ; \frac{1}{x} \approx 1,213694576628801$; for 10000 circles $x \approx 0,823930516998464$; for $m \rightarrow \infty \quad x \rightarrow 0,823930516998464$. 


\section{Conclusion}

Thus, in this paper we have introduced the definition of a dense spiral packing of circles on a plane. The theorem is formulated and proved, according to which such a package is unsolvable in radicals, it does not have an exact solution, and can be solved only approximately by numerical methods. Also, the property of such a package was formulated and proved and an example of a dense spiral packing for 11 circles was shown.

\section{References}

1. Vygodsky M.Ya. Handbook of elementary mathematics. - Moscow: AST, 2008. - pp.280-282.

2. Taktarov N.G. A handbook on higher mathematics for students. - Moscow: Librocom Publishing House, 2008. - pp.409-411.

3. Ter-Krikorov A.M., Shabunin M.I. Course of mathematical analysis. - Moscow: BINOM. Laboratory of Knowledge, 2015. - pp.98-101.

4. Alexander Gelfond. Transcendental and algebraic numbers. - Moscow: ComKniga, 2006. - pp.83-93.

5. Nesterenko Yu.V. Number theory. Textbook for students of higher educational institutions. - Moscow: Academy, 2008. - pp.266-271.

6. Vladimir Formalev, Dmitry Reviznikov. Numerical methods. - Moscow: FIZMATLIT, 2006. - pp.50-69.

7. Myakishev A.G. Elements of the geometry of a triangle. - Moscow: MCNMO, 2002. - pp.5-8.

8. Steven R. Finch. Mathematical constants. Cambridge, 2003. - pp.17-28. 


\title{
Flight of Outer Solar System
}

\author{
Alexander Bolonkin \\ $C \& R$, abolonkin@gmail.com
}

\begin{abstract}
Author researches, discusses and estimates the need parameters of launch systems the mini automatic probe for flight to the nearest star systems "Alpha-Centauri" and others. He shows that problem is very difficult for current and future technology. Launch requests gigantic energy, expensive equipment and large trip time. The conventional nuclear and thermonuclear on-board reactors cannot also solve this problem (Part 1).

Author offers and researches three new possible perspective propulsion systems: multi-reflex light system used new sell-multi-reflex mirror and lasers (Part 2); cold plasma beam from Earth (Part 3) and on-board Micro Black Hole (MBH) nuclear photon rocket (Part 4). In all methods, he offered innovations, which make possible to implement all with current technology. Two first methods request the high altitude $(40 \div 80 \mathrm{~km})$ mast.

He estimates: the requested launch system (laser multi-reflect propulsion, cold plasma beam propulsion, $\mathrm{MBH}$ nuclear propulsion, etc.);grown and board equipment, energy installation (generator and accelerator); interstellar flight; environmental, medium drag; interstellar micro particles; communication with Earth. Author showed - the most realistic interstellar launch system is laser beam used the cell reflective mirror or ultra-cold plasma beam.
\end{abstract}

Keywords: interstellar launch, interstellar flight, interstellar propulsion and generator systems, laser beam, cell mirror, laser propulsion, plasma beam propulsion, photon rocket, micro black hole generator.

\section{Contents}

Introduction. Review of main problem an interstellar flight.

Part 1. Research of Space Flight in Outer Solar System.

1. Nearest Stars.

2. Efficiency from Innovation and Exploration.

3. Request Energy for Interstellar Launch.

4. Acceleration space probe by laser beam.

5. Possible Launch nuclear propulsion.

Part 2. Multi-reflex Light Launch Propulsion Systems for Space and Interstellar Flight.

1. Introduction.

2. Description of Innovation.

3. Theory (estimation) of multi-reflex light beam launch.

4. Estimation for high speed and long distance.

5. Discussing Part 2.

Part 3. Plasma Beam as Space and Interstellar Propulsion System.

1. Summary of Section 3.

2. Introduction.

3. Transfer Theory of the High Speed Neutral Ultra-Could Plasma and Particles.

4. Project of Interstellar Probe.

5. Discussing of Part 3.

6. Conclusion of Part 3.

Part 4. Converting of any Matter to Nuclear Energy and Photon Rocket for Flight outer Solar System.

1. Summary of Section 4.

2. Introduction.

3. Innovation in AB-Generator of Nuclear Energy.

4. Theory of AB-Generator. 
5. Project of AB-Generator for Photon Rockets.

6. Results.

Conclusive discussion

References

\section{Introduction \\ Review of Main Problems and interstellar flight.}

Interstellar travel is the term used for hypothetical piloted or unpiloted travel between stars. Interstellar travel will be much more difficult than interplanetary spaceflight; the distances between the planets in theSolar System are less than 30 astronomical units(AU) - whereas the distances between stars are typically hundreds of thousands of AU, and usually expressed in light-years. Because of the vastness of those distances, interstellar travel would require a high percentage of the speed of light, or huge travel time, lasting from decades to millennia or longer.

The speeds required for interstellar travel in a human lifetime far exceed what current methods of spacecraft propulsion can provide. Even with a hypothetically perfectly efficient propulsion system, the kinetic energy corresponding to those speeds is enormous by today's standards of energy production. Moreover, collisions by the spacecraft with cosmic dust and gas can produce very dangerous effects both to passengers and the spacecraft itself.

A number of strategies have been proposed to deal with these problems, ranging from giant arks that would carry entire societies and ecosystems, to microscopic space probes. Many different spacecraft propulsion systems have been proposed to give spacecraft the required speeds, including nuclear propulsion, beam-powered propulsion, and methods based on speculative physics.

In April 2016, scientists announced Breakthrough Stars hot, a Breakthrough Initiatives program, to develop a proof-of-concept fleet of small centimeter-sized sail spacecraft, named Star Chip, capable of making the journey to Alpha Centauri, the nearest extrasolar star system, at speeds of $20 \%$ and $15 \%$ of the speed of light, taking between 20 to 30 years to reach the star system, respectively, and about 4 years to notify Earth of a successful arrival.

\section{Interstellar distances.}

Because of this, distances between stars are usually expressed in light-years, defined as the distance that a ray of light travels in a year. Light in a vacuum travels around 300,000 kilometers (186,000 miles) per second, so this is some 9.46 trillion kilometers (5.87 trillion miles) or 63,241 AU in a year. Proxima Centauri is 4.243 light-years away.

Another way of understanding the vastness of interstellar distances is by scaling: one of the closest stars to the Sun, Alpha Centauri A (a Sun-like star).

\section{Required energy}

The velocity for a manned round trip of a few decades to even the nearest star is several thousand times greater than those of present space vehicles. This means that due to the $v^{2}$ term in the kinetic energy formula, millions of times as much energy is required. Accelerating one ton to one-tenth of the speed of light requires at least $450 \mathrm{PJ}$ or $4.5 \times 10^{17} \mathrm{~J}$ or 125 terawatt-hours (world energy consumption 2008 was 143,851 terawatt-hours), without factoring in efficiency of the propulsion mechanism. This energy has to be generated on-board from stored fuel, harvested from the interstellar medium, or projected over immense distances.

\section{Interstellar medium}

A thorough knowledge of the properties of the interstellar dust and gas through which the vehicle must pass will be essential for the design of any interstellar space mission. A major issue with traveling at extremely high speeds is that interstellar dust may cause considerable damage to the craft, due to the high relative speeds and large kinetic energies involved. 


\section{Travel time}

An interstellar ship would face manifold hazards found in interplanetary travel, including vacuum, radiation, weightlessness, and micrometeoroids. Even the minimum multi-year travel times to the nearest stars are beyond current manned space mission design experience.

\section{Communications}

The round-trip delay time is the minimum time between an observation by the probe and the moment the probe can receive instructions from Earth reacting to the observation. Given that information can travel no faster than the speed of light, this is for the Voyager 1 about 36 hours, and near Proxima Centauri it would be 8 years. Faster reaction would have to be programmed to be carried out automatically. Of course, in the case of a manned flight the crew can respond immediately to their observations. However, the round-trip delay time makes them not only extremely distant from, but, in terms of communication, also extremely isolated from Earth (analogous to how past long distance explorers were similarly isolated before the invention of the electrical telegraph).

Interstellar communication is still problematic - even if a probe could reach the nearest star, its ability to communicate back to Earth would be difficult given the extreme distance.

\section{Prime targets for interstellar travel}

There are 59 known stellar systems within 20 light years of the Sun, containing 81 visible stars. The following could be considered prime targets for interstellar missions:

The closest star system to Solar System is Alpha Centauri. Distance is 4.3 light year (ly). System has three stars (G2, K1, M5). Component A is similar to the Sun (a G2 star). Alpha Centauri B was thought to have one confirmed planet, but this was a false positive. The second closest star is Barnard's Star. Distance is 6 light year. One is small, low-luminosity M5 red dwarf.

\section{Propulsion system}

Rocket concepts. All rocket concepts are limited by the rocket equation, which sets the characteristic velocity available as a function of exhaust velocity and mass ratio, the ratio of initial ( $M_{0}$, including fuel) to final $\left(M_{1}\right.$, fuel depleted) mass.

Very high specific power, the ratio of thrust to total vehicle mass, is required to reach interstellar targets within sub-century time-frames. Some heat transfer is inevitable and a tremendous heating load must be adequately handled.

Thus, for interstellar rocket concepts of all technologies, a key engineering problem (seldom explicitly discussed) is limiting the heat transfer from the exhaust stream back into the vehicle. Light Beamed propulsion. The power per thrust required for a perfectly collimated output beam is $300 \mathrm{MW} / \mathrm{N}$ (half this if it can be reflected off the craft); very high energy density power sources would be required to provide reasonable thrust without unreasonable weight. The specific impulse of a photonic rocket is harder to define, since the output has no (rest) mass and is not expended fuel; if we take the momentum per inertia of the photons, the specific impulse is just $c$, which is impressive. However, considering the mass of the source of the photons, e.g., atoms undergoing nuclear fission, brings the specific impulse down to $300 \mathrm{~km} / \mathrm{s}(c / 1000)$ or less; considering the infrastructure for a reactor (some of which also scales with the amount of fuel) reduces the value further. Finally, any energy loss not through radiation that is redirected precisely to aft but is instead conducted away by engine supports, radiated in some other direction, or lost via neutrinos or so will further degrade the efficiency.

A light sail or magnetic sail powered by a massive laser or particle accelerator in the home star system could potentially reach even greater speeds than rocket- or pulse propulsion methods, because it would not need to carry its own reaction mass and therefore would only need to accelerate the craft's payload.

\section{Former interstellar Projects:}

Project Orion, manned interstellar ship (1958-1968). 
Project Daedalus, unmanned interstellar probe (1973-1978).

Starwisp, unmanned interstellar probe (1985).

Project Longshot, unmanned interstellar probe (1987-1988).

Starseed/launcher, fleet of unmanned interstellar probes (1996).

Project Valkyrie, manned interstellar ship (2009).

Project Icarus, unmanned interstellar probe (2009-2014).

Sun-diver, unmanned interstellar probe.

Breakthrough Star shot, fleet of unmanned interstellar probes, announced in April 12, 2016.

Future Micro Interstellar Project (2030-2040) .

Project Star Chip is the name used by Breakthrough Initiatives for a very small centimeter-sized, gram-scale, interstellar spacecraft envisioned for the Breakthrough Stars hot program, a proposed mission to propel a fleet of a thousand StarChips on a journey to the Alpha Centauri star system, the nearest extrasolar stars, about 4.37 light-years from Earth. The ultra-light Star Chip robotic Nano crafts, fitted with light sails, are planned to travel at speeds of $20 \%$ and $15 \%$ of the speed of light, taking between 20 to 30 years to reach the star system, respectively, and about 4 years to notify Earth of a successful arrival.

Each StarChip nano-craft is expected to carry miniaturized cameras, navigation gear, communication equipment, photon thrusters and a power supply. In addition, each nano-craft would be fitted with a meter-scale lightsail, made of lightweight materials, with a gram-scale mass.

Four sub-gram scale digital cameras, each with a minimum 2-megapixels resolution, are envisioned. Four sub-gram scale processors are planned. Four sub-gram scale photon thrusters, each minimally capable of performing at a $1 \mathrm{~W}$ diode laser level, are planned. A $150 \mathrm{mg}$ atomic battery, powered by plutonium-238 or americium-241, is planned. A coating, possibly made of beryllium copper, is planned to protect the nano-craft from dust collisions and atomic particle erosion. The light sail is envisioned to be no larger than 4 by 4 meters (13 by 13 feet), possibly of composite graphene-based material. The material would have to be very thin and, somehow, be able to reflect the laser beam without absorbing any of its thermal energy, or it will vaporize the sail.

\section{Part 1 \\ Research of Space Flight in Outer Solar System}

Reasonable humanity, men has always sought to learn about the world. An important part of his knowledge is knowledge of the universe, the search for other intelligent beings, knowledge sharing, and the extension of the Mind existence. They found that in the universe billions of solar systems. It is reasonable to assume that their planets there are other intelligent creatures with which you can establish contact and exchange of acquired knowledge.

\section{Nearest Stars}

There are 5 known stellar systems within 12 light years of the Sun, containing 7 visible stars. The following could be considered prime targets for interstellar missions:

Table 1.

\begin{tabular}{|l|l|l|} 
Stellar system & $\begin{array}{c}\text { Distance } \\
\text { (light years) }\end{array}$ & \multicolumn{1}{|c|}{ Brief Information of stellar system } \\
\hline $\begin{array}{l}\text { Alpha Centauri } \\
\text { (Three stars) }\end{array}$ & 4.3 & $\begin{array}{l}\text { Closest system. Three stars (G2, K1, M5). Component A is similar to the Sun (a G2 } \\
\text { star). Alpha Centauri B was thought to have one confirmed planet, but this was a false } \\
\text { positive. }\end{array}$ \\
\hline
\end{tabular}




\begin{tabular}{|l|l|l|}
\hline $\begin{array}{l}\text { Barnard's Star } \\
\text { (2 stars) }\end{array}$ & 6 & Small, low-luminosity M5 red dwarf. Second closest to Solar System. \\
\begin{tabular}{|l|l|} 
Sirius \\
$(2$ stars $)$
\end{tabular} & 8.7 & Large, very bright A1 star with a white dwarf companion. \\
\hline $\begin{array}{l}\text { Epsilon } \\
\text { Eridani } \\
\text { (colder Sun) }\end{array}$ & 10.8 & $\begin{array}{l}\text { Single K2 star slightly smaller and colder than the Sun. It has two asteroid belts, might } \\
\text { have a giant and one much smaller planet,and may possess a Solar-System-type } \\
\text { planetary system. }\end{array}$ \\
\hline $\begin{array}{l}\text { Tau Ceti } \\
\text { (similar Sun) }\end{array}$ & 11.8 & $\begin{array}{l}\text { Single G8 star similar to the Sun. High probability of possessing a Solar-System-type } \\
\text { planetary system: current evidence shows 5 planets with potentially two in the } \\
\text { habitable zone. }\end{array}$ \\
\hline
\end{tabular}

One light year is distance $D=c t \approx 10^{13} \mathrm{~km}$, which the light having speed $c=3 \cdot 10^{8} \mathrm{~m} / \mathrm{s}$ runs in one year $t_{1} \approx 31.45 \cdot 10^{6} \mathrm{sec}$.

The time of getting information is $T=\left(\frac{c}{v}+1\right) d$, (ly).

where Tis flight time in year; $c=3 \cdot 10^{8} \mathrm{~m} / \mathrm{s} ; v$ is probe speed, $\mathrm{m} / \mathrm{s} ; d$ is distance to star, light year

If we want to get any information in reasonable time (for example, 40 years) the relative probe speed must be $15-25 \%$ of the light speed. This is gigantic speed $v=45-75$ thousands $\mathrm{km} / \mathrm{s}$. We cannot to reach it in present time. For relative speed $v / c=0.15$ the flight time and getting information of AlphaCentauri is 33 years.

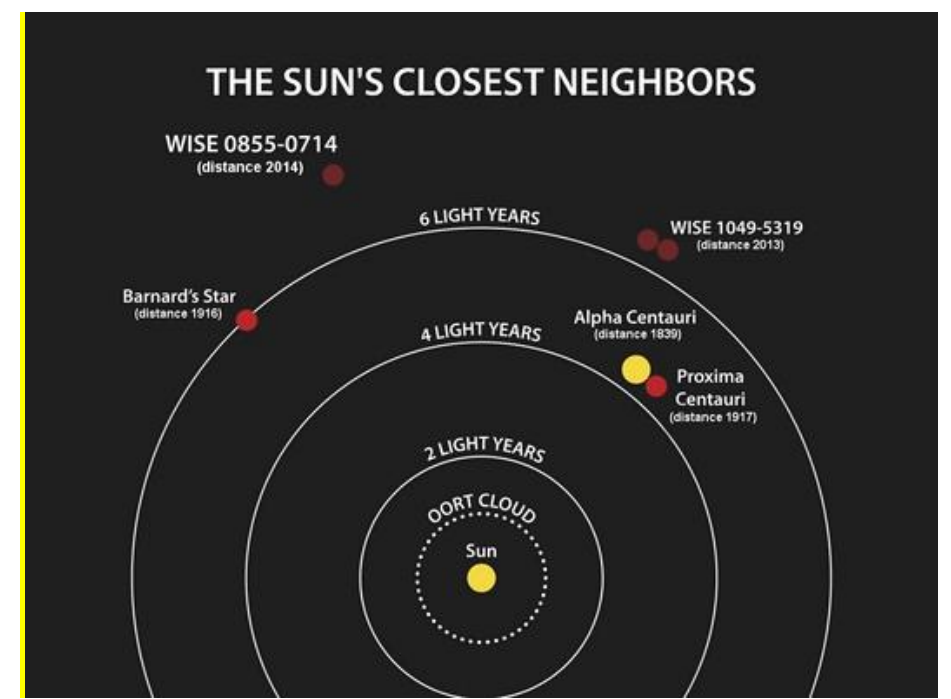

Fig.1. Stars closest to the Sun, including Alpha Centauri (25 April 2014).

What we know about the closest star system Alfa-Centauri? It consists of three stars: the pair Alpha Centauri A and Alpha Centauri B and a small and faint red dwarf, Alpha Centauri C, better known as Proxima Centauri. Alpha Centauri A ( $\alpha$ Cen A) has $110 \%$ of the mass and $151.9 \%$ the luminosity of 
the Sun, and Alpha Centauri B ( $\alpha$ Cen B) is smaller and cooler, at $90.7 \%$ of the Sun's mass and $44.5 \%$ of its visual luminosity. During the pair's 79.91-year orbit about a common center, the distance between them varies from about that between Pluto and the Sun to that between Saturn and the Sun. Proxima is at the slightly smaller distance of 1.29 parsecs or 4.24 light years from the Sun, making it the closest star to the Sun, even though it is not visible to the naked eye. The separation of Proxima from Alpha Centauri $\mathrm{AB}$ is about 0.06 parsecs, 0.2 light years or 15,000 astronomical units (AU), equivalent to 500 times the size of Neptune's orbit.

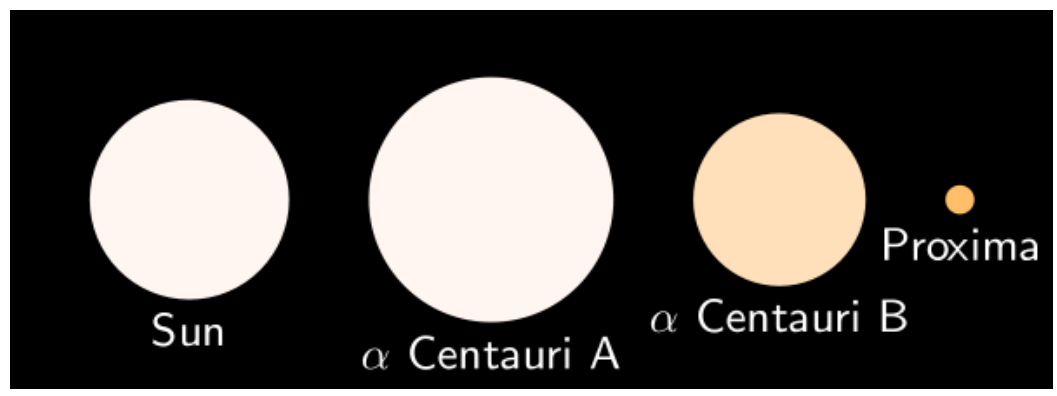

Fig.2. The relative sizes and colors of stars in the Alpha Centauri system, compared to the Sun.

Until the 1990s, technologies did not exist that could detect planets outside the Solar System. Since then, exoplanet-detection capabilities have steadily improved to the point where Earth-mass planets can be detected.

Alpha Centauri is envisioned as a likely first target for manned or unmanned interstellar exploration. Crossing the huge distance between the Sun and Alpha Centauri using current spacecraft technologies would take several millennia, though the possibility of nuclear pulse propulsion or laser light sail technology, as considered in the Breakthrough Starshot program, could reduce the journey time to a matter of decades.

\section{Efficiency from Innovations and Explorations}

The efficiency from Innovations and Explorations may be approximately estimated by equation

$$
E=P / C \text {, }
$$

where $\boldsymbol{E}$ - coefficient efficiency; $\boldsymbol{P}$ - estimation of the future profit; $\boldsymbol{C}$ - estimation of the R\&D. In given case is very difficult to estimate the efficiency of this profit for humanity. We could only estimate the gigantic expenses for R\&D of this exploration(hundreds of billions the USA dollars). The main problems are:

1. How to launch and reach very high speed?

2. What useful information the Micro-probe could get about Alfa Centauri in flight by?

3. How to pass information collected to Earth?

Let us to research some of these problems in more interesting details.

\section{Request Energy for Interstellar Launch}

Consider the simplest case of the constant acceleration:

$$
\begin{aligned}
& S=\frac{a t^{2}}{2}, \quad V=a t, \quad S=\frac{V^{2}}{2 a}, \quad a=\frac{V^{2}}{2 S}, \quad F=a m, \\
& E=F S=\frac{m V^{2}}{2}, \quad P=\frac{E}{t}, \quad N_{1}=c F .
\end{aligned}
$$

where $S$ is distance of acceleration, $\mathrm{m} ; a$ is acceleration, $\mathrm{m} / \mathrm{s}^{2} ; t$ is time of acceleration, sec; $V$ is final 
speed, $\mathrm{m} / \mathrm{s} ; F$ is force, $\mathrm{N} ; m$ is mass of probe, $\mathrm{kg} ; E$ is requested energy for acceleration, $\mathrm{J} ; P$ isneed power for acceleration, $\mathrm{W} ; N_{1}$ is need power of laser (electric station) for single (one) reflection (conventional mirror) without a mirror loss, W, for laser efficiency $0.1 ; c=3 \cdot 10^{8} \mathrm{~m} / \mathrm{s}$ is the light speed, $\mathrm{m} / \mathrm{s}$.

If we take the probe mass $m=0.01 \mathrm{~kg}$ and the final speed $V / c=0.15, V=0.45 \cdot 10^{8} \mathrm{~m} / \mathrm{s}$, the request minimal energy is about $E \approx 10^{13} \mathrm{~J}=10^{7} \mathrm{MJ}$.

The result of computation Eq. 3 for the probe mass $m=0.01 \mathrm{~kg}$ and the final speed $V / c=0.15, V$ $=0.45 \cdot 10^{8} \mathrm{~m} / \mathrm{s}$ are presented in Table 2 .

TABLE 2.

Result of computation Eq.3 for the probe mass $m=0.1 \mathrm{~kg}$ and the final speed $V / c=0.15, V=0.45 \cdot 10^{8} \mathrm{~m} / \mathrm{s}$, $g=10 \mathrm{~m} / \mathrm{s}^{2}$ via distance of acceleration.

\begin{tabular}{|l|l|l|l|l|l|l|}
\hline $\mathbf{S}, \mathbf{m}$ & $10^{5}$ & $10^{6}$ & $10^{7}$ & $10^{8}$ & $10^{9}$ & $10^{10}$ \\
\hline $\mathbf{a}=\boldsymbol{V}^{2} / \mathbf{2 S}, \mathbf{m} / \mathbf{s}^{\mathbf{2}}$ & $10^{10}$ & $10^{9}$ & $10^{8}$ & $10^{7}$ & $10^{6}$ & $10^{5}$ \\
\hline $\boldsymbol{a}, \boldsymbol{g}$ & $10^{9}$ & $10^{8}$ & $10^{7}$ & $10^{6}$ & $10^{5}$ & $10^{4}$ \\
\hline $\boldsymbol{t}=\boldsymbol{V} / \mathbf{a}, \mathbf{s e c}$ & $4.5 \cdot 10^{-3}$ & $4.5 \cdot 10^{-2}$ & $4.5 \cdot 10^{-1}$ & $4.5 \cdot 10^{0}$ & $4.5 \cdot 10^{1}$ & $4.5 \cdot 10^{2}$ \\
\hline $\boldsymbol{F}=\mathbf{m a}, \mathbf{N}$ & $10^{8}$ & $10^{7}$ & $10^{6}$ & $10^{5}$ & $10^{4}$ & $10^{3}$ \\
\hline $\boldsymbol{P}=\boldsymbol{E} / \mathbf{t}, \mathbf{W}$ & $2.2 \cdot 10^{15}$ & $2.2 \cdot 10^{14}$ & $2.2 \cdot 10^{13}$ & $2.2 \cdot 10^{12}$ & $2.2 \cdot 10^{11}$ & $2.2 \cdot 10^{10}$ \\
\hline $\boldsymbol{N}_{\mathbf{1}}=\mathbf{c F}, \mathbf{W}$ & $3 \cdot 10^{16}$ & $3 \cdot 10^{15}$ & $3 \cdot 10^{14}$ & $3 \cdot 10^{13}$ & $3 \cdot 10^{12}$ & $3 \cdot 10^{11}$ \\
\hline $\boldsymbol{N} \mathbf{1}, \mathbf{M k W}$ & $3 \cdot 10^{7}$ & $3 \cdot 10^{6}$ & $3 \cdot 10^{5}$ & $3 \cdot 10^{4}$ & $3 \cdot 10^{3}$ & $3 \cdot 10^{2}$ \\
\hline
\end{tabular}

Now the power of the powerful electric station is about $10 \mathrm{MkW}$. That means if we accelerate our probe $0.01 \mathrm{~kg}$ at distance $10 \mathrm{mln} . \mathrm{km}$ with acceleration $10^{4} \mathrm{~g}$ by laser and conventional mirror, we need in power 30 strong electric station in during $450 \mathrm{sec}=7.5$ minutes. The acceleration $10^{4} \mathrm{~g}$ has projectwle of a big gun.

But the most current lasers have efficiency about $0.02-0.06$. If in future good laser will has efficiency 0.1 , we will need in 300 powerful electric stations.

\section{Possible Launch nuclear propulsion}

1. Many people think: the nuclear propulsion can solve the space travel. That is right for travel into Solar system, but it is not correct for the interstellar flight.

Let us show it. Take the kinetic energy of mass and the speed equation of rocket in the rocket system coordinate

From $E=\frac{m W^{2}}{2}$, we have $W=\left(\frac{2 E}{m}\right)^{0.5}=E_{s}^{0.5}, \quad \Delta V=-W \ln \frac{M_{f}}{M_{0}}$,

where $E$ is energy of fuel, $\mathrm{J} ; m$ is mass of fuel, $\mathrm{kg} ; E_{\mathrm{s}}$ specific energy of fuel, $\mathrm{J} / \mathrm{kg} ; W$ - exhaust (ejection) velocity of fuel, $\mathrm{m} / \mathrm{s} ; \Delta V$ is rocket speed, $\mathrm{m} / \mathrm{s} ; M_{\mathrm{f}}$ is final mass of rocket, $M_{0}$ is initial mass of rocket.

For chemical fuel $E_{s}=(4 \div 16) \mathrm{MJ} / \mathrm{kg}$ and $W=2 \mathrm{~km} / \mathrm{s} \div 4 \mathrm{~km} / \mathrm{s}$. For typical $M_{f} / M_{0}=0.1, \ln 0.1=$ -2.3 , the rocket speed is $4 \div 9 \mathrm{~km} / \mathrm{s}$. We need in speed $45,000 \mathrm{~km} / \mathrm{s}$. Estimate the speed, which can reach the rocket having thermonuclear reactor. Consider the most perspective reaction

$$
\begin{aligned}
& D+T={ }^{4} H_{e}(3.5 \mathrm{MeV})+n(14.1 \mathrm{MeV}), \\
& 1 e V=1.6 \cdot 10^{-19} \mathrm{~J}, \quad E=17.6 \mathrm{MeV}=28.2 \cdot 10^{-13} \mathrm{~J},
\end{aligned}
$$

The energy of neutron, neutrino, gamma rays is very difficult to use because they request a big thickness(mass) of materials to absorb the neutrons or gamma rays.

Assume we can do it. The fuel mass having (5) is $m=\mu m_{n}=5 \cdot 1.67 \cdot 10^{-27}=8.35 \cdot 10^{-27} \mathrm{~kg}$. Here $\mu$ is number of nucleons take part in reaction, $m_{n}$ is mass of one nucleon. 
From Eq. (4) we get a fuel exhaust speed $W=26 \cdot 10^{3} \mathrm{~km} / \mathrm{s}$, a rocket speed (for multi-stagy rocket) $V=60 \cdot 10^{3} \mathrm{~km} / \mathrm{s}$.

We need only $V=45 \cdot 10^{3} \mathrm{~km} / \mathrm{s}$ (see above). But we cannot get the thermonuclear energy now. The installation for it (ITER) is very complex and expensive (>\$15 B), has mass many thousands tons and it will may an industrial application after 2040 year.

There is perspective proposals of the cheap small thermonuclear cumulative/impulse [8] and ultracold compression [11] reactors of mass about $100 \div 300 \mathrm{~kg}$, but they need in $\mathrm{R} \& \mathrm{D}$. There is very perspective nuclear reactorused Micro Black Hole (MBH) [10] and convert any matter to energy with $100 \%$ efficiency. But now we only hope to get MBH by Large Hadron Collider.

Fission nuclear reactors are good developed and there are a lot of space projects used them. But all projects/reactors have a large mass more some tons and their nuclear energy in 2-4 times less that fusion reaction. They not acceptable for macro space probe $(0.01 \mathrm{~kg})$ now.

There is idea transferring the energy in space in a long distance by plasma [3 - 4] or electron beam [6] . This idea needs R\&D.

There are isotope good developed energy and propulsion systems [3] Ch.17. Their summary energy may be more than fission reaction in the long times. Their main flaw is small power and uncontrollability. They may be used for correction trajectory and getting energy in long time space flight.

\section{Acceleration space probe by laser beam}

The many scientists belief the laser beam can solve this problem. They not request the launch fuel and energy in probe. The thin lightweight sail will reflect the laser beam and he light pressure will accelerate the small probe for need speed. There are a lot of research which use the Solar light for flight in Solar system.

However the author shows in previous section (Table 2) for acceleration the probe up gigantic interstellar speed 45 thousands $\mathrm{km} / \mathrm{s}$ is requested a huge energy. The laser beam isexpanding and requests a large sail and laser diameter. The beam has a maximal distance of acceleration about 10 millions $\mathrm{km}$. But this distance requests a special Continuous Wave $(\mathrm{CW})$ large laser power more $N_{1}=$ $3000 \mathrm{MW}$ for $100 \%$ efficiency (see last column in Table 2). For 10\% efficiency therequested power is ten times more. Currently the conventional continuous wave operation laser produces $3 \mathrm{~kW}$ energy, the most impulse power laser installation in the World(NIF - National Ignition Facility) has in impulseenergy $120 \mathrm{~kJ}$. NIF costs $\$ 3.5$ billion. You can estimate: how will cost the conventional launch beam laser system.

Examples of pulsed systems with high peak power:

1) $700 \mathrm{TW}\left(700 \times 10^{12} \mathrm{~W}\right)$ - National Ignition Facility, a 192-beam, 1.8-megajoule laser system adjoining a 10-meter-diameter target chamber.

2) $1.3 \mathrm{PW}\left(1.3 \times 10^{15} \mathrm{~W}\right)$ - world's most powerful laser as of 1998 , located at the Lawrence Livermore Laboratory.

\section{Part 2 \\ Multi-reflex Light Launch Propulsion Systems for Interstellar Flight}

It is well-known the solar light is pressing on any surface. In 1900 the Russian scientist P. Lebedev measured the light pressure. It was very small $4 \cdot 10^{-6} \mathrm{~Pa}$. In 1982 author offered and researched idea the reflection laser beam by special cell mirror having very high reflection for different waves [7]. That allows to increase efficiency of mirror in millions time and in millions of times increase the light pressure. He also offered the laser engine and accelerator. Later in 2004 author researched the application this idea to space launch and energy transfer for long distance $[4,5]$. 
The purpose of this work is developing and to draw attention to the revolutionary idea of light multi-reflection by cell mirror. This idea allows the design of new engines, space and air propulsion systems, energy transmission over millions of kilometers, creation of new weapons, etc. This method and the main innovations were offered by the author in 1982 in the former USSR[7]. Now the author shows the immense possibilities of this idea in many fields of engineering - astronautics, aviation, energy, optics, direct conversion of light (laser beam) energy to mechanical energy (light engine), to name a few. This part of chapter considers the multi-reflex propulsion systems for space and energy transmission over long distances in Interstellar travel.

\section{Introduction}

Brief history: The relatively conventional way to send a spacecraft on an interstellar journey is to use the solar sail [1, p.1] or a laser sail [2, p. 1]. This method is not effective because the light intensity is very low, with only one reflection. There has been a lot of research in this area and into solar sails in general.

A. Kantrowitz offered the conventional method for using a laser beam for space propulsion [3, $\mathrm{p}$. 1]. He transferred energy using laser beam to a space vehicle, converted light energy into heat and evaporated a material, then obtained thrust from the gas pressure of this evaporated material. There is much research on this method [4, p. 4] However, it is complex, has low efficiency, has limited range (divergence of the laser beam), requires special material located on board the space ship, and requires a very powerful laser.

In 1983 the author offered another method: that of using light beam energy, then the direct conversion of light energy into mechanical pressure (for an engine) or thrust (for launchers and propulsion systems) by multiple reflections [5, p. 1].

The author found only one work related to this topic, published in 2001 [6, p. 1]. However our work is very different from this. Our suggested system has several innovations which make the proposed method possible improve its parameters millions of times. The difference between our suggested system and the previous system ${ }^{16}$ is analyzed in the "Discussion" section, below.

The reflection of light is the most efficient method to use for a propulsion system. It gives the maximum possible specific impulse (light speed is $3 \cdot 10^{8} \mathrm{~m} / \mathrm{s}$ ). The system does not expend mass. However, the light intensity in full reflection is very small, about $0.6 \times 10^{-6} \mathrm{~kg} / \mathrm{kW}$. In 1983 the author suggested the idea [7] of increasing the light intensity by a multi-reflex method (multiple reflection of the light beam by special cell mirror) and he offered some innovations to dramatically decrease the losses in mirror reflection (including a cell mirror and reflection by a super-conducting material). This allows the system to make some millions of reflections and to gain some Newtons of thrust per $\mathrm{kW}$ of beam power. This allows for the design of many important devices (in particular, beam engines [7]) which convert light directly into mechanical energy and solve many problems in aviation, space, energy and energy transmission.

In the last years achievements in optic materials and lasers have decreased the losses from reflection. The author returned to this topic and made it his primary area of research. He solved the main problems: the design of a highly efficient reflector (special cell mirror), a light lock, focusing prismatic lightweight mirrors and lenses, a laser ring, and a beam transfer over very long distances (millions of $\mathrm{km}$ ) with only very small beam divergence, light storage, a beam amplifier, a modulator of light frequency, balloon suspension of mirrors, and so on [7, p. 1].

Brief information about light and light devices. A short description of electromagnetic radiation can be found in the publication [9, p. 1].A conventional mirror can reflect a maximum of 98-99\% of the incident light energy of some bands of light waves. This gives a maximum of 200-300 reflections which is not enough for propulsion systems and engines. Because the light pressure is so low (about $0.6 \cdot 10^{-6}$ $\mathrm{kg} / \mathrm{kW}$ ), we need at least a million reflections. 
There is a well-known method for increasing mirror reflection. The layers of a quarter-wave optical thickness of high and low refractive-index materials increase the reflectance. After more than 12 layers, the reflective efficiency of a dielectric mirror approaches $100 \%$, with virtually no absorption or scattering. Maximum reflectance occurs only in a region around the design wavelength. The size of the region depends on the design of the stack of multiple dielectric coatings. Outside this region the reflectance is reduced. For example, at one-half the design wavelength it falls to the level of the uncoated substrate. The dielectric mirror is also designed for use at a specific angle of incident radiation. At other angles, the performance is reduced, and the wavelength of maximum reflectance is shifted.

Unfortunately, this dielectric mirror method is not suitable for mirrors moving relative to each other as the reflected frequency is shifted slightly, and this frequency shift accumulates over multiple reflections. Also conventional mirrors tend to reflect the beam off in some other direction if the mirrors are not kept in perfect alignment to the beam. The author's proposed cell mirror reflects the beam in the same direction which is very important for decreasing the beam divergence. The small cells provide high reflectance and small absorption.

A narrow laser beam is the most suitable for a light engine and light propulsion. There are many different types of lasers with different powers (peak power up to $10^{12} \mathrm{~W}$ ), wavelength $(0.2-700 \mu \mathrm{m})$, efficiency (1\% up to about $95 \%$ ), and pulse rate (up to some thousands of impulses per second) or continuous operations. In publications in the References, the reader will find a brief description of the laser $[8, \mathrm{p} .1]$ or more detail $[9, \mathrm{p} .1]$.

At the present time we are seeing significant advances in high-power weapons-class lasers [8, $\mathrm{p}$. 1]. The laser power reaches 1 million watts.

For our computation the beam divergence is very important. The laser beam divergence ${ }^{8}$ (see 8 , pp. 1, 4) is

$$
\theta=\frac{2}{\sqrt{\pi}} \frac{\lambda}{D}=1.13 \frac{\lambda}{D}
$$

where $\theta$ is the angle of divergence [rad], $\lambda$ is the wavelength [m], and $D$ is an aperture diameter [m]. In particular, the diameter of the laser beam may be increased by an optical lens for reducing the beam divergence. The aperture diameter may be also increased by offered laser ring (Fig. 1). The reflex capacity may be improved by using a super conductive material (this idea needs additional research).

More detailed information is in publication in the references $[7-9, \mathrm{p} .1]$.

\section{Description of Innovation}

Multi-reflex launch installation of a space vehicle. In a multiple reflection propulsion system a set of tasks appear: how to increase a mirror's reflectivity, how to decrease the light dispersion (from mirror imperfections and non-parallel surfaces), how to decrease the beam divergence, how to inject the beam between the mirrors (while keeping the light between the mirrors for as long as possible), how to decrease the attenuation (a mirror, prism material, etc), how to increase the beam range, and how much force the system has.

To solve of these problems, the author proposes[7, p. 1], a special "cell mirror" which is very reflective and reflects light in the same direction from which it came, a "laser ring" which decreases the beam divergence, "light locks" which allows the light beam to enter but keep it from exiting, a "beam transfer", a "focusing prismatic thin lens“", prisms, a set of lenses, mirrors located in space, on asteroids, moons, satellites, and so on.

Cell mirrors. To achieve the maximum reflectance, reduce light absorption, and preserve beam direction the author uses special cell mirrors which have millions of small $45^{\circ}$ degree prisms $(1 \mathrm{in} \mathrm{Fig.}$ $1 \mathrm{a}, \mathrm{g})$. Cell mirror are retroreflector cells or cube corner cells. A light ray incident on a cell is returned parallel to itself after three reflections (Fig. 1g). In the mirror, provided the refractive index of the prism 
is greater than $\sqrt{2}(\cong 1.414)$, the light will be reflected by total internal reflection. The small losses may be only from prism (medium) attenuation, scattering, or due to small surface imperfections and Fresnel reflections at the entrance and exit faces. Fresnel reflections do not result losses when the beam is perpendicular to the entry surface. No entry losses occur where the beam is polarized in parallel of the entry surface or the entry surface has an anti-reflection coating with reflective index $n_{1}=\sqrt{n_{0} n_{2}}$. Here $n_{0}$, $n_{2}$ are reflective indexes of the vacuum and prism respectively. These cell mirrors turn a beam (light) exactly back at $180^{\circ}$ if the beam deviation is less $5-10^{\circ}$ from a perpendicular to the mirror surface. For incident angles greater than $\sin ^{-1}\left(n_{1} / n_{2}\right)$, no light is transmitted, an effect called total internal reflection. Here $n$ is the refractive index of the medium and the lens $(n \approx 1-4)$. Total internal reflection is used for our reflector, which contains two plates (mirrors) with a set of small corner cube prisms reflecting the beam from one side (mirror) to the other side (mirror) (Fig. 1b,c, f). Each plate can contain millions of small $(30-100 \mu \mathrm{m})$ prisms from highly efficient optic material used in optical cables [19]. For this purpose a superconductivity mirror ${ }^{5}$ may also be used.

Laser ring. The small lasers are located in a round ring (Fig. 1c). A round set of lasers allows us to increase the aperture, resulting in a smaller divergence angle $\theta$. The entering round beam ( 9 in Fig. 1a) has slip $\theta$ (or $\theta / 2$ ) to the vertical. The beam is reflected millions of times as is shown in Fig. 1b,c and creates a repulsive force $F$. This force may be very high, tens of N/kW (see the computation below) for motionless plates. In a vacuum it is limited only by the absorption $(\mathrm{dB})$ of the prism material (see below) and beam divergence. For the mobile mirror (as for a launch vehicle) the wavelength increases and beam energy decreases as the mirrors move apart.

This system [15] can be applied to a space vehicle launch on a planet that has no atmosphere and smallgravity (for example, the Moon; high gravity requires high beam power).

Light lock. The first design of light lock allows the laser beam to enter, but closes the exit of a returned ray. The beam ( 9 in Fig. 1d) of continuous laser passes through a multi-layer dielectric mirror (10 in Fig. 1d). The entering beam runs the full length between mirrors (Fig. 1b,c), reflects a million times, and enters from the other side (11 in Fig. 1d). For moving (separating) mirrors the wavelength is changed because the beam gives up energy to the moving mirrors (see computationsin section

As a result the wavelength increases $\left(\lambda_{11}>\lambda_{9}\right)$ when the distance increases, and the wavelength decreases $\left(\lambda_{11}<\lambda_{9}\right)$ when the distance decreases. The mirror (10 in Fig. 1d), is designed to pass the laser beam (9 in Fig. 1d) and to reflect back the "used" ray (11 in Fig. 1d). If the beam is not reflected by the mirror (10 in Fig. 1d), it enters into the laser and will be reflected back by the laser's internal mirror.

The second design of the light lock is shown in Fig. 1e. This contains an additional prism 12 and an impulse laser. When laser beam 13 enters the system, the additional prism 12 is pushed into the main prism 1. While the beam runs between the mirrors, the additional prism is disconnected from the main prism and the return beam 14 cannot go back in. It travels inside the reflected mirrors with a lot of reflections if the mirrors have the right focuses. The chink, 15, between the additional and main prisms may be very small, about a light wavelength ( 1 micron). A piezoelectric plate can be used to move the additional prism. below) 


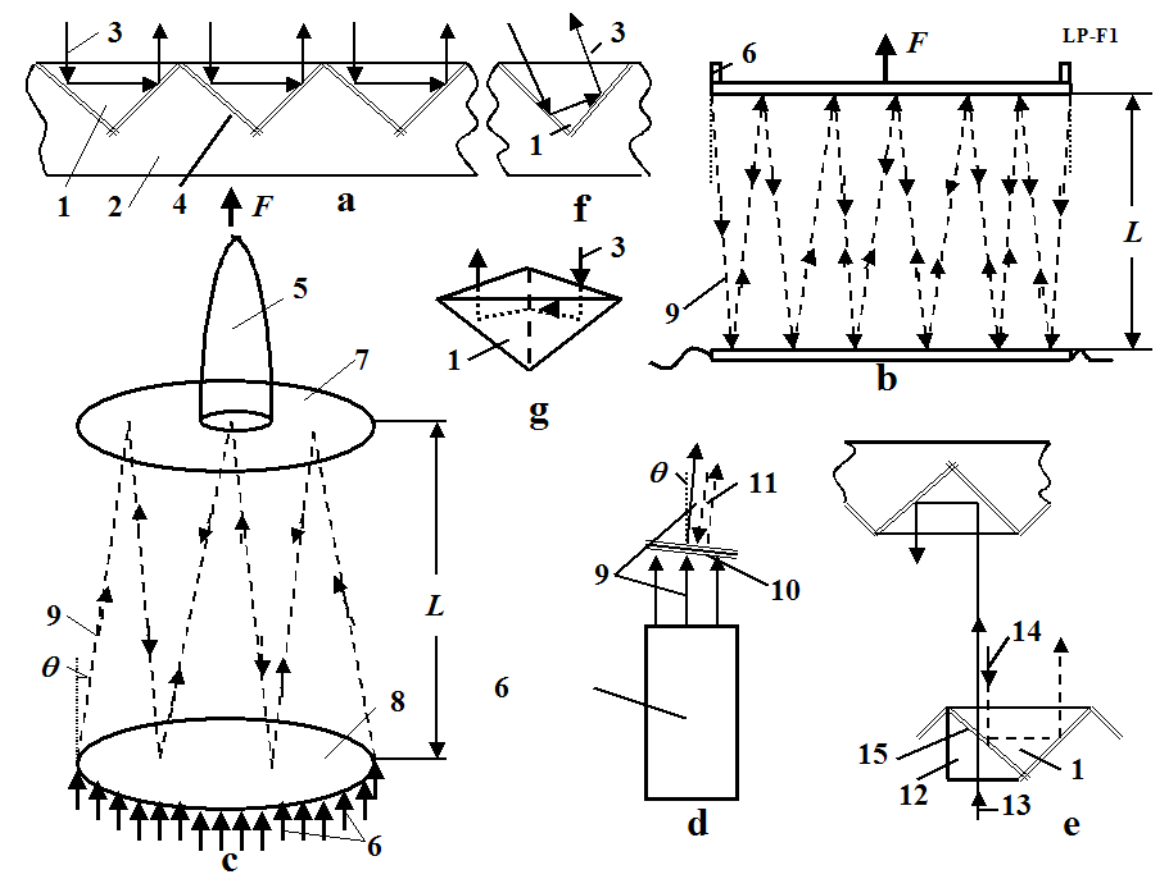

Fig. 1. Space launcher. Notations are: 1 - prism, 2 - mirror base, 3 - laser beam, 4 - mirror after chink (optional), 5 - space vehicle, 6 - lasers (ring set of lasers), 7 - vehicle (ship) mirror, 8 - planet mirror, 9 -laser beam, 10 - multi-layer dielectric mirror, 11 - laser beam after multi-reflection (wavelength $\lambda_{11}>\lambda_{9}$ ), 12 - additional prism, 13 - entry beam, 14 - return beam, 15 - variable chink between main and additional prisms. (a) Prism (cell, corner cube) reflector. (b) Beam multi-reflection, (c) Launching by multi-reflection, (d) The first design of the light lock, (e) The second design of the light lock, (f) Reflection in the same direction when the beam is not perpendicular to mirror surface, ( $\mathrm{g}$ ) Mirror cell (retroreflector cell or cube corner cell). A light ray incident on it is returned parallel to itself after three reflections.

A continuous or pulse laser may be used for the first light lock and a pulse laser may be used for the second lock. We compute average laser power.

The details of attenuation of light propagating through an optical material are considered in physics textbooks. To increase the number of reflections, we use a set of very small prisms and a highly efficient optical material $(\mathrm{dB}=0.1-0.5)$.

Space beam transfer. Space beam transfer is shown in Fig. 2a. The first lens has a large aperture for the laser beam and focuses the beam which decreases the divergence angle $\theta$. The other Fresnel's lens then continues to focus the beam (Fig. 2a).

Non-focused beam loses intensity through diffracted rays but beam transfer has a special focusing lens. If the focus is located at a distance $S_{1}=D / 2 \theta$, the beam does not have losses through up to a diffracted rays in this distance $S$, but after the distance $S$ the divergence angle becomes $2 \theta$ (Fig.2b). If we need to transmit energy a distance $L$ less than $S$ (for example, in launching), this method is fine since the distance between the mirrors $L \ll S$ and the beam is reflected many times without loss. If we want to transfer the energy over very long distance, the method shown in Fig. 2c may be better. In this method the beam is focused on point at a distance $S_{2}=D / \theta$. The beam has small amounts of diffraction everywhere, but the losses are smaller after a distance $1.5 S_{1}$ than in the case of Fig. $2 \mathrm{~b}$. If an intermediate lens with a much larger diameter than the initial lens (Fig. 2b,c) is added midway, it is possible to decreases the beam diffraction energy losses to a very small value. 


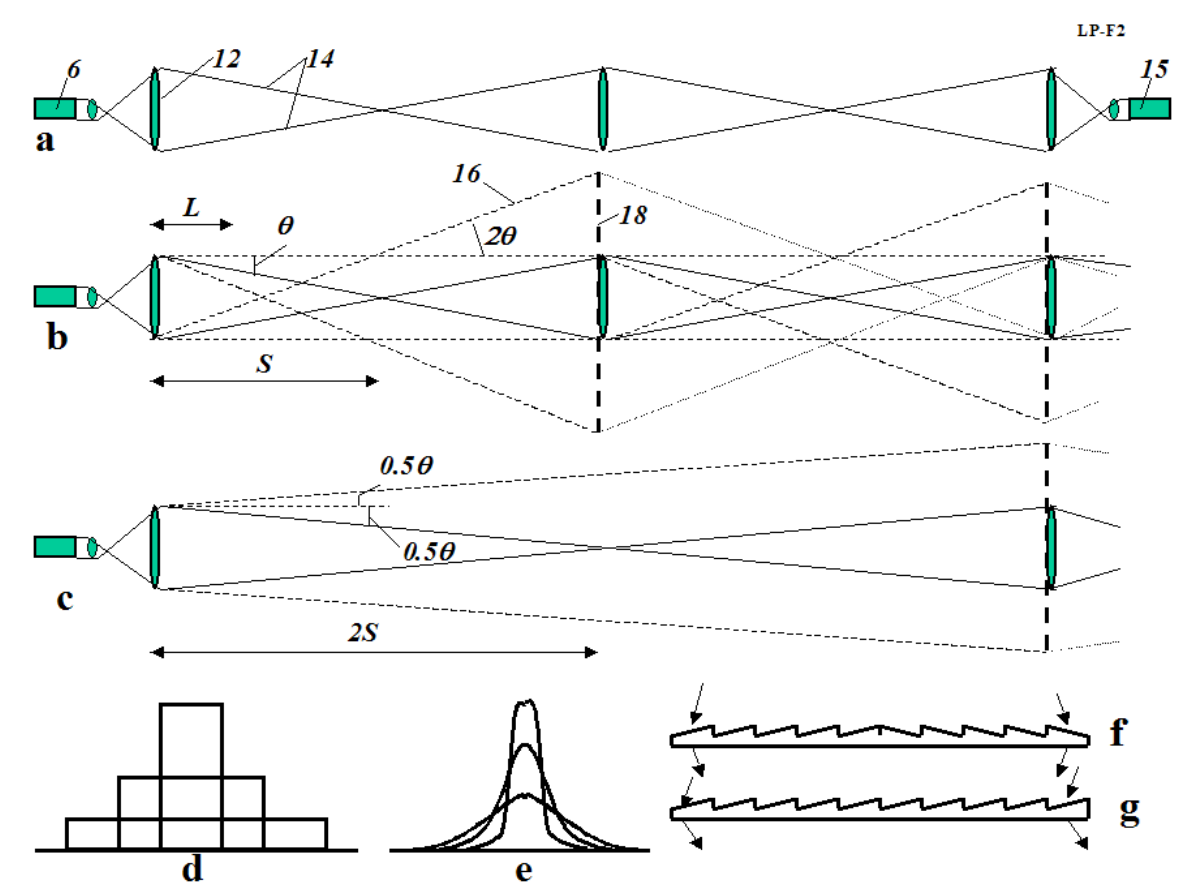

Fig. 2. Laser beam long-distance transfer. Notations are: 12 - lens, 14 - bounds of laser rays, 15 - light receiver, 16 - divergence ray. (a) focused beam, (b) focused beam with angle $\theta$ which has part $S$ without divergence,(c) focused beam with angle $0.5 \theta$ which has minimum divergence at a long distance, (d) beam with a plate wave front, (e) Gaussian beam with normal distribution of beam front, (f) Fresnel's (prism) lens, (g) lens for changing the beam direction.

The distribution of energy in a gross section area of the beam is also important for divergence and diffraction losses. The plate front (Fig. 2a) of the wave and plate distribution of energy and divergence (Fig. 2d) are worst and give the maximum of energy losses. A normal distribution of beam energy and a Gaussian beam is better because the losses of beam energy trough diffraction are reduces at the edges (Fig. 2e).

Energy transfer is done in the following way. First the Fresnel's lenses (collimators) (Fig. 2f), Fresnel's prisms (Fig. 2g), and mirrors are (permanently) located in space (Fig. 3a). Their trajectories and the receiving space vehicle's trajectory in space are known. Through commands from Earth, a space ship or the vehicle's computer, the mirrors and lenses are turned to the required angles (angular position). A small pilot ray may be used for aiming and focusing. The required angular changes are small (for focusing and small corrections in direction) and may be made by piezoelectric controlled plates. After the pilot ray reaches the space vehicle as required, the full power beam is transmitted to the space vehicle. This beam may be used to launch vehicles from an asteroid or small mass planetary satellites (Fig, 1c), to change the vehicle's trajectory (Fig, 3b), or to increase the acceleration of the space vehicle near an asteroid (Fig. 3c) using the multi-reflex method (Fig. 3a,b,c). This beam energy may be also used by the space vehicle for its rocket engine and internal power requirements. The distance between lenses may reach tens of millions of kilometers (see computation below). The average distances of the nearest planets from the Sun are: Venus $108 \times 10^{6} \mathrm{~km}$, Earth $150 \times 10^{6} \mathrm{~km}$, Mars $228 \times 10^{6} \mathrm{~km}$. Transfer efficiency of system may be about $0.7-0.9$ (see computation below). 


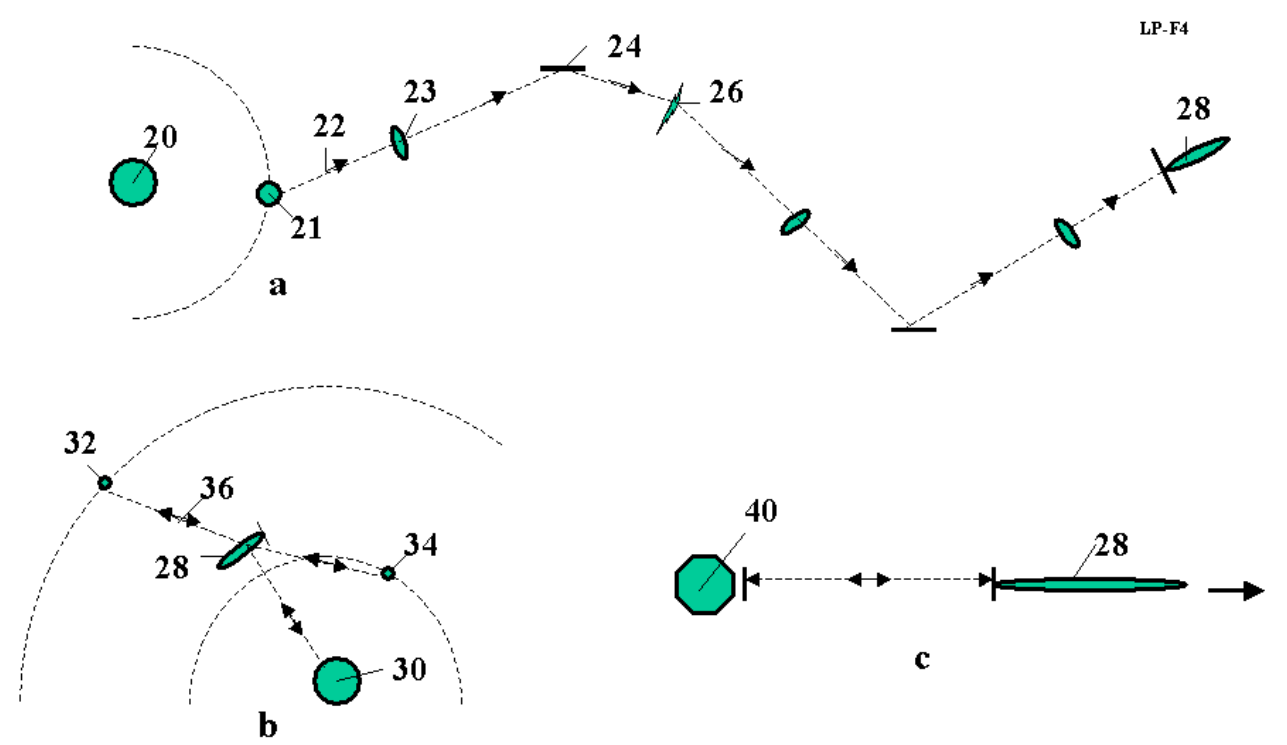

Fig. 3. Space energy transfer over long distance. a. Transferring thrust from Earth to space ship by laser beam, b. Using of satellites (or moons) to change the vehicle's trajectory, c. Using of asteroid for launching of ship. Notations are: 20 - Sun, 21 - Earth, 22 - laser beam, 23 - Fresnel's lens, 24 - mirror, 26 - Fresnel's prism, 28 - Space vehicle, 30 - planet, 32, 34 - planet satellite, 36 - multi-reflection, 40 - asteroid.

\section{Theory (Estimation) of Multi-Reflex Launching and Light Beam Transfer}

Special theory, methods and computation for this case are developed below.

Attenuation of beam. The attenuation of light passingpropagating through an optical material is caused either by absorption or by scattering. In both absorption and scattering, the power is lost over a distance, $z$, from the power $N(z)$, propagating at that point. So we expect an exponential decay:

$$
N(z)=N(0) \exp (-y z) \text {. }
$$

The attenuation coefficient, $y$, is normally expressed in $\mathrm{dB} \mathrm{km} \mathrm{km}^{-1}$, with $1 \mathrm{~dB} \mathrm{~km}^{-1}$ being the equivalent of $2.3 \times 10^{-4} \mathrm{~m}^{-1}$. Absorption is a material property in which the optical energy is normally converted into heat. In scattering processes, some of the optical power in the guided modes is radiated out of the material.

Attenuation in some current and some potential very low loss materials that have been created for fiber communication has a dB value of up to $a=0.0001\left({ }^{17}\right.$, Fig. 4).

We use in our computation conventional values of 0.1 to $0.4 \mathrm{~dB} / \mathrm{km}$. Clean air has $\xi=0.333 \times 10^{-6} \mathrm{~m}^{-1}$. The conventional optical matter widely produced currently in industry has an attenuation coefficient equals to $2 \mathrm{~dB}$. 


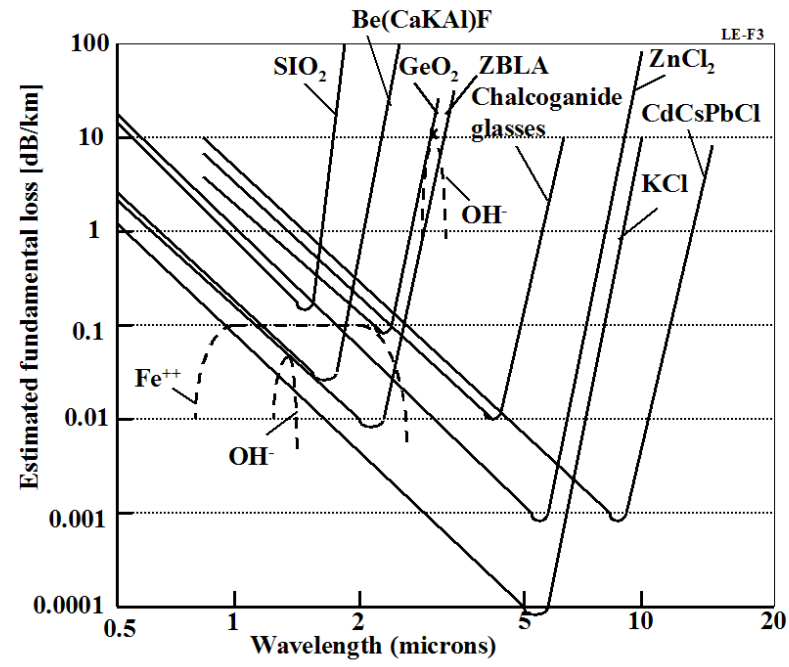

Fig.4. The estimation of basic attenuation of some possible very low loss materials.

However, some of these materials are highly reactive chemically and are mechanically unsuitable for drawing into a fiber. Some are used as infrared light guides, none are presently used for optical communication, but may be useful for our purposes. Our mechanical property and wavelength requirements are less stringent than for optical communications. We use in our computation $a=0.1-0.4$ $\mathrm{dB} \mathrm{km} \mathrm{km}^{-1}$. The conventional optical material widely produced by industry for optical cable has an attenuation coefficient of $2 \mathrm{~dB} \mathrm{~km}^{-1}$.

Change in beam power. The beam power will be reduced if one (or both) reflector is moved, because the wavelength changes. The total relative loss of the beam energy in one double cycle (when the light ray is moved to the reflector and back) is

$$
q=1-(1-2 \gamma)(1-2 \xi)(1 \pm 2 v) \varsigma,
$$

where $v=V / c, V$ is the relative speed of the mirrors $[\mathrm{m} / \mathrm{s}], c=3 \times 10^{8} \mathrm{~m} / \mathrm{s}$ is the speed of light. We take the "+" when the distance is reduces (braking) and take "- "when the distance is increased (as in launching, a useful work for light), $\gamma$ is the light loss through prism attenuation, $\xi$ is the loss (attenuation) in the medium (air) (in clean air $\xi=0.333 \times 10^{-6} \mathrm{~m}^{-1}$ ), $v$ is the loss (useful work) through relative mirror (lens) movement, $\varsigma$ is the loss through divergence and diffraction.

Multi-reflex light pressure. The light pressure, $T$, of two opposed high reflectors after a series ofreflections, $n$, to one another is

$T_{0}=\frac{2 N_{0}}{c}, \quad T_{1}=\frac{2 N_{0}}{c} q, \quad T_{2}=\frac{2 N_{0}}{c} q^{2}, \quad T_{3}=\frac{2 N_{0}}{c} q^{3}, \quad \ldots \quad, \quad T_{n-1}=\frac{2 N_{0}}{c} q^{n}$.

When $q=$ const, this is a geometric series. The sum of $n$ members of the geometric series is

$T=\frac{2 N_{0}}{c} \frac{1-q^{n}}{1-q}$. If $n=\infty$, then $T_{\infty}=\frac{2 N_{0}}{c} \frac{1}{1-q}, q<1$.

Coefficient of efficiency. The efficiency coefficient, $\eta$, may be computed using the equation

$$
\eta=T V / N_{0},
$$

Focusing the beam. If the lens used in focused at a range $S_{1}$, the distance, $S$, without ray divergence is (Fig. 2.2b):

$$
S=\frac{D}{2 \theta}, \quad \theta=\frac{2}{\sqrt{\pi}} \frac{\lambda}{D}, \quad S=\frac{\sqrt{\pi}}{4} \frac{D^{2}}{\lambda}=0.443 \frac{D^{2}}{\lambda} .
$$

Here, $D$ is the diameter of the lens or mirror [m]. This distance is equal to the lens focus distance for the case in Fig. 2.2b $\left(S_{1}=S\right)$. In the case Fig. 2c (transfer over very long distance), the optimal focus distance is $S_{2}=2 S_{1}$. 
Some computations. The computation of equation (9) is presented in Figs. 5 and 6. As you will see, the necessary focus distance may be high.

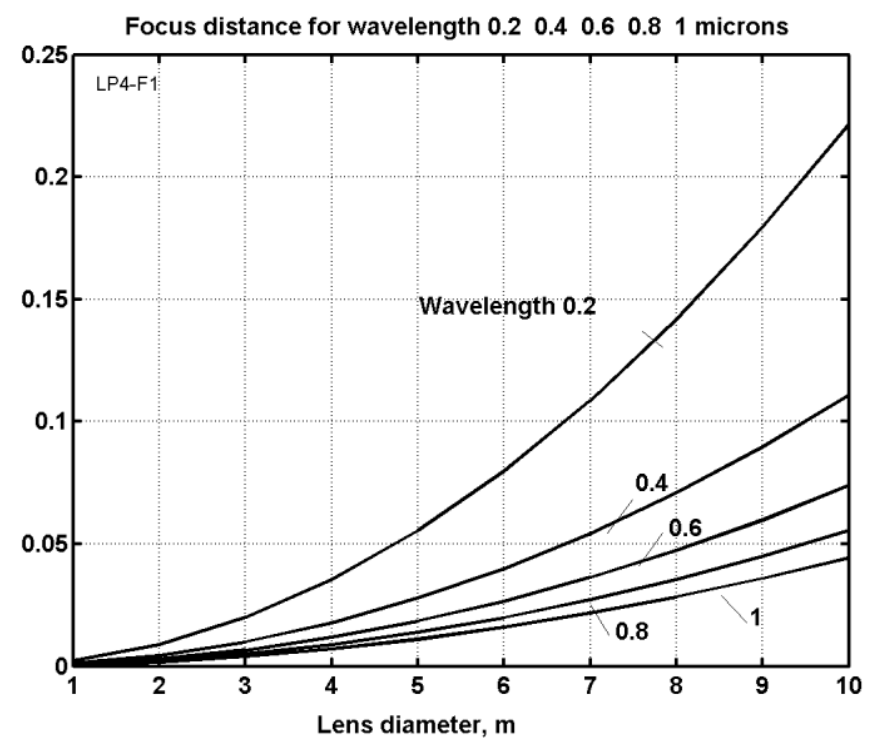

Fig. 5. Focus distances $\left[10^{6} \mathrm{~km}\right.$, million $\left.\mathrm{km}\right]$ versus lens diameters $1-10 \mathrm{~m}$ and wavelength $\lambda=0.2-1$ microns.

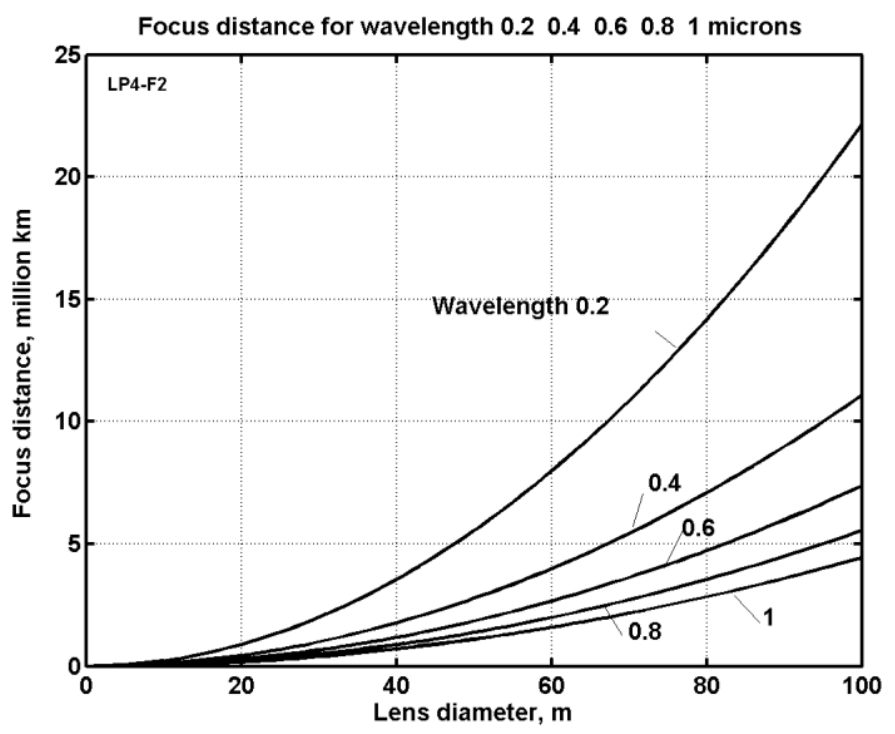

Fig. 6. Focus distances versus lens diameters $D=1-100 \mathrm{~m}$ and wavelength $\lambda=0.2-1$ microns.

The values in equation (3) can be computed as

$$
\gamma=y z=0.00023 a l, \quad l=m \lambda, \quad m \geq 1, \quad \xi=0.333 \cdot 10^{-6} L,
$$

where $a$ is the attenuation coefficient in $\mathrm{dB}\left[\mathrm{km}^{-1}\right]$ ( ${ }^{7}$, fig.4), $m$ is initial value of the wavelength which can be located in cell size $l[\mathrm{~m}]$.

The loss through divergence, $s$, for the case in Fig. $2 \mathrm{~b}, \mathrm{~d}$ is

$$
\begin{aligned}
& \varsigma=\frac{\pi(D / 2)^{2}}{\pi(D / 2+2 \gamma(L-S))^{2}}, \quad 2 \gamma(L-S)=\frac{4 k}{\sqrt{\pi}} \frac{\lambda(L-S)}{D}, \\
& \varsigma=1 /\left(1+\frac{8 k \lambda(L-S)}{\sqrt{\pi} D^{2}}\right)^{2} \text { for } L>S .
\end{aligned}
$$

Here $L$ is the distance between the mirrors (lenses) [m], and, $k$ is the focus coefficient. In case in Fig. $2 \mathrm{~b}$ (where the focus distance is $D / 2 \theta$ ) $k=0$ when $L<S$ (for transfer)or $n<S / L$ (for reflection) and 
$k=2$ when $L>S$, or $n>S / L$; in the case in Fig. 2 c ( $S$ is absent, $S=0) k=0.5$ if the focus distance is $D / \theta ; k=1$ if focus distance is infinity (no focusing).

The relative beam power along its trajectory for plate power distribution as in Fig. $2 \mathrm{~d}$ is

$$
\bar{N}=N / N_{0}=1 \text { when } L \leq S_{1} \text { and } \bar{N}=\varsigma \text { when } L>S_{1}=D / 2 \theta \text {. }
$$

The force coefficient, $A$, shows how many times the initial light pressure is increased. For $L<S_{1}$ it is

$$
A=\frac{1-q^{n}}{1-q} .
$$

The multi-reflex launch of a space vehicle from a small planet with low gravity, are without an atmosphere (the Moon or an asteroid) may be computed using the following equations (for focusing Fig. $2 \mathrm{~b}$ and beam distributions Fig. 2d):

$$
\begin{gathered}
T=\frac{2 N_{0}}{c} \frac{q^{n_{1}}-1}{q-1}+\frac{2 N_{0}}{c} q^{n_{1}} \frac{q_{1}^{n_{2}}-1}{q_{1}-1}, \quad n_{1}=\frac{S_{1}}{L}, \quad n_{2}=n_{1}-n_{3}, \quad n_{3}=\frac{\ln m}{2 v}, \quad q=1-(1-2 \gamma)(1-2 v), \\
q_{1}=q \varsigma, \quad \Delta V=\left(\frac{T}{M}-g\right) \Delta t, \quad V_{i+1}=V_{i_{i}}+\Delta V, \quad \Delta L=V_{i} \Delta t . \quad L_{i+1}=L_{i}+\Delta L, \quad t_{i+1}=t_{i}+\Delta t .
\end{gathered}
$$

Here the first element in $T$ is the thrust when the beam runs the distance $S_{1}$ without divergence. The second element in $T$ is the thrust when the beam runs the distance with divergence. $M$ is space vehicle mass $[\mathrm{kg}], g$ is the planet's gravity $\left[\mathrm{m} / \mathrm{s}^{2}\right]$. When $n_{3}<n_{1}$, we take $n=n_{3}$ and compute $T$ using equation (2.5). If $n_{3}>n_{1}$, we compute $T$ using equation (14).

Computations of the efficiency co-efficient, $\eta$, equation (8) are presented in Fig. 7.

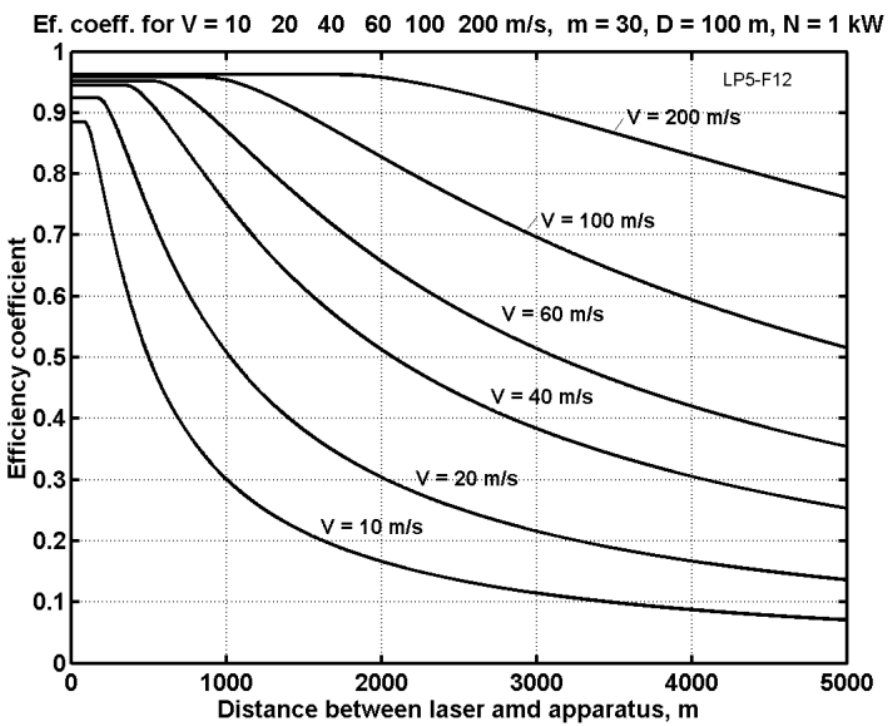

Fig.7. Efficiency coefficient versus distance [m] for vehicle speed $V=10-200 \mathrm{~m} / \mathrm{s}$, attenuation coefficient $a=$ $0.5 \mathrm{~dB}$, cell size $m=30$, mirror diameter $D=100 \mathrm{~m}$, beam power $N=1 \mathrm{~kW}$.

The thrust and the efficiency coefficient decrease when the distance is above some critical value, then a portion of the energy beam leaves the space between the mirrors through diffraction.

The mirror diameter is large because small mirror diameters decrease the attainable speed. Starting from an asteroid or a planet's moon that has low gravity, improves the attainable speed.Unfortunately, the multi-reflex launch from planets with an atmosphere does not wart well because the multi-reflected rays travel long distances in a gas medium and lose a lot of energy. 
Below is the equation for computing the beam power from the divergence and distance when the Gaussian beam has normal distribution (Fig. 2f): For case 1 (the focus is into point $2 S_{1}$, Fig. 2c)

$$
\bar{N}_{1}=2 \psi\left[s\left(\frac{D}{D+\theta L}\right)^{2}\right], \quad \theta=\frac{2}{\sqrt{\pi}} \frac{\lambda}{D}, \quad S=0 .
$$

Here $\psi$ is the probability function of normal distribution.

For case 2 (the focus is located at point $S$, Fig. 2b)

$$
\text { When } L \leq S_{1}, \quad \bar{N}_{2}=1 \text {. When } L>S_{1} \quad \bar{N}_{2}=2 \psi\left[s\left(\frac{D}{D+4 \theta\left(L-S_{1}\right)}\right)^{2}\right] \text {. }
$$

Here $s$ is a relative distribution value. The results of computations for space (vacuum) are presented in Fig. 8. It is shown that the focused beam travels without major losses if the distance between the mirrors (for mirror diameter $D=100-200 \mathrm{~m}$ ) is 10-18 million kilometers, and may travel up to 100 million $\mathrm{km}$ with an efficiency of about 0.2. This means the focused beam can permanently transfer (without losses) energy from the Earth to the Moon or back (a distance of $0.4 \times 10^{6} \mathrm{~km}$ ), and for 2-3 months (with efficiency 0.2 ) every two years, to Mars at a distance of $60-150 \times 10^{6} \mathrm{~km}$.

For computation of the relative beam power in air at altitude $H$, we may use equations (15) and (16) corrected for air attenuation. That is

$$
\bar{N}_{a 1}=\bar{N}_{1}(1-b), \quad \bar{N}_{a 2}=\bar{N}_{2}(1-b), \text { where } b=0.334 \cdot 10^{-6} \frac{\rho_{H}}{\rho_{0}} L .
$$

Here $\rho_{H}, \rho_{\mathrm{o}}$ are the air density at altitudes $H$ and $H=0$ respectively.

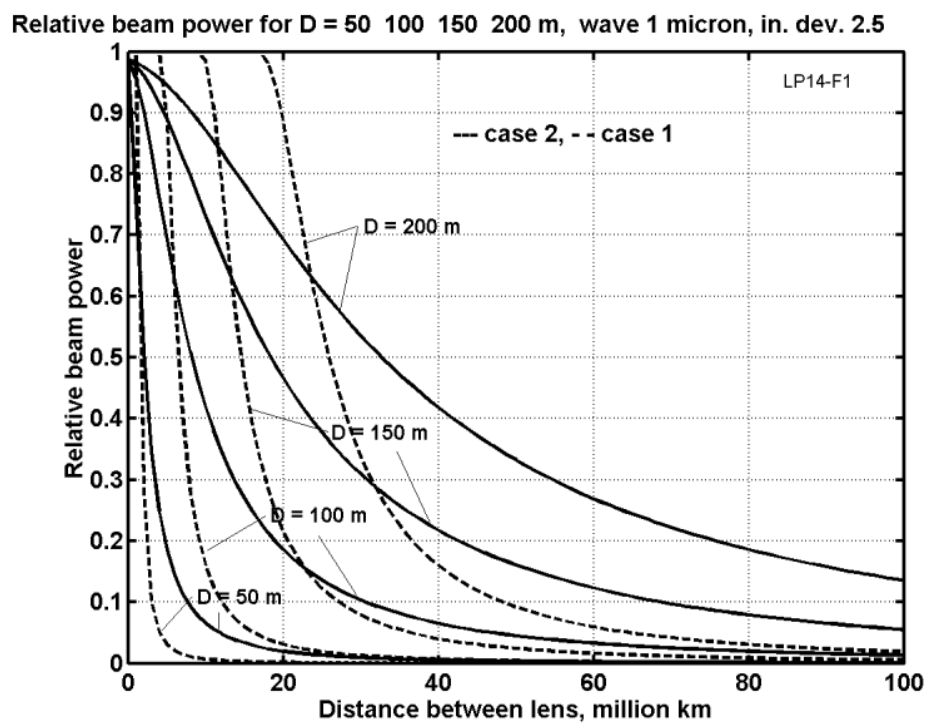

Fig. 8. Relative beam power of the normal (Gaussian) distribution $(s=\sigma=2.5)$ (Fig. 2f) in a vacuum versus distance in million kilometers between lenses for focusing at $D / 2 \theta(--$, case 1$)$ and $D / \theta(-$, case 2$)$.

The computed parameters are not optimal. Our purpose is to demonstrate the method of computation.

Computations (Fig. 7 and 8) are made for a beam power $N_{0}=1 \mathrm{~kW}$. For beam power $N_{0}=10$, 100, $1000 \mathrm{~kW}$ we must multiply the force in Figs. 2.7 and 2.8 by 10, 100, and 1000 respectively.

\section{Estimations for high speed and long distance}

\section{Maximal decreasing of request energy from multi-reflexing the light-beam.}

As we have seen in Table 2 the requested energy (power) for acceleration relativistic probe is very high. 
Multi-reflexing allowssignificantly decrease it. Let us separately estimate lossand benefits (increasing the thrust from multi-reflection) from cell mirror in atmosphere, spaceandfrom material of the mirror cell.

a) Loss energy in Earth atmosphere. It is known in clean atmosphere on Earth surface, the light beam losses the part of energy $\xi=0.333 \cdot 10^{-6} \quad 1 / \mathrm{m}$. The Earth atmosphere has the pressure $p=10^{4}$ $\mathrm{kg} / \mathrm{m}^{2}$ and density $\rho=1.225 \mathrm{~kg} / \mathrm{m}^{3}$ (on Earth surface). If Earth atmosphere has constant density its thickness is $H=p / \rho=10^{4} / 1.225=8,163 \mathrm{~m} \approx 8.2 \mathrm{~km}$. The laser instalation may locate on area/altitude 2 $\mathrm{km}$ (mountain up $4 \mathrm{~km}$, or the light beam will passed in vacuum tube of artificial tower/mast up $10-60$ $\mathrm{km})$.

If we take the altitude $5 \mathrm{~km}$, the rest altitude will be about $8-5=3 \mathrm{~km}$. The loss will be $\xi=0.333 \cdot 10^{-6} \cdot 3 \cdot 10^{3}=10^{-3} \cdot$ That means

$$
n \approx 1 / 2 \xi=1 / 2 \cdot 10^{-3}=500 .
$$

Full reflections through the Earth atmosphere or increasing the light pressure in 500 times (decreasing the request energy in 500 times!).

b) Loss energy in the cell mirror. Let us to estimate the loss energy (reflectivity) the cell mirror [Eq. 10]. Assumetheminimalwavelengthoflightis $\lambda_{0}=0.2 \mu \mathrm{m}=0.2 \cdot 10^{-6} \mathrm{~m}$, maximal wavelength is $\chi=10^{-}$ 5, $m=10^{-5} / 0.2 \cdot 10^{-6}=50$, absorption coefficient is $a=10^{-2}[\mathrm{~dB} / \mathrm{km}]=10^{-5}[\mathrm{~dB} / \mathrm{m}]$, length of cell is $l=$ $m \tau_{0}=50 \cdot 0.2 \cdot 10^{-6}=10^{-5} \mathrm{~m}$, reflectivity of cell mirror is $\gamma_{1}=a l=10^{-5} \cdot 10^{-5}=10^{-10}$. That is in hundreds of million better than conventional mirror $\left(\gamma_{1}=10^{-2}\right)$ and many thousands time more than multi-layer mirror $\left(\gamma_{1}=5 \cdot 10^{-4}\right)$. We can neglect this loss. Number of full reflection is

$$
n \approx 1 / 2 \gamma_{1}=1 / 2 \cdot 10^{-10}=5 \cdot 10^{9} \text {. }
$$

c) Loss from moving probe. Assume we want to accelerate probe up $V=8 \mathrm{~km} / \mathrm{s}$. The average speed is $V_{a}=8 / 2=4 \mathrm{~km} / \mathrm{s}$. The relative speed is $v=V_{a} / c=4 / 3 \cdot 10^{5}=1.33 \cdot 10^{-5}$. That means the number of full reflection is $n=1 / 2 v=1 / 2 \cdot 1.33 \cdot 10^{-5}=3.76 \cdot 10^{4}$. If speed of probe is high, the efficiency of cell mirror significantly decreases. In our case of interstellar probe maximal speed is $V=0.15 c=45 \cdot 10^{3}$ $\mathrm{km} / \mathrm{s}$, average relative speed is $v=0.15 / 2=0.075$. Number of full reflection is $n=1 / 2 v=1 / 2 \cdot 0.075=$ 6.67.

Conclusion: The offered cell mirror is very efficiency for intersolar launch and traveling and less efficiency for interstellar launch.

\section{Heating of reflect mirror.}

Let us estimate the heating (temperature) of mirror. The temperature of mirror is

$$
T=100\left(\frac{P_{s}}{C_{s}}\right)^{1 / 4} \text {, where } P_{s}=\frac{P \gamma_{1}}{2 s} .
$$

Here $T$ is temperature of mirror, $\mathrm{K} ; P_{s}$ is absorbed power, $\mathrm{W} / \mathrm{m}^{2} ; C_{s}=5.67 \mathrm{~W} / \mathrm{m}^{2} \mathrm{~K}^{4}$ is absorbed coefficient; $P$ is power delivered by laser to mirror, W (see Table 1); $\gamma_{1}$ is loss coefficient for one reflection; $s$ is area of mirror, $\mathrm{m}^{2}$.

Let us take the $s=5 \mathrm{~m}^{2}$, the power light beam $P=2.2 \cdot 10^{11} \mathrm{~W}$ (see last column in Table1). For cell mirror $\gamma_{1}=10^{-10}$ and $T=80 \mathrm{~K}$. For conventional mirror $\gamma_{1}=10^{-2}$ and $\mathrm{T}=8000 \mathrm{~K}$. For multi-layer mirror the best $\gamma_{1}=5 \cdot 10^{-4}$ (one wavelength) and $T=2100 \mathrm{~K}$.

As you can see only cell mirror is acceptable for interstellar probe.

3. Loss probe speed from gravity field of Earth and Sun. The probe losses speed for start from Earth surface and arriving to Earth orbit around Sun: $11.2 \mathrm{~km} / \mathrm{s}$. The probe losses speed to arriving from Earth orbit around Sun to space out the solar system: $42.1 \mathrm{~km} / \mathrm{s}$. If probe will use the Earth orbit speed (that limit the start time up $2-3$ month every year), we can save $30 \mathrm{~km} / \mathrm{s}$.In last case we loss on gravitation only $11.2+42.1-30=23.2 \mathrm{~km} / \mathrm{s}$. Radial velocity Alpha-Centauri Star A is $-21.4 \mathrm{~km} / \mathrm{s}$, star B is -18.6 $\mathrm{km} / \mathrm{s}$. All these velocities are small in comparison the requested Interstellar velocity $45000 \mathrm{~km} / \mathrm{s}$. 


\section{Interstellar flight drag of environment}

a) Shortly Information about interstellar medium. In astronomy, the interstellar medium (ISM) is the matter that exists in the space between the star systems in a galaxy. This matter includes gas in ionic, atomic, and molecular form, as well as dust and cosmic rays. It fills interstellar space and blends smoothly into the surrounding intergalactic space. The energy that occupies the same volume, in the form of electromagnetic radiation, is the interstellar radiation field.

In all phases, the interstellar medium is extremely tenuous by terrestrial standards. In cool, dense regions of the ISM, matter is primarily in molecular form, and reaches number densities of $10^{6}$ molecules per $\mathrm{cm}^{3}$ ( 1 million molecules per $\left.\mathrm{cm}^{3}\right)$. In hot, diffuse regions of the ISM, matter is primarily ionized, and the density may be as low as $10^{-4}$ ions per $\mathrm{cm}^{3}$. By mass, $99 \%$ of the ISM is gas in any form, and $1 \%$ is dust. ${ }^{[2]}$ Of the gas in the ISM, by number $91 \%$ of atoms are hydrogen and $9 \%$ are helium, with $0.1 \%$ being atoms of elements heavier than hydrogen or helium.

Stars form within the densest regions of the ISM, molecular clouds, and replenish the ISM with matter and energy through planetary nebulae, stellar winds, and supernovae. The Warm Ionized Medium (WIM) holds the 20-50\% of the interstellar volume, has scale $1000 \mathrm{pc}$, temperature about $8000 \mathrm{~K}$ and density about $0.2-0.5$ ionized atom in $\mathrm{cm}^{3}$. The Sun is currently traveling through the Local Interstellar Cloud, a denser region in the low-density Local Bubble.

b) Let us take for our estimation the interstellar density $\gamma=1 \mathrm{H} / \mathrm{cm}^{3}=10^{6} \mathrm{H} / \mathrm{m}^{3}$ (here $\mathrm{H}$ is hydrogen atom). One Light Year (ly) has time $t=31.54 \cdot 10^{6}$ seconds. Light speed is $c=3 \cdot 10^{8} \mathrm{~m} / \mathrm{s}$. Light runs in 1 ly the distance $L=c t \approx 10^{16} \mathrm{~m} / \mathrm{ly}=10^{13} \mathrm{~km} / \mathrm{ly}$. For probe speed $v=0.15 c=45 \cdot 10^{6} \mathrm{~m} / \mathrm{s}$ the number of atoms getting the $1 \mathrm{~m}^{2}$ of reflector is $N=\gamma L=10^{6} \cdot 10^{16}=10^{22}$. The mass of atoms is $m=m_{p} N=$ $1.67 \cdot 10^{-27} \cdot 10^{22}=1.67 \cdot 10^{-7} \mathrm{~kg} / \mathrm{m}^{2} \mathrm{ly}$. Energy is $E=m v^{2} / 2=1.67 \cdot 10^{8} \mathrm{~J} / \mathrm{m}^{2} \mathrm{ly}$. If the all atom will be stopped by mirror have mass $m_{\mathrm{m}}=0.01 \mathrm{~kg} / \mathrm{m}^{2}$, than the loss of speed by probe will be

$$
\Delta V \approx \frac{m v}{m_{m}}=\frac{1.67 \cdot 10^{-7} \cdot 45 \cdot 10^{6}}{10^{-2}}=750\left[\mathrm{~m} / \mathrm{s} \cdot \mathrm{m}^{2} \cdot \mathrm{ly}\right]
$$

Full probe speed loss for mirror area $s=5 \mathrm{~m}^{2}$ and 4.3 light years of flight is $\Delta V=0.75 \cdot 5 \cdot 4.3=16 \mathrm{~km} / \mathrm{s}$. It is permissible part from speed $45,000 \mathrm{~m} / \mathrm{s}$.

For breakdown of the mirror having the surface mass density $10 \mathrm{~g} / \mathrm{m}^{2}$ is enough energy $0.5 \mathrm{MeV}$ [25, p.935]. Atom of medium for speed $V=45,000 \mathrm{~km} / \mathrm{s}$ has energy about $10 \mathrm{MeV}$. That means the most of atom will fly through the mirror and loss only 5\% its energy. The loss probe speed decreases in 20 times. The density atoms in Solar system at Earth orbit is about $20 \mathrm{H} / \mathrm{cm}^{3}$. Estimation gives the loss speed of probe in Solar system about $20 \mathrm{~m} / \mathrm{s}$. We can neglect it. No problem with the interstellar atom drag.

\section{c) Problem the interstellar dust.}

Cosmic dust can be further distinguished by its astronomical location: intergalactic dust, interstellar dust, interplanetary dust.By one estimate, as much as 40,000 tons of cosmic dust reaches the Earth's surface every year.

The interstellar dust has particles $d=0.01 \div 0.2 \mu \mathrm{m}$. Mass of dust is about $1 \%$ of gas mass. Particles compose from consist of graphite, silicon carbide. Their density is about $3 \mathrm{~g} / \mathrm{cm}^{3}$. The drag from dust we neglect.

Let us to estimate the holes from dust. Take the average size of particles $0.1 \mu \mathrm{m}=10^{-7} \mathrm{~m}$, volume $10^{-21} \mathrm{~m}^{3}$, mass one particle is $m_{1}=3 \cdot 10^{-18} \mathrm{~kg}$. Total mass of particles is $M=1,67.10^{-9} \mathrm{~kg} / \mathrm{m}^{2} \mathrm{ly}(1 \%$ of gas mass). Total number of particles is $N=M / m_{1}=5.33 \cdot 10^{8} 1 / \mathrm{m}^{2}$ ly. If one particle made the hole area $s_{1}$ $=d^{2}=10^{-14} \mathrm{~m}^{2}$, the area total holearea will be approximatelys $=s_{1} N=5.33 \cdot 10^{-6} 1 / \mathrm{m}^{2} \mathrm{ly}$. In during flight time $t=4.3$ l.y. the damage will be $S=2.3 \cdot 10^{-5} 1 / \mathrm{m}^{2}$. In reality damage may be in $1-2$ order more. But we can neglect it. If interstellar drag is big, the mirror can be folded. 


\section{Discussion of Part 2 (Multi-Reflex Light Proportion System)}

Comparing the "Multi-Bounce Laser-Based Sail" system [6,P.1] with the proposed method - the "MultiReflex Propulsion System".

1. The "Multi-Bounce Sail" uses the well-known multi-layer mirror which has high reflectance only in a region around the design wavelength. Outside this region, the reflectance is reduced. For example, at one-half the design wavelength it falls to that of the uncoated substrate. As shown in this work, the wavelength changes by a small amount at each reflection in the mobile mirror. This means that after enough reflections the multi-layer mirror has lost its high reflectivity. It is impossible to use the multilayer mirror for a multi-bounce space sail that is moving. The author has proposed the innovative new cell-mirror for which the reflectivity does not depend on wavelength for wavelengths that are less than a cell length.

2. The multi-layer mirror [6, p. 1] is extremely large $\left(1 \mathrm{~km}^{2}\right)$, with extremely small thickness $(1600 \mathrm{~nm})$, density $\left(10 \mathrm{gm} / \mathrm{m}^{2}\right)$ and weight $(7850 \mathrm{~kg})$. A very small angle of deviation at the multi-layer mirror surface (one thousandth of a degree) under beam pressure, leads to complete defocusing at a distance of some millions of kilometers. This means the mirror [16] will make only one reflection. The average mirror angle will also be changed permanently for a moving space ship.

It is impossible to exactly control (turn) the orientation of this gigantic and very thin sail.

The new cell-mirror reflects the laser beam back in exactly the same direction if the surface and sail deviation are less than 5-10 degrees. This means the mirror directorial control is not necessary on the space craft. Also, there may be imperfections in the surface film and the mirror control is not necessary.

3. The maximum reflection at multi-layer mirror is 99.95 [Reference 6, p. 1]. The reflection of the cellmirror is $\left(1-0.4 \cdot 10^{-9}\right)$ or $10^{8}$ times better than the multi-layer mirror. The maximum reflection value of the multi-layer mirror is only 1000 [Reference 6, p. 1]. Value for reflections of the cell-mirror are in the millions.

4. The diameter of the multi-layer mirror is $1 \mathrm{~km}$, the size of our cell mirror is $100 \mathrm{~m}$ (for large and heavy man ships) and $2 \mathrm{~m}$ for micro probe.

5. The gigantic multi-layer solar mirror gives an acceleration of only $0.33 \mathrm{~m} / \mathrm{s}^{2}$. This is not enough to launch itself from Earth (Earth's gravity is $\left.9.8 \mathrm{~m} / \mathrm{s}^{2}\right)$, Mars $\left(3.72 \mathrm{~m} / \mathrm{s}^{2}\right)$ or the Moon $\left(1.62 \mathrm{~m} / \mathrm{s}^{2}\right)$. The author's solar cell-mirror gives an acceleration of $20 \mathrm{~m} / \mathrm{s}^{2}$ (laser up $10^{5} \mathrm{~g}$ ), and its size is 100 times smaller. If we were to made solar cell-mirror $1 \mathrm{~km}$ in diameter, the capability of a space ship would be fantastic.

The author shows here only some of the advantages of one innovation (changing from the wellknown multi-layer mirror to the new cell-mirror). There are many deficiencies of the previous system ${ }^{6}$ which make its application virtually impossible. For example, with the multi-layer mirror the laser is located on the Earth's surface and its beam moves (from the laser to the ship and back to the laser) through the Earth's atmosphere a lot of times. The computation shows that the beam's energy will quickly be lost due to absorption and scattering by the Earth's (or Mars) atmosphere when it travels a long distance though it. In our system the beam moves through the atmosphere only once time and reflects between the Moon mirror and the space ship of all other times. This is insured by the innovation of the light lock.

Another deficiency of the laser-based sail system is that when the space ship is close to Earth, the sail will reflect the beam back to the laser. If the efficiency of the propulsion system were sufficient, the laser might be damaged or destroyed. This problem is absent in the author system because it uses a "light lock", which closes the return path of laser beam.

The suggested laser ring (a set of small lasers located in a circle), beam transfer and self-focused mirror and Fresnel's lens decrease the beam divergence and increase the beam transfer distance. It is 
possible to install the cell-mirror on the Moon or on Mars and transfer a laser beam to them and then to make a space ship decelerates.

The other system ${ }^{6}$ requires a nuclear electric power station (of several Giga Watts Power) to be built and to deliver it, and a super powerful laser on Mars.

I do not mean to criticize other small mistakes in the work $[6, \mathrm{p} .1]$ as, for example, the computation of multiple reflection acceleration (thrust) is not correct. The beam energy after every reflection will be decreased and the ship acceleration also will be decreased. For a large number of reflections this decrease is quite large (see the equations in this Part 2).

The idea of a multiple reflection engine and cell and superconductivity mirrors was probably offered first by author in 1983 [7, p. 1]. But as I know, this work [6, p. 1] (2001) was the first research on this topic which is important.

General discussion. The offered multi-reflex light launcher, space and air focused energy transfer system is very simple (needing only special mirrors, lenses and prisms), and it has a high efficiency. One can directly transfer the light beam into space acceleration and mechanical energy. A distant propulsion system can obtain its energy from the Earth. However, we need very powerful lasers. Sooner or later the industry will create these powerful lasers (and cell mirrors) and the ideas presented here will become possible. The research on these problems should be started now.

Multi-reflex engines ${ }^{7}$ may be used in aviation as the energy can be transferred from the power stations on the ground to the aircraft using laser beams. The aircraft would no longer carry fuel and the engine would be lighter in weight so its load capability would double. The industry produces a one Megawatt $(1000 \mathrm{~kW})$ laser now. This is the right size for mid-weight aircraft (10-12 tons).

The linear light engine does not have a limit to its speed and may be used to launch space equipment and space ships in non-rockets method described in [1-16]. This method is certain also to have many military applications.

\section{Part 3 \\ Plasma Beam Space Propulsion for Interstellar Flight*}

\section{Summary}

In this Part author offers a revolutionary method - non-rocket transfer of energy and thrust into Space with distance of millions kilometers. The author has developed theory and made the computations. The method is more efficient than transmission of energy by high-frequency waves. The method may be used for space launch and for acceleration the spaceship and probes for very high speeds, up to relativistic speed by current technology. Research also contains prospective projects which illustrate the possibilities of the suggested method.

Keywords: space transfer of energy, space transfer of thrust, transferor of matter, transfer of impulse (momentum), interplanetary flight, interstellar flight.

\section{Introduction}

Transportation of energy, matter, or impulse is very important for long period space trips especially for lengthy distance voyages. The spaceship crew or astronauts on planets can need additional energy or ship thrust. Most people think that is impossible to transfer energy a long distance in outer space except electromagnetic waves. Unfortunately, electromagnetic waves have a big divergence and cannot be used at a long distance (millions of kilometers) transfer.

However, the space vacuum is very good medium for offered method and special transfer of energy and momentum.

\footnotetext{
* Presented as paper AIAA-2006-7492 to Conference "Space-2006", 19-21 September, 2006, San-Jose, CA, USA.
} 
Brief history. About 40 years ago scientists received plasma flow having speed up $1000 \mathrm{~km} / \mathrm{s}$, power $10 \mathrm{~kW}$, mass consumption $0.1 \mathrm{~g} / \mathrm{s}$, electric current up million amperes.

However, the application of plasma beam into space needs a series of inventions, innovations and researches. In particular, they include methods of decreasing the plasma divergence, discharging, dispersion of velocity, collection the plasma beam in space at long distance from source, conversion of the beam energy into electricity and other types of energy, conversion of plasma impulse (momentum) in space apparatus thrust, conversion of plasma into matter, control, etc.

The author started this research more than forty years ago [1]. The solutions of the main noted problems and innovations are suggested by author in early (1982-1983) patent applications [2] - [12] (see also further development in [13]-[34]) and given article. In particularly, the main innovations are:

1. Using neutral plasma (not charged beam);

2. Using ultra-cool plasmaor particle beam in conventional temperature;

3. Control electrostatic collector which separates and collects the ions at spaceship;

4. Control electrostatic generator which convert the ion kinetic energy into electricity;

5. Control electrostatic ramjet propulsion;

6. Special control electrostatic mirror-reflector;

7. Recombination photon engine;

8. Recombination thermo-reactor.

9. Research is made for conventional and relativistic particle speeds.

About 20 years ago the scientists received the ultra-cold plasma having the ion temperature lower than $1 \times 10^{-3} \mathrm{~K}$. Velocity dispersion was $10^{-4} \div 10^{-6}$, beam divergence for conventional temperature was $10^{-3}$ radian.

If plasma accelerator is designed special for getting the ultra-cold plasma, its temperature may be appreciably decreased. There is no big problem in getting of cold ions from solid electrodes or cold electrons from solid points where molecular speed is small.

\section{Description of Innovation}

Innovative installation for transfer energy and impulse includes (Figure 1): the ultra-cold plasma injector, electrostatic collector, electrostatic electro-generator-thruster-reflector, and space apparatus. The plasma injector creates and accelerates the ultra-cold low density plasma.

The Installation works the following way: the injector-accelerator forms and injects the cold neutral plasma beam with high speed in spaceship direction. When the beam reaches the ship, the electrostatic collector of spaceship collects and separates the beam ions from large area and passes them through the engine-electric generator or reflects them by electrostatic mirror. If we want to receive the thrust in the near beam direction $\left( \pm 90^{\circ}\right)$ and electric energy, the engine works as thruster (accelerator of spaceship and breaker of beam) in beam direction and electric generator. If we want to get thrust in opposed beam direction, the space engine must accelerate the beam ions and spend energy. If we want to have maximum thrust in beam direction, the engine works as full electrostatic mirror and produces double thrust in the beam direction (full reflection of beam back to injector). The engine does not spend energy for full reflection.

The thrust is controlled by the electric voltage between engine nets [19], the thrust direction is controlled by the engine nets angle to beam direction. Note, the trust can slow the ship (decrease the tangential ship speed) and far ship (located out of Earth orbit) can return to the Earth by Sun gravity. Note also, the Earth atmosphere absorbs and scatters the plasma beam and the beam injector must be located on Earth space mast or tower (up $40 \div 60 \mathrm{~km}$, see [20;21]) or the Moon. Only high energy beam 
can break through atmosphere with small divergence. The advantage: the injector has a reflector and when the ship locates not far from the injector the beam will be reflected a lot of times and thrust increases in thousand times at start (Figure 2) (see same situation in [22]).

The proposed engine may be also used as AB-ramjet engine [19], utilizing the Solar wind or interstellar particles.

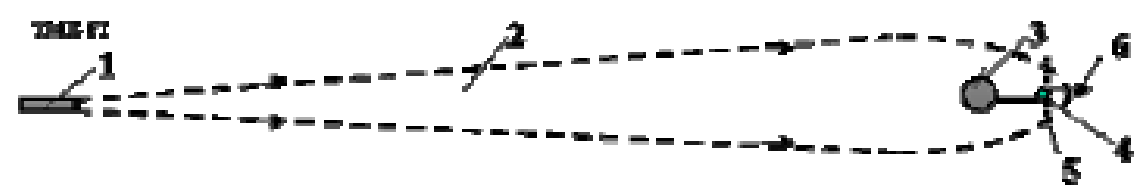

Figure 1. Long distance space transfer of electric energy, matter, and momentum (thrust). Notation are: 1 injector-accelerator of neutral ultra-cold plasma (ions and electrons), 2 - plasma beam, 3 - space ship or planetary team, 4 - electrostatic ions collector (or magnetic collector), 5 - braking electric nets (electrostatic electrogenerator-thruster-reflector), 6 - thrust.

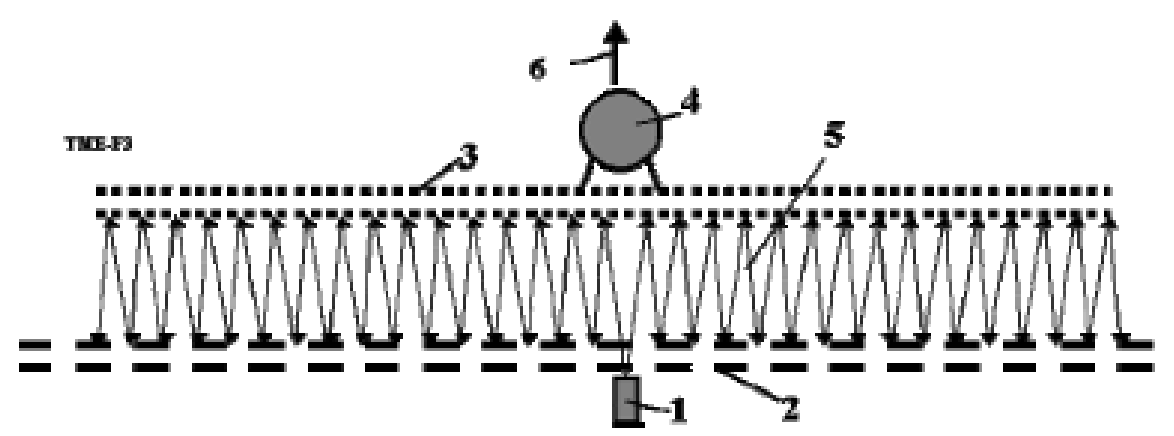

Figure 2. Multi-reflection start of the spaceship having proposed engine. Notation are: 1 - injector-accelerator of cold ions or plasma, 2, 3 - electrostatic reflectors, 4 - space ship, 5 - plasma beam, 6 - the thrust.

The electrostatic collector and electrostatic generator-thruster-reflector proposed and described in [19]. The main parts are presented below.

A Primary Ramjet propulsion engine is shown in [27, Figure 1 or [34, Fig. 1, Ch.2]. Such an engine can work in charged environment. For example, the surrounding region of space medium contains positive charge particles (protons, ions). The engine has two plates 1,2, and a source of electric voltage and energy (storage) 3. The plates are made from a thin dielectric film covered by a conducting layer. The plates may be a net. The source can create an electric voltage $U$ and electric field (electric intensity $E)$ between the plates. One also can collect the electric energy from plate as an accumulator.

The engine works in the following way. Apparatus are moving (in left direction) with velocity $V$ (or particles 4 are moving in right direction). If voltage $U$ is applied to the plates, it is well-known that main electric field is only between plates. If the particles are charged positive (protons, positive ions) and the first and second plate are charged positive and negative, respectively, then the particles are accelerated between the plates and achieve the additional velocity $v>0$. The total velocity will be $V+v$ behind the engine (Figure 3a). This means that the apparatus will have thrust $T>0$ and spend electric energy $W<0$ (bias, displacement current). If the voltage $U=0$, then $v=0, T=0$, and $W=0$ (Figure $3 \mathrm{~b}$ ).

If the first and second plates are charged negative and positive, respectively, the voltage changes sign.

Assume the velocity $v$ is satisfying $-V<v<0$. Thus the particles will be braked and the engine (apparatus) will have drag and will also be braked. The engine transfers braked vehicle energy into electric (bias, displacement) current. That energy can be collected and used. Note that velocity $v$ cannot equal $-V$. If $v$ were equal to $-V$, that would mean that the apparatus collected positive particles, accumulated a big positive charge and then repelled the positive charged particles. 


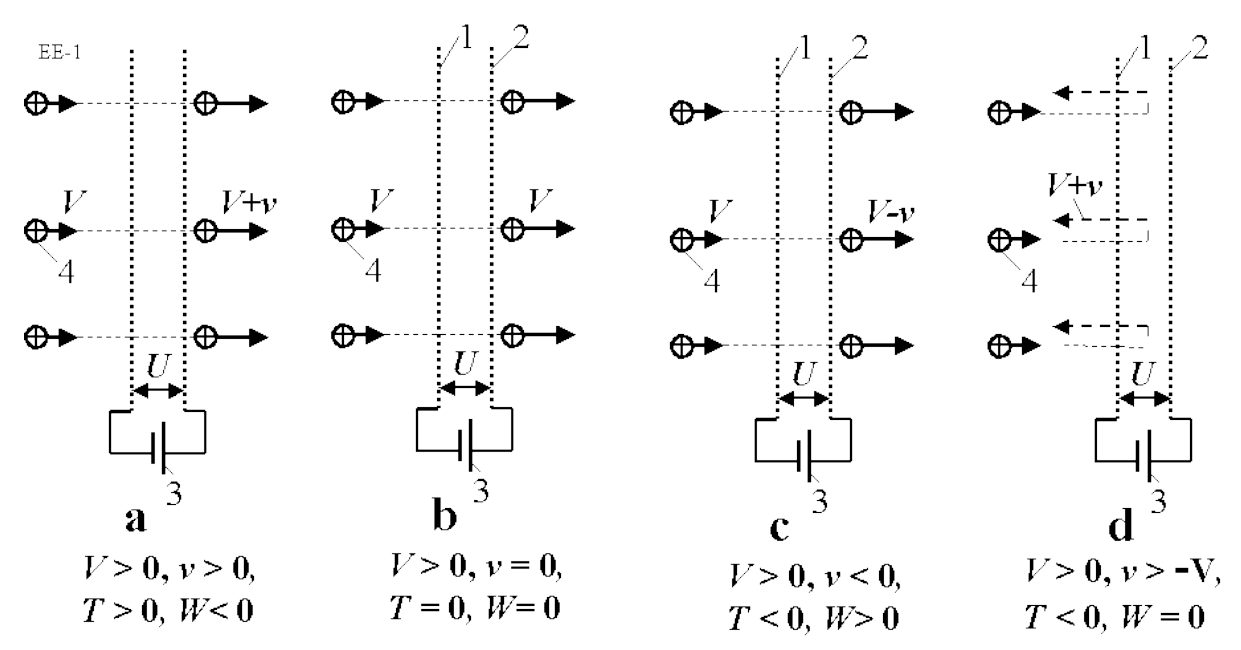

Figure 3. Explanation of primary Space Ramjet propulsion (engine) and electric generator (in braking),a) Work in regime thrust; b) Idle; c) Work in regime brake. d) Work in regime strong brake (full reflection). Notation: 1 , 2 - plate (film, thin net) of engine; 3 - source of electric energy (voltage U); 4 - charged particles (protons, ions); $\mathrm{V}$ - speed of apparatus or particles before engine (solar wind); $\mathrm{v}$ - additional speed of particles into engine plates; $\mathrm{T}$ - thrust of engine; $\mathrm{W}$ - energy (if $\mathrm{W}<0$ we spend energy).

If the voltage is high enough, the brake is the highest (Figure3d). Maximum braking is achieved when $v=-2 V(T<0, W=0)$. Note, the $v$ cannot be more then $-2 V$, because it is full reflected speed. $A B$-Ramjet engine. The suggested Ramjet is different from the primary ramjet. The suggested ramjet has specific electrostatic collector 5 (Figure 4a,c,d,e,f,g). Other authors have outlined the idea of space matter collection, but they did not describe and not research the principal design of collector. Really, for charging of collector we must move away from apparatus the charges. The charged collector attracts the same amount of the charged particles (charged protons, ions, electrons) from space medium. They discharged collector, work will be idle. That cannot be useful.

The electrostatic collector cannot adsorb matter (as offered some inventors) because it can adsorb ONLY opposed charges particles, which will be discharged the initial charge of collector. Physic law of conservation of charges does not allow us to change charges of particles.

The suggested collector and ramjet engine have a special design (thin film, net, special form of charge collector, particle accelerator). The collector/engine passes the charged particles ACROSS (through) the installation and changes their energy (speed), deflecting and focusing them. That is why we refer to this engine as the $A B$-Ramjet engine. It can create thrust or drag, extract energy from the kinetic energy of particles or convert the apparatus' kinetic energy into electric energy, and deflect and focus the particle beam. The collector creates a local environment in space because it deletes (repeals) the same charged particles (electrons) from apparatus and allows the Ramjet to work when the apparatus speed is close to zero. The author developed the theory of the electrostatic collector and published it in [26]. The conventional electric engine cannot work in usual plasma without the main part of the AB-engine - the special pervious electrostatic collector.

The plates of the suggested engine are different from the primary engine. They have concentric partitions which create additional radial electric fields (electric intensity) (Figure 4b). They straighten, deflect and focus the particle beams and improve the efficiency coefficient of the engine.

The central charge can have a different form (core) and design (Figure 4c,d,e,f,g,h). It may be:

(1) a sphere (Figure 4c) having a thin cover of plastic film and a very thin (some nanometers) conducting layer (aluminum), with the concentric spheres inserted one into the other (34, Figure $4 d)$, 
(2) a net formed from thin wires (Figure 4e);

(3) a cylinder (without butt-end)(Figure 4f); or

(4) a plate (Figure $4 \mathrm{~g}$ ).

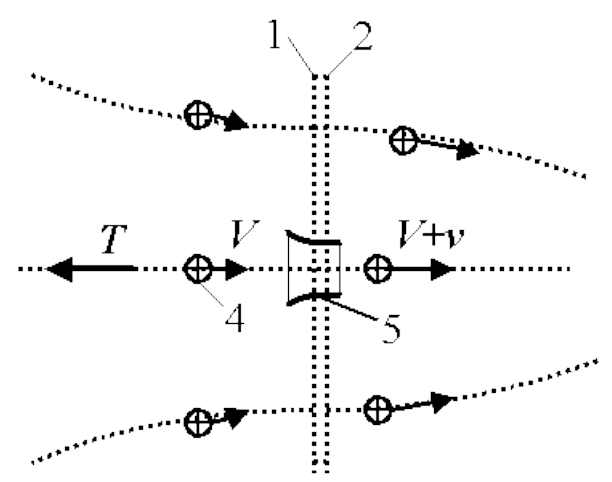

a
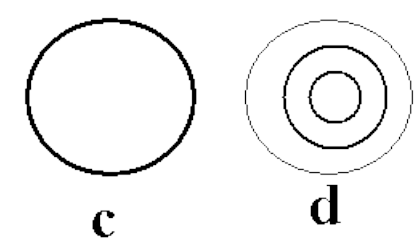
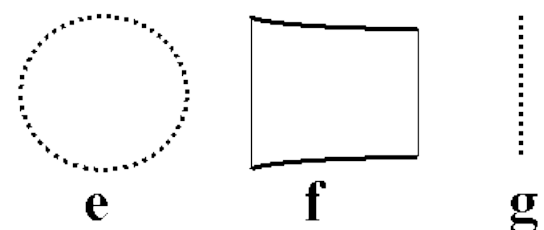

Figure 4. Space AB-Ramjet engine with electrostatic collector (core). a) Side view; b) Front view; c) Spherical electrostatic collector (ball); d) Concentric collector; e) cellular (net) collector; f) cylindrical collector without cover butt-ends; g) plate collector (film or net).

The design is chosen to produce minimum energy loss (maximum particle transparency - see section "Theory"). The safety (from discharging, emission of electrons) electric intensity in a vacuum is $10^{8} \mathrm{~V} / \mathrm{m}$ for an outer conducting layer and negative charge. The electric intensity is more for an inside conducting layer and thousands of times more for positive charge.

The engine plates are attracted one to the other (see theoretical section). They can have various designs (Figure 5a-5d). In the rotating film or net design (Figure 5a), the centrifugal force prevents contact between the plates. In the inflatable design (Figure 3b, Ch. 2), the low pressure gas prevents plate contact. A third design has (inflatable) rods supporting the film or net (Figure 3c, Ch. 2). The fourth design is an inflatable toroid which supports the distance between plates or nets (Figure 5d).

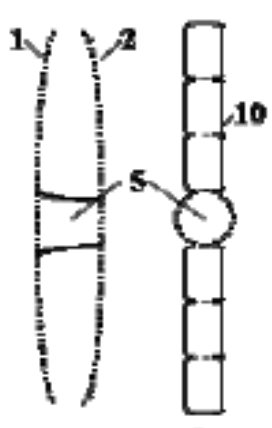

5

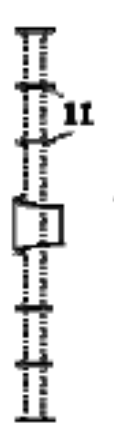

b
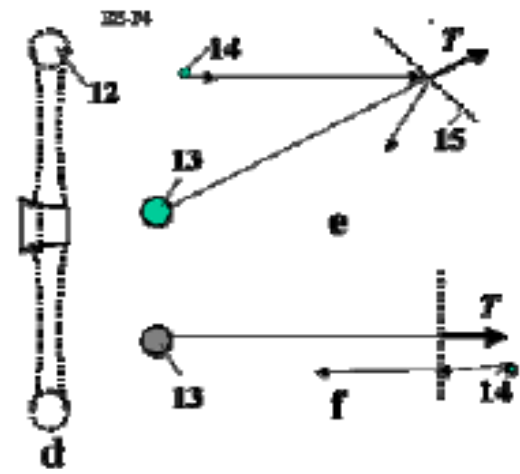

Figure 5. Possible design of the main part of ramjet engine. a) Rotating engine; b) Inflatable engine (filled by gas); c) Rod engine; d) Toroidal shell engine, e) AB-Ramjet engine in brake regime, f) AB-Ramjet engine in thrust regime. Notation: 10 - film shells (fibers) for support thin film and creating a radial electric field; 11 - Rods for a support the film or net; 12 - inflatable toroid for support engine plates; 13 - space apparatus; 14 - particles; 15 - AB-Ramjet 
Note, the AB-ramjet engine can work using the neutral plasma. The ions will be accelerated or braked, the electrons will be conversely braked or accelerated. But the mass of the electrons is less then the mass of ions in thousands times and AB-engine will produce same thrust or drag.

Plasma accelerator. The simplest linear plasma accelerator (principle scheme of linear particle accelerator) for plasma beam is presented in Figure 6. The design is a long tube (up $10 \mathrm{~m}$ ) which creates a strong electric field along the tube axis $(100 \mathrm{MV} / \mathrm{m}$ and more). The accelerator consists of the tube with electrical isolated cylindrical electrodes, ion source, and voltage multiplier. The accelerator increases speed of ions, but in end of tube into ion beam the electrons are injected. This plasma accelerator can accelerate charged particles up $1000 \mathrm{MeV}$. Electrostatic lens and special conditions allow the creation of a focusing and self-focusing beam which can transfer the charge and energy long distances into space. The engine can be charged from a satellite, a spaceship, the Moon, or a top atmosphere station (space tower $[19 ; 28]$ ). The beam may also be used as a particle beam weapon.

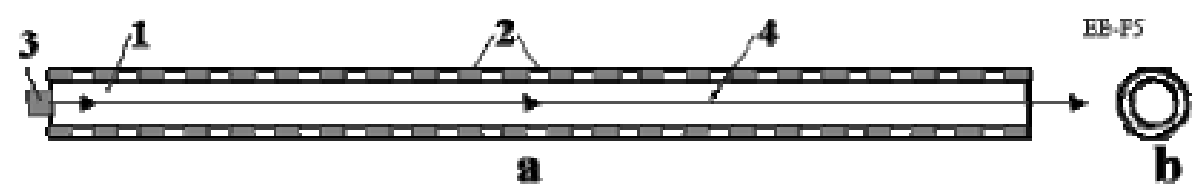

Figure 6.Electric gun for charging AB-Ramjet engine and transfer charges (energy) in long distance.a) Side view, b) Front view. Notations: 1 - gun tube, 2 - opposed charged electrodes, 3 - source of charged particles (ions, electrons), 4 - particles beam.

Approximately ten years ago, the conventional linear pipe accelerated protons up to $40 \mathrm{MeV}$ with a beam divergence of $10^{-3}$ radian. However, acceleration of the multi-charged heavy ions may result in significantly more energy.

At present, the energy gradients as steep as $200 \mathrm{GeV} / \mathrm{m}$ have been achieved over millimeter-scale distances using laser pulses. Gradients approaching $1 \mathrm{GeV} / \mathrm{m}$ are being produced on the multicentimeter-scale with electron-beam systems, in contrast to a limit of about $0.1 \mathrm{GeV} / \mathrm{m}$ for radiofrequency acceleration alone. Existing electron accelerators such as SLAC $<$ http://en.wikipedia.org/wiki/SLAC> could use electron-beam afterburners to increase the intensity of their particle beams. Electron systems in general can provide tightly collimated, reliable beams while laser systems may offer more power and compactness.

The cool plasma beam carries three types of energy: kinetic energy of particles, ionization, and dissociation energy of ions and molecules. That carry also particle mass and momentum. The AB-Ramjet engine (described over) can utilize only kinetic energy of plasma particles and momentum. The particles are braked and produce an electric current and thrust or reflected and produce only thrust in the beam direction. If we want to collect a plasma matter and to utilize also the ionization energy of plasma (or space environment) ions and dissociation energy of plasma molecules we must use the modified $\mathrm{AB}$ Ramjet engine described below (Figure 7).

The modified AB-engine has magnetic collector (option), three nets (two last nets may be films), and issue voltage (that also may be an electric load). The voltage, $U$, must be enough for full braking of charged particles. The first two nets brake the electrons and precipitate (collect) the electrons on the film 2 (Figure 7). The last couple of film (2, 3 in Figure 3 ) brakes and collects the ions. The first couple of nets accelerate the ions that is way the voltage between them must be double. The collected ions and electrons have the ionized and dissociation energy. This energy is significantly (up 20 - 150 times) more powerful then chemical energy of rocket fuel (see Table 1) but significantly less then kinetic energy of particles (ions) equal $U$ (in eV) ( $U$ may be millions volts). But that may be used by ship. The ionization energy conventionally pick out in photons (light, radiation) which easy are converted in a heat (in closed vessel), the dissociation energy conventionally pick out in heat. 


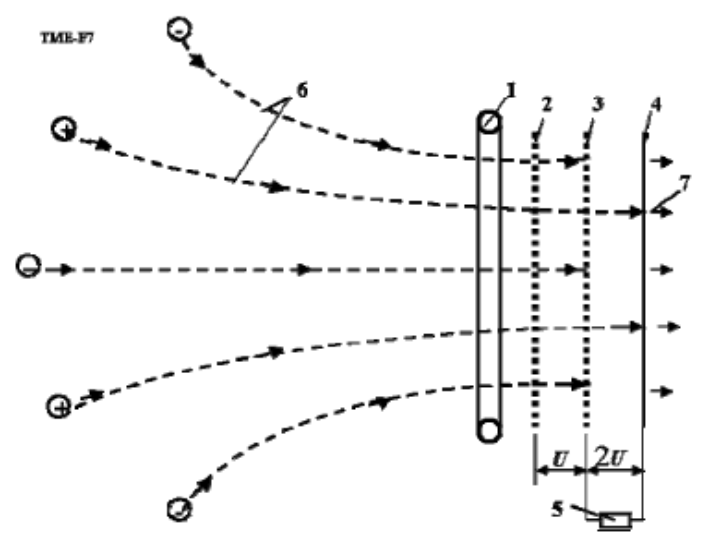

Figure 7. AB-engine which collected matter of plasma beam, kinetic energy of particles, energy ionization and dissociation. Notations: 1 - magnetic collector; 2 - 4 - plates (films, nets) of engine; 5 - electric load; 6 - particles of plasma; 7 - radiation. $U$ - voltage between plates (nets).

The light energy may be used in the photon engine as thrust (Figure 8a) or in a new power laser (Figure 8b). The heat energy may be utilized conventional way (Figure 8c). The offered new power laser (Figure $8 \mathrm{~b}$ ) works the following way. The ultra-cool rare plasma with short period of life time located into cylinder. If we press it (decrease density of plasma) the electrons and ions will connect and produce photons of very closed energy (laser beam). If we compress very quickly by explosion the power of beam will be high. The power is only limited amount of plasma energy.

After recombination ions and electrons we receive the conventional matter. This matter may be used as nuclear fuel (in thermonuclear reactor), medicine, food, drink, oxidizer for breathing, etc.

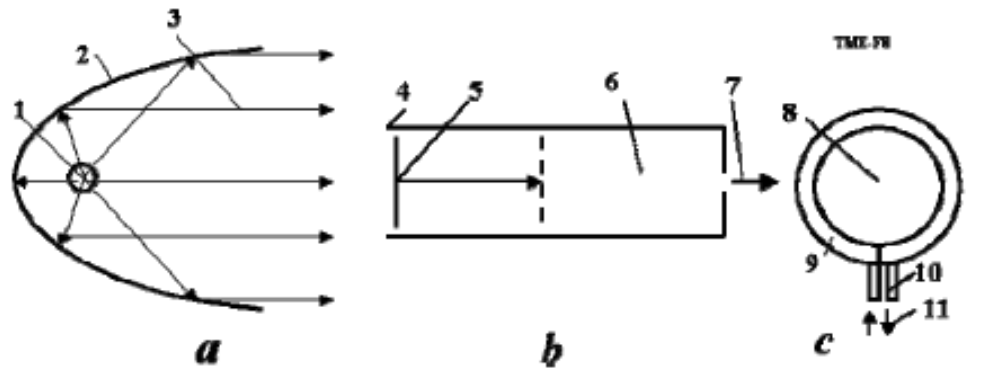

Figure 8.Conversion of ionization energy into radiation and heat.a- photon engine; $b$ - power laser (light beamer); c - heater. Notations: 1 - recombination reactor; 2 - mirror; 3 - radiation (light) beam; 5 - piston; 6 - volume filled by cold rare plasma; 7 - beam; 8 - plasma; 9 - heat exchanger; 10 - enter and exit of hear carrier; 11 - heat carrier.

\section{Transfer Theory of the High Speed Neutral Ultra-Cold Plasma and Particles}

Below are the main equations and computations of neutral ultra-cold plasma beam having velocity up to relativistic speed. These equations received from conventional mechanics and relativistic theory.

Note a ratio $\beta$

$$
\beta=\frac{V}{c}, \quad \beta_{S}=\frac{V_{S}}{c}
$$

where $V$ is plasma beam speed, $\mathrm{m} / \mathrm{s} ; c=3 \times 10^{8}$ is light speed, $\mathrm{m} / \mathrm{s} ; V_{s}$ is projection of a ship speed in beam direction.

1. Relative relativistic time ${ }^{\bar{t}}$, for observer moving together with beam is 


$$
\bar{t}^{\prime}=\frac{t^{\prime}}{t}=\sqrt{1-\beta^{2}},
$$

where $t^{\prime}$ is time for observer moving together with beam (system coordinate connected with beam)[s], $t$ is time for Earth's observer [s]. Computation of Eq. (2) is presented in Figure 9. The beam time decreases for relativistic speed. That means the beam divergence is also decreased and beam energy may be passed for long distance.

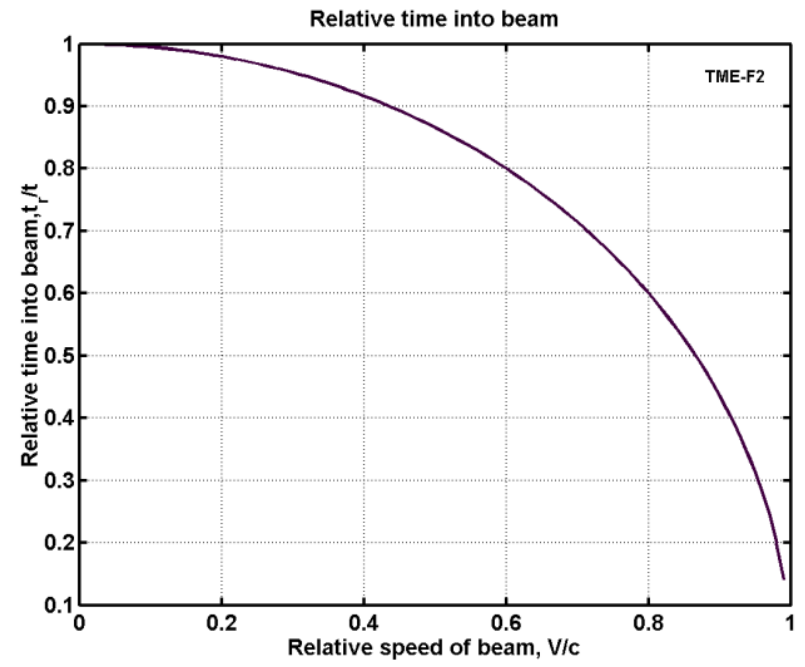

Figure 9. Beam relative time versus beam relative speed for high relativistic beam speed.

2. The power spent for acceleration plasma beam in Earth for efficiency $=1$ (kinetic power of particle beam) is

$$
P_{B}=\frac{M_{0} c^{2}}{2} \frac{\beta^{2}}{\sqrt{1-\beta^{2}}}, \quad \text { or for } \beta<<1 \quad P_{B}=\frac{M_{0} V^{2}}{2} \quad \text { [W] }
$$

where $M_{0}$ is mass flow of beam, $\mathrm{kg} / \mathrm{s}$ in Earth system of coordinate.

The computations of Eq. (3) for the intervals $(0 \div 0.1) c$ and $(0 \div 0.95) c$ are presented in Figures 6, 6a.

The relativistic speed needs very high power in any method because the relativistic beam requires this energy.

3. The power $P_{i}$ of dissociation and single ionization of one nucleon is

$$
P_{i}=1.6 \times 10^{-19} \frac{M_{0}}{m_{p} n} e_{i} \quad[\mathrm{~J} / \mathrm{s}] \quad \text { or } \quad P_{i}=\frac{M_{0}}{m_{p} n} e_{i} \quad[\mathrm{eV} / \mathrm{s}]
$$

where $m_{\mathrm{p}}=1.67 \times 10^{-27} \mathrm{~kg}$ is mass of proton, $n$ is number of nucleon in nucleus, $e_{\mathrm{i}}$ is energy of dissociation, ionization, or molecular breakup respectively. The energy of the first ionization (ion lost one electron) approximately equals from 2 to $14 \mathrm{eV}$. Magnitudes of this energy for some molecules and ions are in Table No.1.

Table 1. Energy ionization, dissociation, and molecular breakup of some molecules and ions in $e V$.

\begin{tabular}{|l|l|l|l|l|}
\hline $\begin{array}{l}\text { Molecular } \\
\text { breakup }\end{array}$ & $\mathrm{H}_{2} \mathrm{O} \rightarrow \mathrm{H}_{2}+\mathrm{O}$ & $2 \mathrm{eV}$ & $\mathrm{CO}_{2} \rightarrow \mathrm{C}+\mathrm{O}_{2}$ & $0.093 \mathrm{eV}$ \\
\hline Dissociation & $\mathrm{H}_{2} \rightarrow \mathrm{H}+\mathrm{H}$ & $4.48 \mathrm{eV}$ & $\mathrm{O}_{2} \rightarrow \mathrm{O}+\mathrm{O}$ & $5.1 \mathrm{eV}$ \\
\hline Ionization & $\mathrm{H} \rightarrow \mathrm{H}^{+}$ & $13.6 \mathrm{eV}$ & $\mathrm{H}_{2} \rightarrow \mathrm{H}_{2}^{+}$ & $2.65 \mathrm{eV}$ \\
\hline Ionization & $\mathrm{O}_{2} \rightarrow \mathrm{O}_{2}^{+}$ & $6.7 \mathrm{eV}$ & & \\
\hline
\end{tabular}




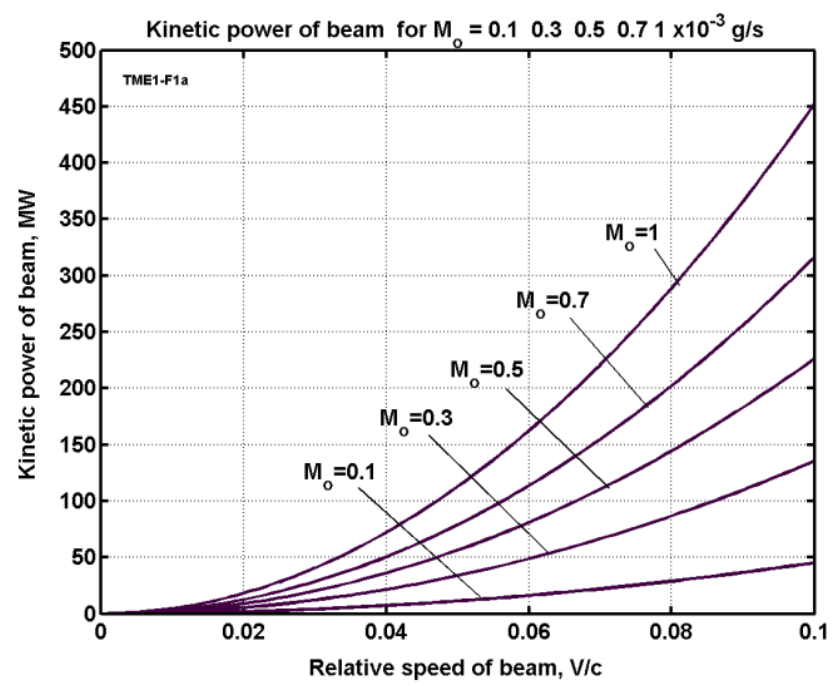

Figure 10.Power for the beam acceleration via beam flow mass and relative beam speed for interval. $(0 \div 0.1) c$.

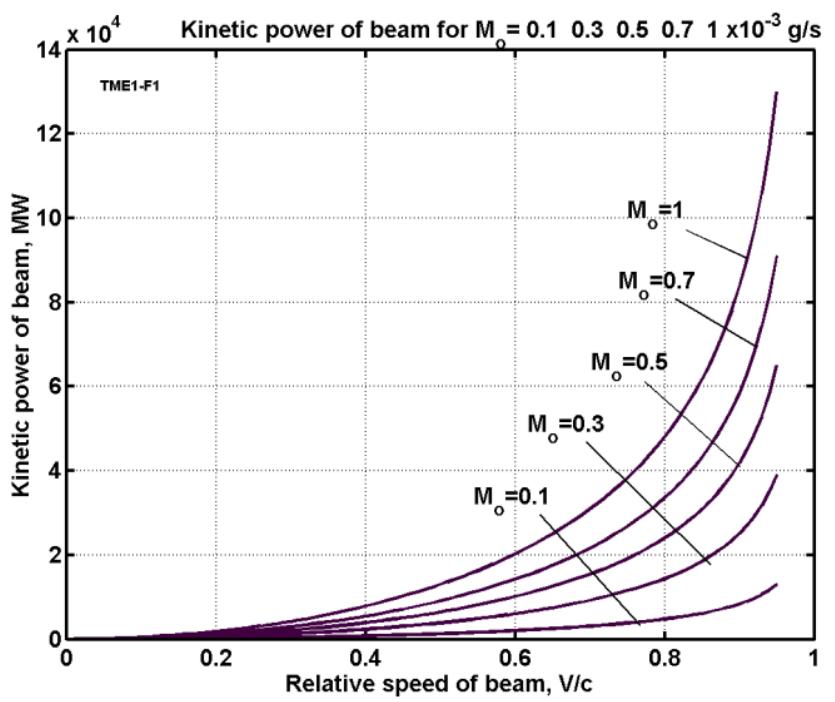

Figure 10a. Power for the beam acceleration via beam flow mass and relative beam speed for interval $(0 \div 0.95) c$.

If speed is relativistic, this energy is small in comparison with kinetic energy of beam. For interplanetary speed $\left(V_{\mathrm{S}}=8-15 \mathrm{~km} / \mathrm{s}\right)$ the energy of ionization reaches $15-50 \%$ from kinetic energy of beam. That decreases the coefficient of efficiency launch installation. If we used the heavy ions or a charged matter, the ionization energy decreases but voltage increases. For interplanetary vehicles it is not important because required voltage for low speed are small $(U \approx 5 \div 20 \mathrm{~V})$.

Figure 11 shows the required energy for different case 


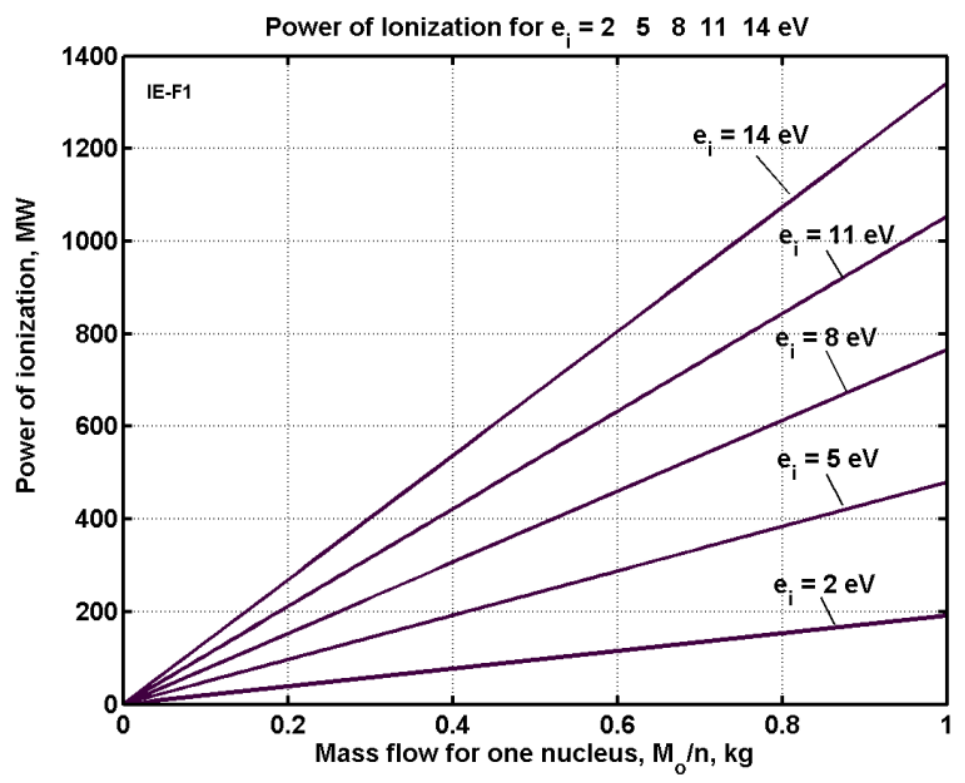

Figure 11. Power of ionization versus mass flow and ionization potencial (Eq. (4)).

4. The maximal thrust (drag) from the full reflected one charged plasma beam, for Earth's observer and relativistic speed and non-relativistic speed may be estimated by following equations:

$T_{\max }=2 M\left(V \mp V_{S}\right) \approx \frac{2 M_{0} c\left(\beta \mp \beta_{S}\right)}{\sqrt{1-\beta^{2}}}, \quad$ or for $\beta_{S}<<1$ the thrust is $T_{n a x}=\frac{2 M_{0} c \beta}{\sqrt{1-\beta^{2}}}$,

for $\beta<<1, \quad \beta_{S}<<1, \quad$ the thrust is $T_{\max }=2 M_{0}\left(V-V_{S}\right)$

Here $M$ is calculated mass of a moving relativistic particle flow, $\mathrm{kg} / \mathrm{s} ; M_{0}$ is mass of the particle flow measured by Earth's observer, $\mathrm{kg} / \mathrm{s}$.

Note: If the space ship move along the beam in same direction, the thrust is decreased (sign is "-"); if that moves in opposed direction, the drag is increased (sing is "+"). This drag (thrust) is not requested the ship propulsion energy.

Result of computation for intervals $(0 \div 0.1) c,(0 \div 0.95) c, V_{\mathrm{S}}=0$ are presented in Figure 12, $12 \mathrm{a}$.

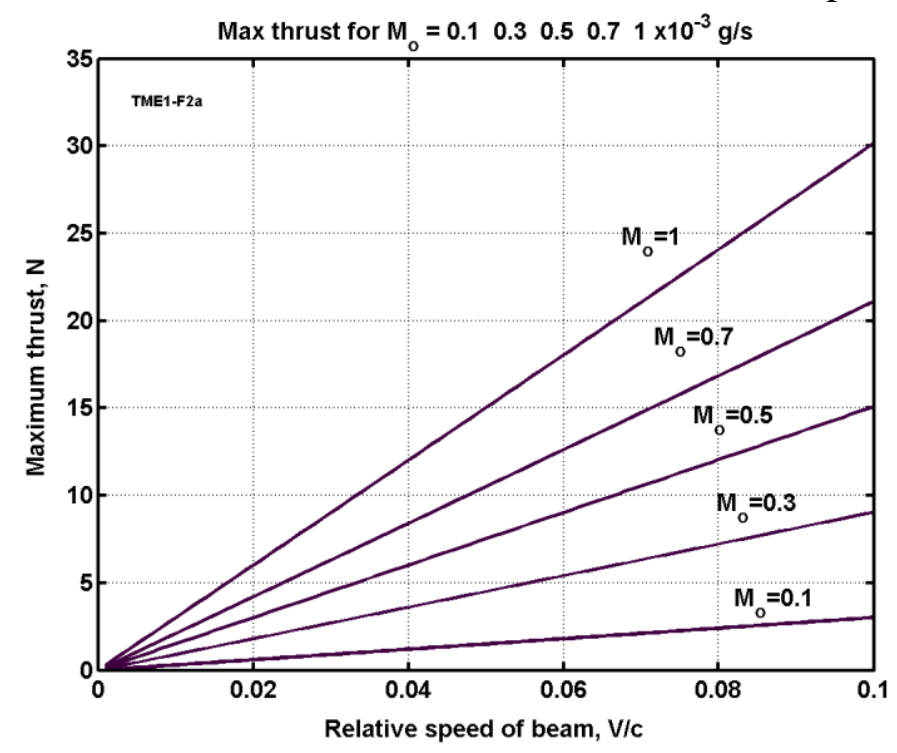

Figure 12. Maximum thrust (drag) is produced by beam in space ship for $V_{S}=0$ and the interval $(0 \div 0.1)$ c. 


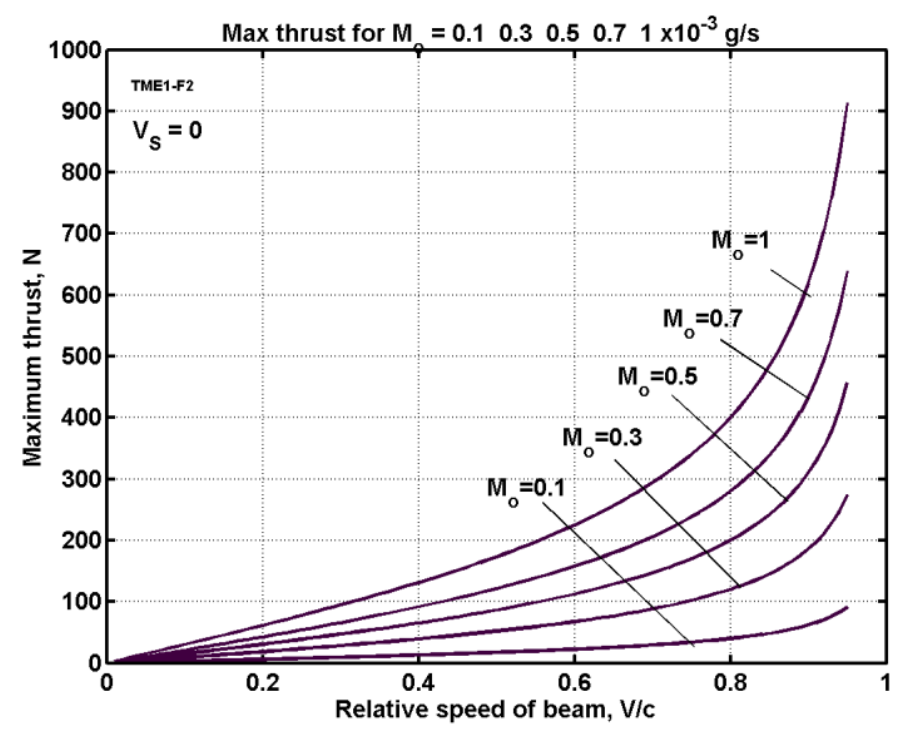

Figure 12a. Maximum thrust (drag) is produced by beam in space ship for $V_{S}=0$ and interval $(0 \div 0.95)$ c.

5. The divergence of beam is a very important magnitude. If divergence is small, we can pass our energy in long distance $S$ :

$$
D=\frac{u t^{\prime}}{V t}=\frac{u}{c} \frac{\sqrt{1-\beta^{2}}}{\beta} S, \quad \bar{D}=\frac{D}{S}, \quad S=c \beta t
$$

where $u$ is maximal radial speed, $\mathrm{m} / \mathrm{s} ; D$ is maximal radial distance (radius of plasma beam), $\mathrm{m} ; \bar{D}$ is relative divergence (angle of divergence, $\theta=2 \bar{D}$ radians); $t$ is time of beam moving, s.

The computation of Eq. (6) is shown in Figure 9. We need in small $u$ (ultra-cold plasma) for decreasing of divergence as small as possible $(u=0.01-1 \mathrm{~m} / \mathrm{s})$. In this case we can transfer energy in the large distance and accelerate a ship for relativistic speed. The plasma is mixture of ions and electrons. If it is low-density, it can exist a long time. The cold plasma can be emitted from solid electrodes.

Note: Equations (2),(6) shows when $V \rightarrow c$, then $t^{\prime} \rightarrow 0$ and deviation $D \rightarrow 0$. That means the deviation can be small as we want but we need a big power for it.

The corresponding temperature is

$$
T_{c}=\frac{m u^{2}}{i k},
$$

Where $m$ is mass of molecule (ion) $[\mathrm{kg}] ; m=m_{p} n$, here $m_{\mathrm{p}}=1.67 \times 10^{-27}$ is mass of proton, $n$ is number of nucleons into nucleus; $i=3$ for single ion (for example $O^{+}$), $i=5$ for double molecule (for example $\left.O_{2}^{+}\right), i=6$ for multi-molecular ions, $k=1.39 \times 10^{-23}$ is Boltzmann constant.

For $u=0.1 \div 1 \mathrm{~m} / \mathrm{s}$ the temperature is about $10^{-30} \mathrm{~K}$, the relative divergence is $10^{-9}$. 


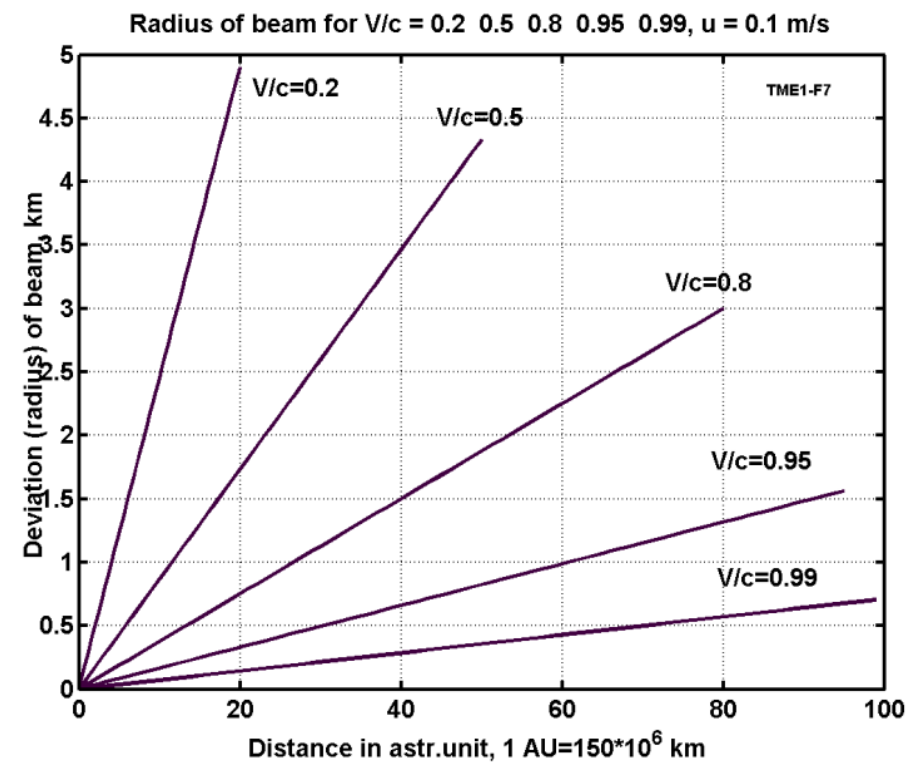

Figure 13. Radius of beam divergence via distance and ratio V/c.

6. Accelerate voltage is

$$
U=\frac{m V^{2}}{2 q}=\left(\frac{m_{p}}{q}\right) \frac{n c^{2}}{2} \frac{\beta^{2}}{\sqrt{1-\beta^{2}}},
$$

where $q=1.6 \times 10^{-19} \mathrm{C}$ is electron (ion) charge. The computations are presented in Figure 14, 14a. The need voltage may be reduced in $Z$ times if the ion has $Z$ charges (delete $Z$ electrons from ion).

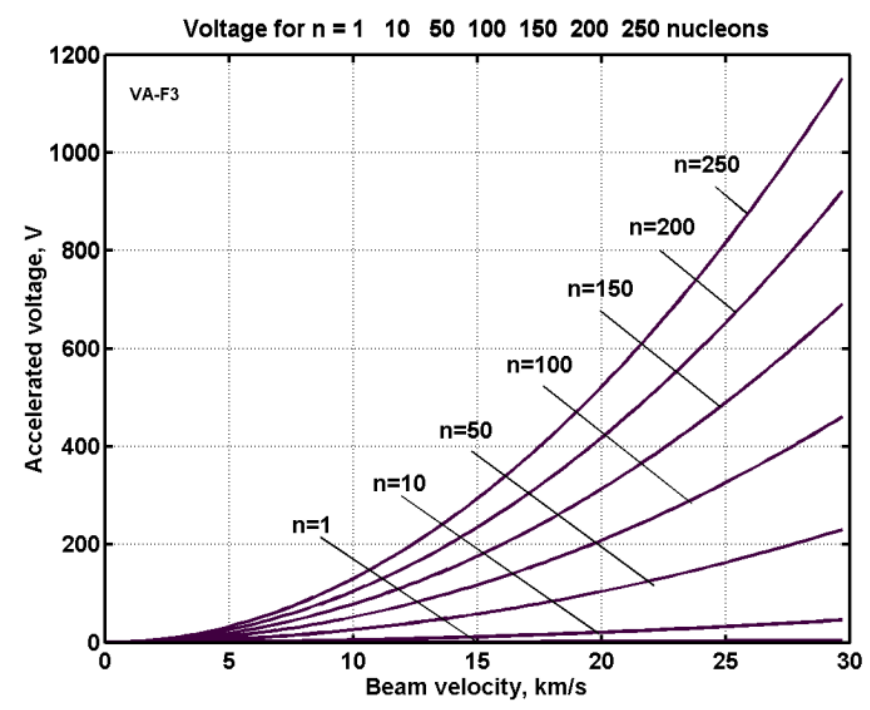

Figure 14. Accelerated voltage versus the conventional beam speed and number of nucleons. 


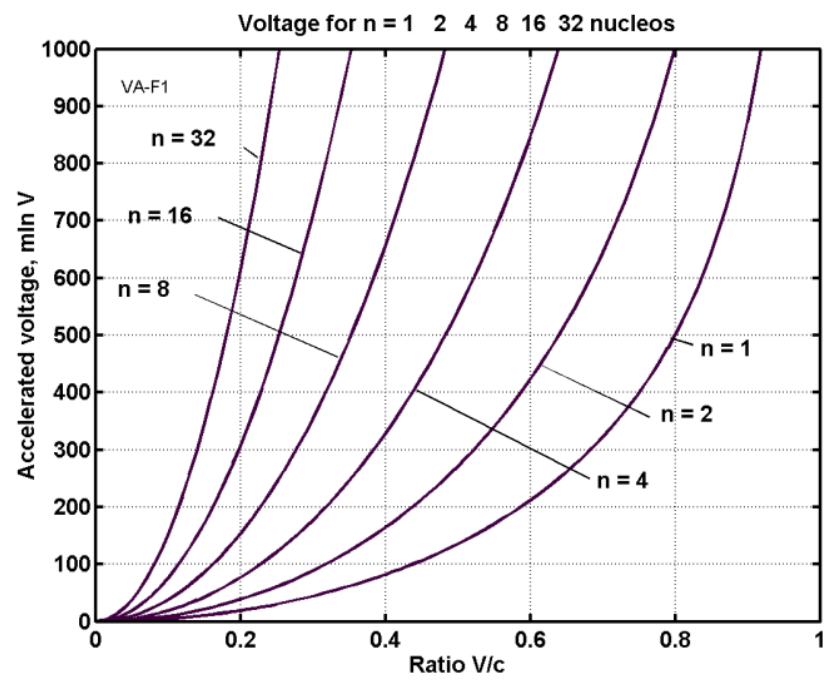

Figure 14a. Accelerated voltage versus a relativistic speed ratio V/c and number of nucleons.

7. The speed $V_{s}$ and distance of space shipS can be computed by conventional method (Earth's observer):

$$
V_{S}=a t, \quad S=\frac{a t^{2}}{2}, \quad S=\frac{V_{S}^{2}}{2 a}, \quad a=\frac{T}{M_{S}},
$$

$a$ is ship acceleration, $\mathrm{m} / \mathrm{s}^{2} . M_{\mathrm{s}}$ is ship mass, $\mathrm{kg}, V_{\mathrm{S}}$ is ship speed measured by Earth's observer, $\mathrm{m} / \mathrm{s}$.

8. Relative beam speed for a ship observer is

$$
\beta_{B S}=\frac{\beta \pm \beta_{S}}{1+\beta \beta_{S}}
$$

where $\beta, \beta_{\mathrm{S}}$ is relative speed of beam and space ship respectively measured by Earth's observer. The sign " -" is used for same direction of speeds.

9. Loss energy of the beam in the Earth atmosphere may be estimated by the following way:

$$
\tau=\frac{100 H_{0} \rho_{0} \bar{\rho}(h) \bar{p}(h)}{R_{t}(U)}, \quad R_{t}=\frac{m}{m_{p}} R_{t}\left(\frac{m_{p}}{m} U\right)
$$

where $H_{0}=P_{a} / \rho=10^{4} / 1.225=8163 \mathrm{~m}$ is thickness (height) of Earth atmosphere having constant density $\rho=1.225 \mathrm{~kg} / \mathrm{m}^{3}, P_{a}=10^{4} \mathrm{~kg} / \mathrm{m}^{2}$ is the atmospheric pressure; $\bar{\rho}(h)$ is relative atmosphere density; $\bar{p}(h)$ is relative atmosphere pressure; $R_{\mathrm{t}}$ is particle track in atmosphere $[\mathrm{cm}] ; m$ is mass of particle, $\mathrm{kg} ; h$ is altitude, $\mathrm{m} ; U$ is beam energy, $\mathrm{MeV} ; \rho_{\mathrm{o}}=0,001225 \mathrm{~g} / \mathrm{cm}^{3}$ is atmosphere density; 100 is transfer coefficient meter into cm. Magnitudes $R_{\mathrm{t}}, \bar{\rho}(h), \bar{p}(h)$ for proton are given below in Tables 2, 3.

Table 2. Value $R_{t}\left[\mathrm{~g} / \mathrm{cm}^{2}\right]$ versus energy of proton in MeV, [32], p. 953

\begin{tabular}{|l|l|l|l|l|l|l|l|l|l|}
\hline$U \mathrm{MeV}$ & 0.1 & 1 & 10 & 50 & 100 & 200 & 300 & 400 & 500 \\
\hline$R_{\mathrm{t}} \mathrm{g} / \mathrm{cm}^{2}$ & $1 \times 10^{-4}$ & $1.09 \times 10^{-2}$ & $0,99 \times 10^{-1}$ & 2.56 & 8.835 & 29.64 & 58.08 & 93.73 & 133.3 \\
\hline $\mathrm{U}$ & 600 & 700 & 800 & 1000 & 2000 & 3000 & 5000 & 7000 & 10,000 \\
\hline $\mathrm{R}_{\mathrm{t}}$ & 176 & 222 & 270 & 370 & 910 & 1363 & 2543 & 3583 & 5081 \\
\hline
\end{tabular}

Table 3. Standard Earth atmosphere, [33], p. 261

\begin{tabular}{|l|l|l|l|l|l|l|l|}
\hline$h \mathrm{~km}$ & 0 & 5 & 10 & 20 & 40 & 60 & 100 \\
\hline $\bar{\rho}(h)$ & 1 & 0.661 & 0.338 & 0.072 & $3.27 \times 10^{-3}$ & $2.71 \times 10^{-4}$ & $4.41 \times 10^{-7}$ \\
\hline $\bar{p}(h)$ & 1 & 0.533 & 0.261 & 0.054 & $2.92 \times 10^{-3}$ & $8.35 \times 10^{-4}$ & $3.20 \times 10^{-7}$ \\
\hline
\end{tabular}


Results of computation Eq. (10) are presented in Figure 15, 15a, $15 \mathrm{~b}$.

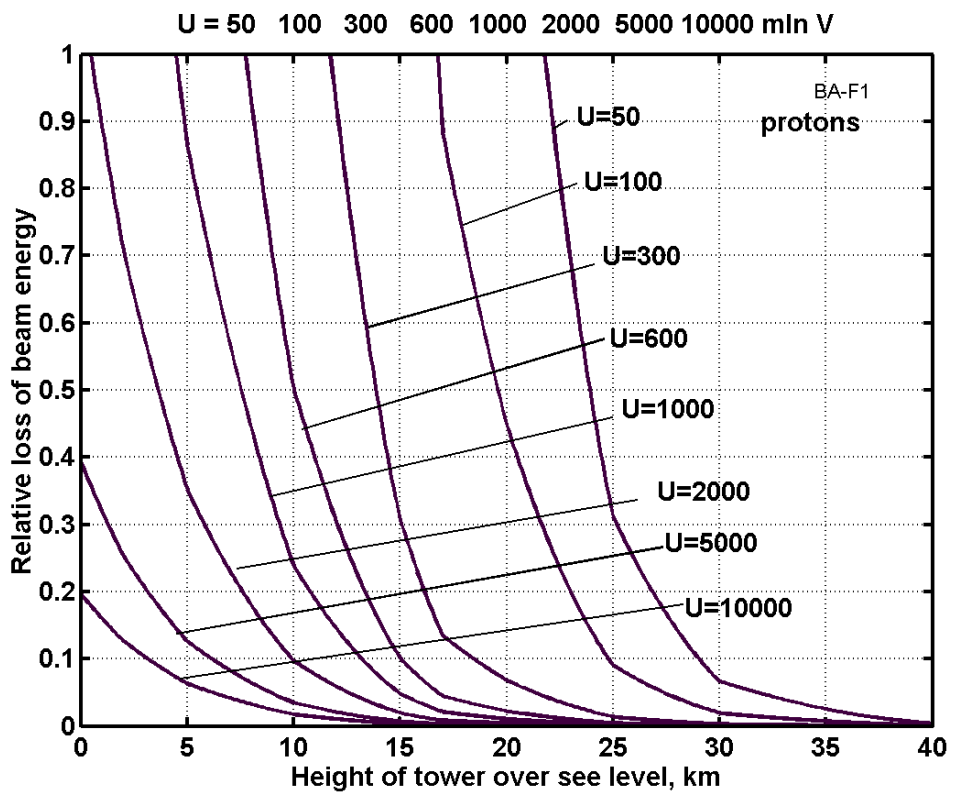

Figure 15. Relative energy loss of the proton particle beam via a tower altitude in Earth atmosphere. Accelerate voltage $U$ are in millions volts.

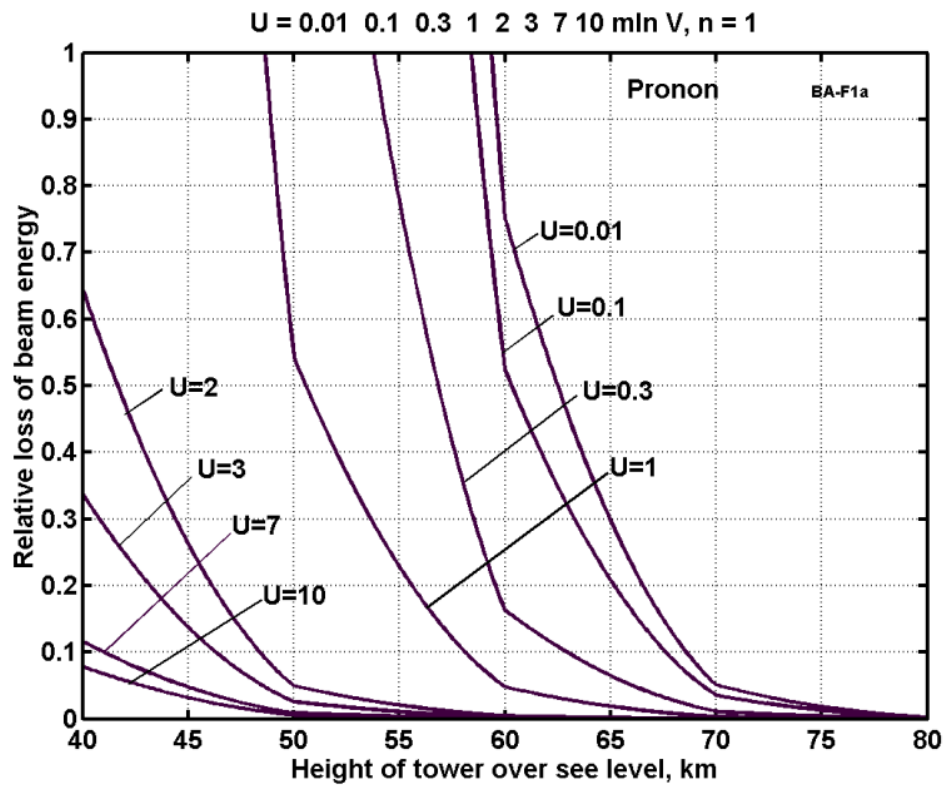

Figure 15a. Relative energy loss of the proton particle beam via a tower altitude in Earth atmosphere. Accelerate voltage $U$ are in millions volts. Angles in curve are result of the linearization data of Table 2, 3 . 


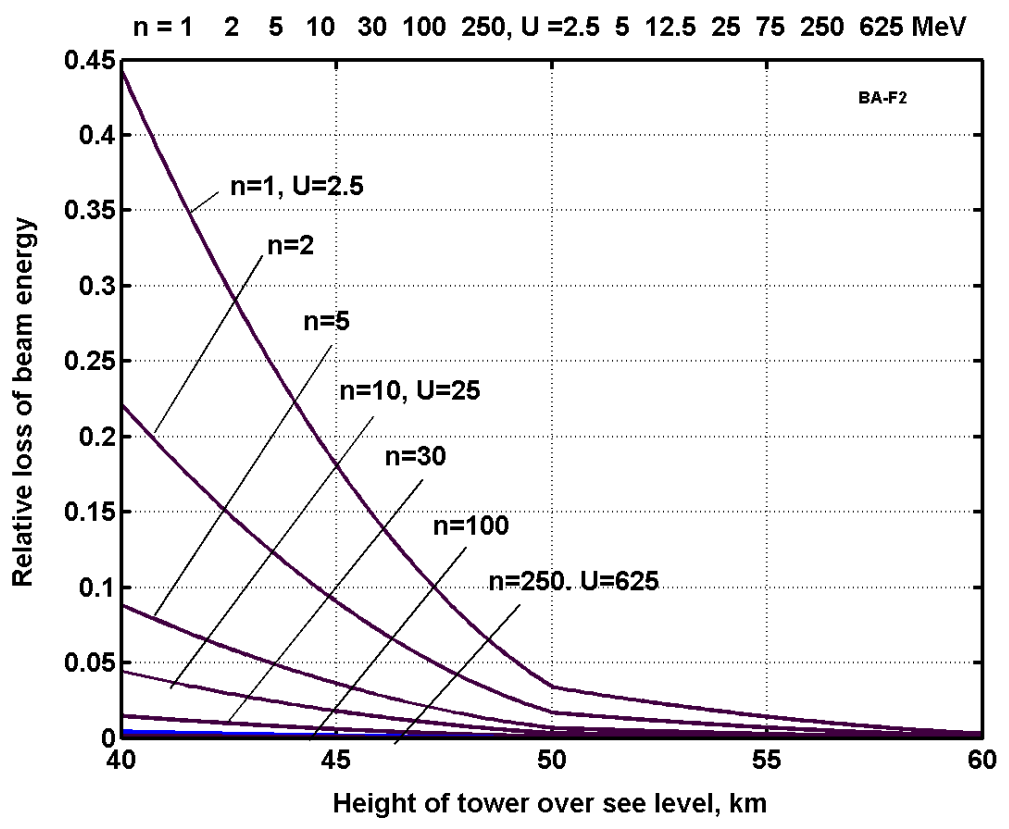

Figure 15b. Relative energy loss of the particle beam via the tower altitude in Earth atmosphere and number $n$ of nucleons in nucleus. Accelerate voltage $U$ in millions volts.

Evidently, only high energy particle beam break up the Earth atmosphere. There is no problem if the particle beam starts from a space tower [20], [25] of $40 \div 80 \mathrm{~km}$ altitude or from the Moon.

Last formula in (10) allows recalculation by the particle track for any atom. For example, we want tocalculate the particle track for oxidizer particle having $m=16 m_{\mathrm{p}}$ and energy $8,000 \mathrm{MeV}$. We take the $R_{\mathrm{t}}$ from Table 2 for $U=8,000 / 16=500 \mathrm{MeV}$ and multiple by 16 . Result $R_{\mathrm{t}}=133 \times 16=2128$. The particle $\operatorname{track} T_{\mathrm{r}}=R_{\mathrm{t}} / \rho_{\mathrm{o}}=2128 / 0.001225=1737142 \mathrm{~cm}=17.4 \mathrm{~km}$ in the air having density $1.225 \mathrm{~kg} / \mathrm{m}^{3}$. That is enough to break the Earth's atmosphere of the constant density $8.163 \mathrm{~km}$, but the loss of energy will be $\tau=8.163 / 17.4=0.47(47 \%)$. The divergence may also be increased by atmosphere. Loss and divergence may be improved is the beam station is located on a mountain or special tower having the height about $40 \div 60 \mathrm{~km}$.

10. Multi-reflex launch and landing (Figure2). In a starting or braking period the thrust (braking) can be increasingif we use the multi-reflect method developed in [26]. Multi-reflect in launching does not increased the installation power (thrust is increased by increasing of efficiency), multi-reflex in braking converts the apparatus kinetic energy into the electric energy which can be utilized by apparatus or operated station. The theory of multi-reflection is described below (see also [26]).

11. Change in beam power. The beam power will be reduced if one (or both) reflector is moved, because the beam speed changes. The total relative loss, $q$, of the beam energy in one double cycle (when the beam is moved to the reflector and back) is

$$
q=(1-2 \gamma)(1-2 \xi)(1 \pm 2 v) \varsigma, q>0
$$

where $v$ is the loss (useful work) through relative mirror (lens) movement, $v=V_{S} / V, V_{S}$ is the relative speed of the electrostatic mirrors (space apparatus) $[\mathrm{m} / \mathrm{s}], V=$ is the speed of the beam (in system of coordinates connected with an power operating station). We take the "+" when the distance is reduces (braking) and take "-“"when the distance is increased (as in launching, a useful work for beam), $\gamma$ is coefficient reflectivity of electrostatic mirror (the loss of beam energy through the electrostatic reflector); $\xi$ is the loss (attenuation) in the medium (air) (see point 8). If no atmosphere, $\xi=0 ; \varsigma$ is the loss through beam divergence ( $\varsigma=1$ if $D<D_{\mathrm{r}}$, where $D_{\mathrm{r}}$ is diameter of the electrostatic mirror). For a wire net 
electrostatic reflector $\gamma \approx 2 d_{w} / l$ where $d_{w}$ is diameter of wire, $l$ is size of mesh. For example, for the net having a mesh $0.1 \times 0.1 \mathrm{~m}$, the $l=0.1 \mathrm{~m}$ and a wire $d_{w}=0.0001 \mathrm{~m}$, the $\gamma=0.002$.

Multi-reflex light pressure. The beam pressure, $T$, of two opposed high reflectors after a series ofreflections, $N$, to one another is

$$
T\left(V_{S}\right)=T_{0}+\frac{2 P_{B}}{V} \sum_{j=1}^{N} q^{j}\left(V_{S}\right), \quad N\left(V_{S}\right)=\sqrt{\frac{k D_{r} V}{u S}} . \quad P_{B}=\frac{M_{0} V^{2}}{2} . \quad T_{0}=2 M_{0}\left(V-V_{S}\right) \geq 0
$$

where $S$ is distance between electrostatic reflectors of the station and ship [m], $k=1 \div 1.5$ is correction coefficient for the case when $D>D_{\mathrm{r}}$. For primary estimation $k=1$.

If $V_{\mathrm{S}}$ is small and $V$ is high, the multi-reflex $T$ may be large. For example, if $V_{\mathrm{S}}=10 \mathrm{~m} / \mathrm{s}, V=30 \mathrm{~km} / \mathrm{s}, S$ is small, the number of reflection may reach $n \approx 30000 / 10 / 2=1500$ times more then regular thrust. That is well for ship trip starting and braking.

12. Limitation of reflection number. If the reflector is moved away, the maximum number of reflections, $N$, is limited by $q>0, V_{\mathrm{S}}<0.5 \mathrm{~V}$ (see Eq. (11)). At ship launch or braking the maximum thrust is limited by a safety acceleration or deceleration.

Coefficient of efficiency. The propulsion efficiency coefficient, $\eta$, (without loss for ionization) may be computed using the equation

$$
\eta=T V_{S} / P_{B}
$$

For full reflection Eq. (13) has the form:

$$
\eta=\frac{4\left(V-V_{S}\right) V_{S}}{V^{2}}, \quad \eta_{\max }=1 \text { for } V=2 V_{S}
$$

Computation of launch and landing trajectories computed by the usual method of integration

$$
\begin{gathered}
a_{i}=T / M_{S}, \quad t_{i+1}=t_{i}+\Delta t, \quad V_{S, i+1}=V_{S, i}+a_{i} \Delta t, \quad S_{i+1}=S_{i}+V_{S, i} \Delta t \\
\text { Project }
\end{gathered}
$$

(Interstellar probe having speed $30.000 \mathrm{~km} / \mathrm{s}$, weight $0.1 \mathrm{~kg}$ )

Let us assume we want to estimate an interstellar probe which can reach the nearest solar systems. As known they are located about 4 - 60 light years from our Sun. That means the apparatus having speed $\square_{\mathrm{S}}=0.1 \mathrm{c}\left(V_{\mathrm{S}}=30,000 \mathrm{~km} / \mathrm{s}\right)$ can reach them in $40-60$ years. Reminder, "Voyager-1" was flown for $30+$ year, sending information up to present time. But it has speed only $20 \mathrm{~km} / \mathrm{s}$ and was reached only the boundary of Solar system (about 2 billion $\mathrm{km}$ ).

Assume, the weight of interstellar probe is $0.1 \mathrm{~kg}$. If distance of acceleration is $S=1.5 \times 10^{11} \mathrm{~m}(1$ $\mathrm{AU})$ the acceleration and acceleration time must be

$$
a=\frac{V_{S}^{2}}{2 S}=\frac{9 \cdot 10^{14}}{2 \cdot 1.5 \cdot 10^{11}}=3 \cdot 10^{3} \mathrm{~m} / \mathrm{s}^{2}, \quad t=\frac{V_{S}}{a}=\frac{3 \cdot 10^{7}}{3 \cdot 10^{3}}=10^{4} \mathrm{sec}=167 \mathrm{~min}=2.78 \text { hours } .
$$

The thrust, requested acceleration energy and power are

$T=a M_{S}=3 \cdot 10^{3} \cdot 0.1=300 \mathrm{~N}, \quad W=\frac{M_{S} V_{S}^{2}}{2}=\frac{0.1 \cdot 9 \cdot 10^{14}}{2}=4.5 \cdot 10^{13} \mathrm{~J}, \quad P=\frac{W}{t}=\frac{4.5 \cdot 10^{13}}{10^{4}}=4.5 \mathrm{GW}$,

The mass of the beam flow, and energy spent by beam station are (Eq. (3),(5))

$$
\begin{aligned}
& M_{0}=\frac{T \sqrt{1-\beta^{2}}}{2 c\left(\beta-\beta_{S}\right)}=\frac{300 \sqrt{1-0.01}}{2 \cdot 3 \cdot 10^{8}(0.1-0.05)} \approx 10^{-5} \mathrm{~kg} / \mathrm{s}, \\
& P_{B}=\frac{M_{0} c^{2}}{2} \frac{\beta^{2}}{\sqrt{1=\beta^{2}}}=\frac{10^{-5} \cdot 9 \cdot 10^{16} 0.01}{2 \sqrt{1-0.01}}=4.5 \mathrm{GW}
\end{aligned}
$$

Here $\beta_{\mathrm{S}}=0 \div 0.1$. We take the average value $\beta_{\mathrm{S}}=0.05$. Notice that $P_{\mathrm{B}}=P$, that means our installation transfer the station energy to ship with efficiency $=1$. Unfortunately, this energy is very high. Tens of 
electric power stations must accelerate this probe in 23 days. We cannot decrease this amount by any methods because that is a minimum energy required by space probe.

Divergence $D$ for $u=0.01 \mathrm{~m} / \mathrm{s}$, voltage $U(n=1)$, jet speed $\beta=0.1$ and plasma temperature $T_{\mathrm{p}}$ are

$$
\begin{aligned}
& D=\frac{u}{c} \frac{\sqrt{1-\beta^{2}}}{\beta} S \approx \frac{0.01}{3 \cdot 10^{8}} \frac{1.5 \cdot 10^{11}}{0.1}=500 \mathrm{~m}, \quad T_{p}=\frac{m u^{2}}{i k}=\frac{1,67 \cdot 10^{-27} 10^{-4}}{3 \cdot 1.38 \cdot 10^{-23}}=0.4 \cdot 10^{-8} \quad{ }^{0} \mathrm{~K}, \\
& U=\left(\frac{m_{p}}{q}\right) \frac{n c^{2}}{2} \frac{\beta^{2}}{\sqrt{1-\beta^{2}}} \approx\left(\frac{1.67 \cdot 10^{-27}}{1.6 \cdot 10^{-19}}\right) \frac{1 \cdot 9 \cdot 10^{16}}{2} \frac{0.01}{1}=4.7 \cdot 10^{6} \mathrm{~V} .
\end{aligned}
$$

For jet speed $\beta=0.9$ divergence $D=25 \mathrm{~m}$, for jet speed $\beta=0.99$ divergence $D=7 \mathrm{~m}$, The power of dissociations $\left(H_{2} \rightarrow H+H, 2.2 \mathrm{eV}\right)$ and ionization $\left(H \rightarrow H^{+}, 13,6 \mathrm{eV}\right)$ are equal

$$
E_{i}=1.6 \cdot 10^{-19}\left(e_{d}+2 e_{i}\right) \frac{M_{0}}{m_{p} n}=1.6 \cdot 10^{-19}(2.2+2 \cdot 13.6) \frac{10^{-5}}{1.67 \cdot 10^{-27} \cdot 2}=14 \mathrm{~kW} .
$$

In given case (comparison with $P_{\mathrm{B}}$ above) this value is small and we can negligee it. But into planetary flight $\left(V \approx 8-30 \mathrm{~km} / \mathrm{s}\right.$ and large $\left.M_{0}\right)$ this energy is essential.

\section{Discussion of Part 3}

In [33] G.A. Landis writes about using particle beams for interstellar flight. The beam is braked by a magnetic sail. Unfortunately, as with most other works in this field, his work also contains only common speculations. No theory, no mathematical models, no computations. More then ten years authors investigate the magnetic sail, but not its theory, no formulas which allows correct calculation or to estimate the magnetic sail drug. Moreover, the most MagSail works contain a common mistake (see 34 Chapter 4 "Electrostatic MagSail"). Landis offered the beam temperature $45^{\circ} \mathrm{K}$. The theory in this article is shown that this temperature gives the beam divergence which does not allows the interstellar flights. Absolutely unsubstantiated statement that magnetic sail reflects beam in thousands kilometers diameter. The estimations show for high speed particles especially relativistic particles the affective diameter equals some meters and magnetic field must be powerful. In additional the magnetic sail is impossible at present time: electric ring needs in cryogenic temperature and spaceship must have power cryogenic equipment because the Sun will warm the ring for any heat insulation; for starting the ring needs a power electric station; a special equipment is necessary for displacing the ring of $100 \mathrm{~km}$ diameter into space; if the ring temperature exceeds a critical cryogenic temperature in any ring place, the ring explodes. The ring weight is big ( 22 tons for diameter $100 \mathrm{~km}$ ), the produced magnetic field is very weak $\left(10^{-6}\right.$ Tesla). The magnetic sail does not have active control. That means the ship will move in one (non-control) direction and a ship mission will useless. These obvious defects make it impossible the application of the magnetic sail with little or no progress in solution these problems since 1988.

The suggested method does not require a magnetic sail. That used the electrostatic sail [26] and AB-Ramjet engine offered by author early. This sail is light (100 - $300 \mathrm{~kg})$, cheap, and has tens kilometers (hundreds $\mathrm{km}$ for low beam density) of the effective radius. For example, for solar wind the magnetic effective radius decreases proportional $1 / R^{2}$ (where $\mathrm{R}$ is distance of the sail from the Sun), electrostatic effective radius decreases approximately $1 / R$ (see [26]). That is very important advantage.

\section{Conclusion Part 3}

The offered idea and method use the AB-Ramjet engine suggested by author in 1982 [3; 4; 6; 8; $9 ; 12 ; 14-16 ; 18]$ and detail developed in [28]. The installation contains an electrostatic particle collector suggested in 1982 and detail developed in [26; 30]. The propulsion-reflected system is light net from thin wire, which can have a large area (tens $\mathrm{km}$ ) and allows to control thrust and thrust direction without turning of net (Figure1). This new method uses the ultra-cold full neutral relativistic plasma and having small divergence. The method may be used for acceleration space apparatus (up relativistic speed) for launch and landing Space apparatus to small planets (asteroids, satellites) without atmosphere. For Earth 
offered method will be efficiency if we built the tower (mast) about $40 \div 80 \mathrm{~km}$ height [19; 24]. At present time that is the most realistic method for relativistic probe.

\section{References}

\section{References to Part 1}

1. R.L. Garwin, "Solar Sailing - A practical Method of Propulsion within the Solar System," Jet Propulsion, Vol. 28, March 1958, pp. 188-190.

2. R.L. Forward, "Pluto - The Gateway to the Stars, "Missiles and Rockets, Vol. 10, April 1962, pp. 70-75.

3. A. Kantrowitz, "Propulsion to Orbit by Ground-Based Lasers", Astronautics and Aeronautics, Vol.10, pp. 74-76, May, 1972.

4. Collection "Beamed Energy Propulsion". First International Symposium on Beamed Energy Propulsion. Melville, New York, 2003. American Institute of Physics.

5. A.A. Bolonkin, "Light Pressure Engine". Patent (Author Certificate) \# 1183421, 1985, USSR, (priority on 5 January, 1983).

6. R.A. Metzger and G. Landis, "Multi-Bounce Laser-Based Sails", Proceedings of the shape Technology and Application, Forum-2001, Albuquerque, New Mexico, 2001, AIP Conference Proceedings, Vol. 552, pe. 397 [File: STAIF $2001 \mathrm{~B}$ ].

7. A.A. Bolonkin, "Light Multreflex Engine", JBIS, Vol. 57, No. 9/10, pp. 353-359 (2004).

8. P.W. Milonni, J.H. Eberly, Lasers, John Wiley \& Sons, NY.

9. R.G. Driggers, (ed.), Encyclopedia of Optical Engineering., New York, Marcel Dekker, Inc.

10. A.A. Bolonkin, "Multi-Reflex Propulsion Systems for Space and Air Vehicles and Energy Transfer for Long Distance", JBIS, Vol. 57, No. 11/12. 2004, pp. 379-390, 2004.

\section{References to Part 2}

1.Bolonkin A.A., Method for Interstellar Flight. Ch.13 pp.195-214 in book "Innovations and New Technologies (v2).Lulu, 2013. 465 pgs.10.5 Mb, ISBN: 978-1-312-62280-7. https://archive.org/details/Book5InnovationsAndNewTechnologiesv2102014/,

https://www.academia.edu/11058394/Innovations_and_New_Technologies_v.2_USA_Lulu_2013

2. Bolonkin A.A., Beam Space Propulsion, arXiv:physics/0701057. Presented as paper AIAA2006-7492 to conference "Space-2006", 19-21 September, 2006, San Jose, California, USA. See also in book Bolonkin A., New Concepts, Ideas and Innovations in Aerospace, Technology and Human Sciences, NOVA, ISBN-13:978-1-60021-787-6, 2006.Ch.3, pp.67-93.

3. Bolonkin A.A., Non-Rocket Space Launch and Fligth, Elsevier, 2005. 488 pgs. ISBN-13: 978-0-08044-731-5, ISBN-10: 0-080-44731-7 .Chapters.12, A3, pp.223-270,371-382. https://archive.org/details/Non-rocketSpaceLaunchAndFlightv.3 , (v.3) , http://vixra.org/abs/1407.0174,

4. Bolokin A.A., Multi-reflex Propulsion System for Space and Air Vehicles and Energy Transfer for

Long Distance, Journal British interplanetary Society, Vol.57, No 11/12, 2004, pp.379-390.

5. Bolokin A.A., Multi-reflex Engine, Journal British interplanetary Society, Vol.57, No 9/10, 2004, pp.353-359

6. Bolonkin A.A., AB-Space Propulsion . 2008,arXiv:0803.0089

7. Bolonkin A. A., "Light Pressure Engine", Patent (Author Certificate) \# 1183421, 1985, USSR, (priority on January 5, 1983).

8. Bolonkin A. A., Cumulative Thermonuclear AB-Reactor. Energy,Sustainability and Society, Springer, v.6, issue 1, $2016 . \quad$ http://viXra.org/abs/1507.0053 https://archive.org/details/ArticleCumulativeReactorFinalAfterCathAndOlga7716,

9. Bolonkin A. A., Inexpensive Mini Thermonuclear Reactor. International Journal of Advanced Engineering Applications, Vol.1, Iss.6, pp.62-77 (2012). http://viXra.org/abs/1305.0046, http://archive.org/details/InexpensiveMiniThermonuclearReactor .

10.Bolonkin A. A., Converting of Matter to Nuclear Energy by AB-Generator American Journal of Engineering and Applied Science, Vol. 2, \#4, 2009, pp.683-693. Presented as paper AIAA-2009-5342 in 
45 Joint Propulsion Conferences, 2-5 August, 2009, Denver, CO. http://viXra.org/abs/1309.0200, https://www.academia.edu/14515398/Converting_of_Matter_to_Nuclear_Energy ,

11. Bolonkin A. A., Ultra-Cold Thermonuclear Synthesis: Criterion of Cold Fusion. GS Journal 2015, http://viXra.org/abs/1507.0158, https://archive.org/details/ArticleColdFusionAfterRichard71815.

12. Bolonkin A.A., Transfer Electricity in Outer Space, Paper AIAA-2007-0590 presented to $45^{\text {th }}$ AIAA Aerospace Science Meeting, 8-11 January 2007, Reno, Nevada, USA. See also in book. See also in book Bolonkin A., New Concepts, Ideas and Innovations in Aerospace, Technology and Human Sciences,NOVA, ISBN-13:978-1-60021-787-6, 2006.Ch.8, pp.115-138.

13. Bolonkin A.A., Simplest AB-Themonuclear Space Propulsion and Electric Generator. arXiv:physics/0701226 (19.1.07), Paper AIAA-2007=4613 presented to $38^{\text {th }}$ Plasmadynamics and Laser Conference in conjunction with the $16^{\text {th }}$ international Conference on MHD Energy Conversion on 25-27 June 2007, Miami, USA. See also book Bolonkin A., Cathcart R., MacroProjects. Environment and Technology, NOVA, 2007, Ch. 7, pp.135-148. ISBN 978-1-60456-998-8. 14.Bolonkin A.A., Transfer Electricity in Outer Space. Presented as paper AIAA-2007-0590 to $45^{\text {th }}$ Aerospace Science Meeting 8 -1 January 2007, Reno, Nevada, USA.

15. Kokoin I.K., (Ed.), Table of Physical Values, Atomizdat, Moscow, 1975. 16. Wikipedia. Interstellar Travel.

\section{References to Part 3}

(see some Bolonkin's articles inhttp://viXra.org/abs/1604.0304;http://Bolonkin.narod.ru/p65.htm, http://arxiv.org search "Bolonkin", and book "Non-rocket Space Launch and Flight", Elsevier, London, 2006, 488 ps)http://vixra.org/abs/1407.0174,

[1] Bolonkin, A.A., (1965a), "Theory of Flight Vehicles with Control Radial Force”. Collection Researches of Flight Dynamics, Mashinostroenie Publisher, Moscow, , pp. 79-118, 1965, (in Russian). Intern.Aerospace Abstract A66-23338\# (English).

[2] Bolonkin, A.A., (1982a), Installation for Open Electrostatic Field, Russian patent application \#3467270/21 116676, 9 July, 1982 (in Russian), Russian PTO.

[3] Bolonkin, A.A., (1983a), Space Propulsion Using Solar Wing and Installation for It, Russian patent application \#3635955/23 126453, 19 August, 1983 (in Russian), Russian PTO.

[4] Bolonkin, A.A., (1983b), Getting of Electric Energy from Space and Installation for It, Russian patent application \#3638699/25 126303, 19 August, 1983 (in Russian), Russian PTO.

[5] Bolonkin, A.A., (1983c), Protection from Charged Particles in Space and Installation for It, Russian patent application \#3644168 136270, 23 September 1983, (in Russian), Russian PTO.

[6] Bolonkin, A. A., (1983d), Method of Transformation of Plasma Energy in Electric Current and Installation for It. Russian patent application \#3647344 136681 of 27 July 1983 (in Russian), Russian PTO.

[7] Bolonkin A.A., (1983e) Method for Transfer of Plasma Energy in Electric Current and Installation for it. Russian patent application \#3601164/25 086973 of 6 June, 1983 (in Russian), Russian PTO.

[8] Bolonkin, A. A.,(1983f), Transformation of Energy of Rarefaction Plasma in Electric Current and Installation for it. Russian patent application \#3663911/25 159775, 23 November 1983 (in Russian), Russian PTO.

[9] Bolonkin, A. A., (1983g), Method of a Keeping of a Neutral Plasma and Installation for it. Russian patent application \#3600272/25 086993, 6 June 1983 (in Russian), Russian PTO.

[10] Bolonkin, A.A., (1983i), Method of Energy Transformation of Radioisotope Matter in Electricity and Installation for it. Russian patent application \#3647343/25 136692, 27 July 1983 (in Russian), Russian PTO.

[11] Bolonkin, A.A., (1983j), Method of stretching of thin film. Russian patent application \#3646689/10 138085, 28 September 1983 (in Russian), Russian PTO.

[12] Bolonkin, A.A., (1987), "New Way of Thrust and Generation of Electrical Energy in Space". Report ESTI, 1987, (Soviet Classified Projects).

[13] Bolonkin, A.A., (1990), "Aviation, Motor and Space Designs", Collection Emerging Technology in the Soviet Union, 1990, Delphic Ass., Inc., pp.32-80 (English). 
[14] Bolonkin, A.A., (1991), The Development of Soviet Rocket Engines, 1991, Delphic Ass.Inc.,122 p. Washington, (in English).

[15] Bolonkin, A.A., (1992a), "A Space Motor Using Solar Wind Energy (Magnetic Particle Sail)”. The World Space Congress, Washington, DC, USA, 28 Aug. - 5 Sept., 1992, IAF-0615.

[16] Bolonkin, A.A., (1992b), "Space Electric Generator, run by Solar Wing". The World Space Congress, Washington, DC, USA, 28 Aug. -5 Sept. 1992, IAF-92-0604.

[17] Bolonkin, A.A., (1992c), "Simple Space Nuclear Reactor Motors and Electric Generators Running on Radioactive Substances", The World Space Congress, Washington, DC, USA, 28 Aug. - 5 Sept., 1992, IAF-92-0573.

[18] Bolonkin, A.A. (1994), "The Simplest Space Electric Generator and Motor with Control Energy and Thrust", 45th International Astronautical Congress, Jerusalem, Israel, 9-14 Oct., 1994, IAF-94-R.1.368 .

[19] Bolonkin A.A., (2003), Optimal Inflatable Space Towers with 3 - 100 km Height, JBIS, Vol.56, No.3/4. 2003, pp. 87 - 97.

[20] Bolonkin A.A., (2003), Hypersonic Space Launcher, Actual Problems of Aviation and Space Systems, Kazan, 8 (15), pp.45 - 68.

[21] Bolonkin A.A., (2003), Asteroids as Propulsion System of Space Ships, JBIS, Vol.56, No.3/4, pp. 98 -107.

[22] Bolonkin A.A., (2003), Non-Rocket Transport System for Space Travel, JBIS, Vol.56, No. 7/8, pp. 231 - 249.

[23] Bolonkin A.A., (2004), Hypersonic Gas-Rocket Launcher of High Capacity, JBIS, Vol.57, No.5/6, pp.162 - 172.

[24] Bolonkin A.A., (2004), Kinetic Space Towers and Launchers, JBIS, Vol.57, No.1/2. 2004, pp. 33 - 39.

[25] Bolonkin A.A., (2004), Multi-Reflex Propulsion Systems for Space and Air Vehicle and Energy Transfer for Long Distance, JBIS, Vol.57, No.11/12. 2004, pp. 379 - 390.

[26] Bolonkin A.A., (2005), Electrostatic Solar Wind Propulsion System, AIAA-2005-3653. 41-st Propulsion Conference, 10-12 July, 2005, Tucson, Arizona, USA.

[27] Bolonkin A.A. (2006), Electrostatic AB-Ramjet Space Propulsion, AIAA-2006-6173, AIAA/AAS Astrodynamics Specialist Conference, 21-24 August 2006, USA. AEAT, Vol. 79, No. 1, 2007, pp. 3-16.

[28] Bolonkin A.A., (2006), Optimal Space Tower (Mast), Presented as paper AIAA-2007-0367 to 45th AIAA Aerospace Science Meeting, 8 - 11 January 2007, Reno, Nevada, USA. (See details in author's works: AIAA-2006-4235, AIAA-2006-7717). http://arxiv.org.

[29] Bolonkin A.A., (2006), Linear Electrostatic Engine, Presented as AIAA-2006-5229 for 42 Joint Propulsion Conference, Sacramento, USA, 9-12 July, 2006. http://arxiv.org. Search "Bolonkin".

[30] Bolonkin A.A., (2006), Non-Rocket Space Launch and Flight, Elsevier, London, pp. 488. Contents is in http://Bolonkin.narod.ru/p65.htm.

[31] Kikoin I.K., (1976), Table of Physical Magnitudes, Moscow, Atomic Publish House (in Russian).

[32] Fedorov V.D., (1981), Basis of Rocket Flight, Moscow, Nauka (in Russian).

[33] Landis G.A., (2004), Interstellar Flight by Particle Beam, ActaAstronautica, Vol. 55, pp.931 - 934.

[34] Bolonkin A.A., New Concepts, Ideas and Innovations in Aerospace, Technology and Human Sciences, NOVA, 2006. ISBN-13: 978-1-60021-787-6. Ch.3.http://viXra.org/abs/1309.0193,

[35] Bolonkin A.A., Femtotechnologies and Revolutionary Projects. Lambert, USA, 2011. 538 p. 16 Mb. ISBN:978-3-8473-0839-0.http://viXra.org/abs/1309.0191.

[36] Bolonkin A.A., Innovations and New Technologies (v2). Lulu, 2013. 465 pgs. 10.5 Mb, ISBN: 978-1-31262280-7. https://archive.org/details/Book5InnovationsAndNewTechnologiesv2102014/ 


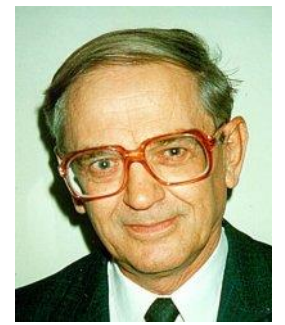

\section{Short biography of Bolonkin, Alexander Alexandrovich}

Alexander A. Bolonkin was born in the former USSR. He holds doctoral degree in aviation engineering from Moscow Aviation Institute and a post-doctoral degree in aerospace engineering from Leningrad Polytechnic University. He has held the positions of senior engineer in the Antonov Aircraft Design Company and Chairman of the Reliability Department in the Clushko Rocket Design Company. He has also lectured at the Moscow Aviation Universities. Following his arrival in the United States in 1988, he lectured at the New Jersey Institute of Technology and worked as a Senior Scientist at NASA and the US Air Force Research Laboratories. Bolonkin is the author of more than 250 scientific articles and books and has 17 inventions to his credit. His most notable books include The Development of Soviet Rocket Engines (Delphic Ass., Inc., Washington , 1991); Non-Rocket Space Launch and Flight (Elsevier, 2006); New Concepts, Ideas, Innovation in Aerospace, Technology and Human Life (USA, NOVA, 2007); MacroProjects: Environment and Technology (NOVA, 2008); Human Immortality and Electronic Civilization, 3-rd Edition, (Lulu, 2007; Publish America, 2010):Life and Science. Lambert Academic Publishing, Germany, 2011, 205 pgs. ISBN: 978-3-8473-0839-3. http://www.archive.org/details/Life.Science.Future.biographyNotesResearchesAndInnovations; Homepage: http://Bolonkin.narod.ru .

\section{To be continued in the next issue of the "Intellectual Archive"}




\title{
The International Search of Persons Committed a Terrorist Act
}

\author{
Matchanov Alimjan Atabaevich \\ Head of the Department of Theory and Practice of Human Rights of the MIA \\ Academy of the Republic of Uzbekistan, Tashkent, Cand.Sc., \\ Associate Professor
}

\begin{abstract}
The article addresses on the issues related to the need to improve the search for terrorists and extremists, shows the main directions of the search activity of law enforcement agencies, examines the specifics of the criminal procedure, criminalistic support, operational tracking and international legal regulation of the search for hiding terrorists and extremists.
\end{abstract}

At the same time, the article emphasizes that the knowledge of the bases of cooperation and coordinated actions of law enforcement agencies, international organizations in the implementation of the search is a necessary condition for the successful search of hiding terrorists.

According to the author, it is necessary to know the features of the criminal procedure order, criminalistic tactics of international search of persons committed a terrorist act.

Keywords: terrorist act, terrorism, law enforcement, criminal, international crime, attack, international cooperation

The act of terrorism is considered as the international crime in the following cases: a) if the criminal and the victims are nationals of one country or different countries, but the crime has been committed outside; b) if the attack was committed against persons under international protection; c) the attack setup is at one country and it is committed in another country; d) if terrorist act is committed at one country, but a terrorist is hiding in another country, and the point on his extradition is raised.

Acts of international terrorism involve senseless loss of life, disrupt the normal diplomatic activities of states and their representatives and impede the implementation of international contacts, meetings, and transport links between the countries. This act is used as an instrument of political struggle at the most reactionary surrounding, parties and criminal organizations. There can be international, national and state terrorism.

If we address to the origin and the history of formation of international concerted actions against international terrorism, these actions have been started in the 30 s of the last century. For example, in 1934 year the following definition of terrorism was interpreted at the Conference for the Unification of Criminal Law in Madrid: "the application of any means to spread terror among the civilian population in order to destruct any social organization". 
In 1937 year more than 20 countries have signed the Convention on the Prevention and Punishment of Terrorism. Here the term terrorism means "criminal acts against the state, which pursue the purpose to cause threats in certain people or among the population" (article 1). These included acts against life, health and freedom of heads of states, persons enjoying prerogatives of heads of state, their hereditary or designated successors; spouses of these persons; persons exercising public functions, the acts committed in connection with their functions; and the destruction of or injury to public property or property of another State; the intention to achieve human deaths through the creation of a common danger, the facts of production, purchase, storage, supply of weapons, explosives or other harmful compounds for committing these crimes [1].

Terrorism acts are prohibited at the time of armed conflicts according to the rules of international humanitarian law, including according to the provisions of the 1977 Additional Protocols to the Geneva Conventions on the Protection of War Victims, 1949.

Subsequently the frameworks for international cooperation in fighting against international terrorism started to be expanded. The UN Special Committee was established. It coordinates the activities of states focused on the study and eliminating the causes of terrorism and on the fight against it. Upon its initiative, the UN General Assembly has repeatedly condemned acts of international terrorism, pointed at the inadmissibility of its broad interpretation, and in 1984 it adopted a special resolution on inadmissibility of the policy of state terrorism and any states' actions aimed at destructing the socio-political system in other sovereign states.

In December 1973 the UN General Assembly adopted the Convention on the Prevention and Punishment of Crimes against Internationally Protected Persons, including diplomatic agents. According to the Article 1 Internationally Protected Persons are heads of states, head of governments during their stay in a foreign country, the minister of foreign affairs, family members who accompany these persons abroad; representative of state or other officer entitled to have a special protection; officer or agent of the international organization and family members living with them [5].

Measures to prevent the international terrorism and strengthen the fight against it are provided in decision VIII of United Nations Congress on the Prevention of Crime and the Treatment of Offenders "Measures to combat international terrorism", 1990 and the Convention on the Safety of United Nations and Associated Personnel, 1994. The Convention 
on the Marking of Plastic Explosives (EX) 1991 plays a certain role in the prevention of international terrorism acts. The States have committed to put marking on plastic explosives to detect them in case of terrorist attacks. Within three years their stocks should be destroyed, used or made unusable. Military and police stocks will be disposed within 15 years. Political units combating the international terrorism were included into final documents of the meeting of members of the Organization for Security and Cooperation in Europe (OSCE) in Helsinki, Madrid, Vienna and Paris. Three regional agreements were enacted; 1971 OAS Convention to Prevent and Punish Acts of Terrorism Taking the Form of Crimes against Persons and Related Extortion, if such acts are international; 1977 European Convention on the Suppression of Terrorism; 1987 SAARC Regional Convention On Suppression of Terrorism. The Committee of Foreign Ministers on Terrorism is working in the framework of the European Economic Community (EEC).

Despite the abundance of international legal instruments and agencies coordinating the fight against international terrorism in international law, till this day there is no universal agreement defining the concept of international terrorism, its legal nature and responsibility [2]. There is no the exhaustive list of acts of international terrorism as well.

In virtue of the analysis of international agreements, the following list of such acts can be defined: a) explosions of embassies, missions, representative offices and headquarters of international organizations; b) acts of sabotage in the streets, airports, railway stations, cultural centers, industrial buildings, places for commercial and professional activities, which are related to the destruction or damage to property and causing injury or death of people; c) the deliberate use of explosive devices built into parcels, packages, letters and other postal items; d) any act of sabotage against public buildings; e) conspiracy to commit acts of international terrorism and complicity in any form, etc. According to different sources the acts of international terrorism include: hostage, piracy, acts against the safety of civil aviation, and illegal seizure and use of nuclear material. However, due to their particular international threat, prevalence and diversity in forms of commission, to deal with them states are adopting special conventions and devote some of them to certain crimes of international concern.

Thus, the following intentional acts are considered as the international terrorism: murder, kidnapping or other attack against the person or liberty of these persons; violent 
assault against official premises or vehicle of such person, if the attack is dangerous to such person or his/her liberty; threat, attempt or complicity in such attack.

At the present time in the modern world the acts of international terrorism are committed. The persons who committed these crimes are on the wanted list. Now a scientific study of this problem is urgent. Knowledge of fundamentals of criminal investigation theory and practice represent a great importance for successful solution of problems related to the investigation of acts of international terrorism.

In this regard, the use of methods, techniques, ways of search, including the most important rules of investigative activities, will create all necessary conditions for arresting terrorists.

Successful implementation of investigative activity has significance in international area as well, because more and more crimes are transnational and are moving beyond national boundaries acquiring international dimension.

International search, by definition, represents a set of investigative, information and reference and other activities by the competent authorities of the state, which is the initiator of investigation and of foreign countries, where the activities are aimed at detection, arrest and surrender (extradition) of wanted criminals [6].

One of the main types of international search is a search for a person committed an act of terrorism and who is hiding from the law enforcement agencies. To implement successfully the international search for a person fleeing from justice, law enforcement agencies should always remember about the necessity to take preventive measures. It may be achieved due to immediate application of urgent, initial measures of the search for those who have committed an act of terrorism.

The practice of investigating authorities shows that wanted people often leave for foreign countries and stay there illegally until good days to avoid criminal liability. That is why, a long-term uncertainty relating to the place of location of such people and the absence of any effective investigation are the evidence of poor and inefficient investigative activities.

For this purpose, it is important to have knowledge of theoretical, practical and institutional fundamentals of international investigation in course of detection and investigation of acts of international terrorism. The methods, techniques, ways of the international investigation, which are specified in the regulations, including the most 
important rules of investigative activity, establish organizational and legal basis to improve the activity.

Currently, in all countries, where the legal system is developed, "there is a persistent search for the most efficient forms of detection and investigation of crimes" [3].

The system of investigative activities included into the national criminal procedural law and international agreements is applied to find the location of wanted criminals. If a person can escape beyond one state, according to universally recognized rules of international law, the provisions of various conventions, bilateral or multilateral treaties may be applied and international search for criminals may be implemented.

International search for a person committed terrorist crimes is one of the activities of law enforcement agencies and is conducted provided by a strict adherence to national criminal procedural law and international treaties and agreements.

This kind of international investigation, except for as provided by national legislation, is based on various sources of international law, including on international agreements. Consequently, when declaring the search, if the fact of leaving by a wanted accused person for abroad is be ascertained and his/her exact location is unknown, the interstate or international search will be declared.

The applicable procedure for placing a person to the above mentioned wanted list does not eliminate the possibility to send to the National Central Bureau of International Police of the country a request for individual search within their territory, if there is credible information on relationships of a wanted person in this country. Account must be taken of the fact that wanted people can stay both within the territory of the Commonwealth of Independent States (CIS), and in other foreign countries.

In terms of the scale of investigation the international search can be divided into interstate (within the CIS countries) and the international (through the Interpol). Therefore, a person, who committed a crime, can be placed both to interstate and international wanted list.

According to the international agreement of the Commonwealth of Independent States, which provides the international search to be conducted on the basis of the Treaty of CIS member states on the International Search, and which was signed in Moscow on December 10, 2010 year [4], entered into force in the Republic of Uzbekistan on 24 August, 2011.

If we refer to the experience of the United States in conducting the search for criminals fleeing from justice, we can state that there is a criminal record, which is called "criminal 
identification system" and it is very comprehensive, because all participants of the criminal process are registered, including the person, who committed a crime. These persons are registered by their fingerprints, appearance, and not only by using the description of these features, but by using the photographs and recognizing a criminal according to the method of crimes committing by him/her. Fingerprint records are conducted using 10-fingerprint identification system.

This allows to monitor continuously and accurately the occurrence of information on fingerprints of a wanted person throughout the United States, to determine the location of fingerprints, which are a "point of reference" for detection and arresting the accused person, because it is a place of possible location of the wanted person. It has a direct relevance for determining the boundaries and scope of investigation activities, and, in our opinion, in these terms the organization will increase the efficiency of criminals search.

The study of international best practices in using modern procedural and criminalistic methods for organization of investigative activities by national law enforcement agencies, their interaction with international law enforcement agencies in conducting the investigative function, shall allow to conclude that it is characterized by the following trends of development and prospects of organization of the search for persons who have committed a crime:

1) computerization of the search for criminals through the Internet or another international information network;

2) creation of international system of information exchange among various law enforcement agencies, including international organizations, on the basis of computer technologies providing the immediate transmission of information from the addressee to the consumer, including the protection of the system against unauthorized access or interception;

3) large-scale re-equipment of investigation units and investigative agencies on the basis of international agreement between governments, intergovernmental organizations with more powerful and faster, mobile technical means;

4) universal international computerization of all types of identification: habitologic, phonoscopic, fingerprint, trasological, audio and videoscopic, etc. Establishment of specific international information retrieval systems to be used for investigations by law enforcement agencies on the basis of these types of identification; 
5) the establishment, on an international scale, of the electronic cartographic system, delimiting the details and scope of investigative activities related to a person fleeing from justice, including the exact definition of his/her domicile, place of work, information on his/her family, place the possible location, residence of former accomplices, place of residence and work of close friends, and the place, where criminals can meet, provided by the availability per each territory unit of the list of wanted people related to the wanted accused person, including the degree of operational support of the area, where a wanted criminal may hide;

6) considering the possibility that a wanted person may change his/her appearance by a plastic or other type of surgery, it is necessary to introduce to the work of law enforcement officers, who carry out the search, the possibility to scan the retina of the criminal to identify the person in case of his/her charge or arrest.

Currently, there is an urgent need for adopting international agreements and legislative measures to optimize the criminal procedural law, which is governing the organization of the search for criminals, taking into account current trends in forensic science development and technological progress.

Thus, the international search for wanted persons, who committed a crime, should proceed from the optimization of work of the national law enforcement agencies and international organizations to implement systematic, effective activities. For this purpose some aspects should be taken into account, including:

- international search for wanted persons, who committed crimes in current conditions of development and intensification of international relations, is one of the most important areas of cooperation between states in the fight against crimes;

- international search is a complex investigation, information and reference and other activities by the competent authorities of the state, which is the initiator of investigation and of foreign countries, where the activities are aimed at detection, arrest and surrender (extradition) of wanted criminals;

- considerations of the national criminal procedural law, which is governing the procedure for relations with law enforcement agencies of foreign states on legal assistance in criminal matters and extradition of criminals;

- improving the organizational basis of law enforcement agencies cooperation with the Interpol NCB of the country; 
- insertion of data on internationally wanted criminals into Internet database, not only into the Interpol General Secretariat website, but into websites of national law enforcement agencies and the media.

\section{References}

1. Vashchenko Iu.V. Opyt bor'by s terrorizmom za rubezhom. [Experience in the fight against terrorism abroad]. In "Prestupnost' i zakonodatel'stvo". Moscow, 1999, P. 379.

2. Emel'ianov V.P. Terrorizm kak iavlenie i kak sostav prestupleniia.[Terrorism as a phenomenon and as a component of a crime] Khar'kov: "Pravo", 1999. P. 12.

3. Kartokhina O.A. Sledstvie: vchera, segodnia, zavtra. [Investigation: yesterday, today, tomorrow ] // Rossiiskii sledovatel'. 2005. No 1. P. 3-4.

4. Collection of International Treaties of the Republic of Uzbekistan. 2012, No 1-2.

5. International Terrorism and World Security, L., 1998. P. 14.

6. Putova I.V. Mezhdunarodnyi rozysk prestupnikov: Pravovye, organizatsionnye, operativno-takticheskie aspekty: [International search for criminals: Legal, organizational, operational-tactical aspects] avtoref. dys. ... kand. jurid. nauk. Moscow, 2001. 23 p.

\section{Translation of the Title, Abstract and References to the Author's Language}

1. Ващенко Ю.В. Опыт борьбы с терроризмом за рубежом. Преступность и законодательство. Москва. 1999. С. 379.

2. Емельянов В.П. Терроризм как явление и как состав преступления. Харьков: Право. 1999. С. 12.

3. Картохина О.А. Следствие: вчера, сегодня, завтра. Российский следователь. 2005. № 1. C. 3-4.

4. Collection of International Treaties of the Republic of Uzbekistan. 2012. No 1-2.

5. International Terrorism and World Security, L., 1998. P. 14.

6. Путова И.В. Международный розыск преступников: Правовые, организационные, оперативно-тактические аспекты: автореф. дис. ... канд. юрид. наук. Москва, 2001. 23 с. 


\title{
The Evolution of Secondary School Reforms in Ukraine in the $2^{\text {nd }}$ Half of the $19^{\text {th }}$ - the Beginning of the $20^{\text {th }}$ Centuries
}

\author{
Nataliya Vykhrushch \\ Dept. of Psycology and Social Work, \\ Ternopil National Economic University \\ Ternopil, vul. Lvivska 11, Ukraine \\ v25natalka@yahoo.com
}

\begin{abstract}
The article deals with evolution of secondary school reforms in Ukraine in the $2^{\text {nd }}$ half of the $19^{\text {th }}-$ the beginning of the $20^{\text {th }}$ centuries. Secondary school reforms in Ukraine were particularly dynamic in the investigated period due to rapidly changing society needs as a result of political, economic and cultural changes. In this period Ukrainian territory was under the rule of two empires. The peculiarities of secondary school reforms on the territories that were subject to both the Austrian Empire and Russia have been singled out. The directions, strategies and principles of innovations in the system of secondary schools on both territories have been compared.
\end{abstract}

Key words: education, secondary, school, gymnasium, schoolchildren.

\section{Introduction}

Nowadays introduction of secondary school reforms is vital for modern education quality improvement. Effective contemporary educational reforms are impossible without taking into account positive experience of previous generations. The educational processes of the past centuries had direct influence on the development of schooling in Ukraine in the second half of the 19th - the beginning of the 20th centuries. The secondary school reforms in Ukraine were particularly dynamic in the investigated period due to rapidly changing society needs as a result of political, economic and cultural changes. In this period Ukrainian territory was under the rule of two empires. East Halychyna, North Bukovyna and Zakarpattia, were subject to the Austrian empire, other territories of Ukraine stepped back to Russia and got the name of Naddniprianschyna.

The aim of the research is to trace the evolution of secondary school reforms in Ukraine in the 2nd half of the 19th - the beginning of the 20th centuries.

\section{Materials and Methods}

In the process of research the following methods of data collection have been used:

Bibliographic search (the study of archive and library catalogues, library stocks, descriptions of bibliographic editions; reviewing, special purpose analysis of Ukrainian historical, pedagogical literature and press of the investigated period); 
$\checkmark \quad$ Chronological, comparative and statistical analyses (curricula, programs, textbooks, school legislation data treatment);

$\checkmark \quad$ Systematization and theoretical generalization (formulation and substantiation of conclusions as a result of conducted research).

\section{Results and Discussion}

Russian government simultaneously carried out both educational reforms and repressions against Ukrainian culture.

In the reign of Mykola I (1825-1855) educational policy was determined by complete oppression of personality of both teacher and student. A teacher had to blindly obey the authority, and a student had to be fully devoted to Orthodoxy, autocracy and Russian people. The director of gymnasium provided the curator of educational district with the following information about every undergraduate: the language they speak, whether they demonstrate improvements in Russian, their attitude to religion, whether they are not inclined to freethinking, whether they are devoted to Russia (Siropolko, 2001:305).

The curator of Kyiv school district D. Bibikov kept teachers and schoolchildren under almost police supervision. In 1839 he ordered all citizens and police representatives to closely follow teachers and schoolchildren and to inform on them directly to him (Siropolko, 2001:306).

In 1856 a well-known surgeon, Professor Mykola Pirohov, wrote the article "Voprosy zhyzni" that was published in the magazine "Morskoi Sbornik". In the article he stated that school must prepare a child to be an individual, thus, proclaiming a panhuman ideal of education. The article was a great success and in September, 1856 Mykola Pirohov became the curator of Odesa school district, and in 1858-1861 - the curator of Kyiv school district. His articles always brought novelty into the school structure of tsarist Russia. He limited the use of corporal punishments, introduced literary conversations of schoolchildren in gymnasia, trial by fellow schoolchildren in higher forms of gymnasia, increased the importance of a teacher at school (Siropolko, 2001:306-307).

The successors of M. Pirohov were distinguished by implacable hatred to Ukraine. Oleksandr Shirinskyi-Shimanov was especially marked by denunciation for M. Drahomanov as ukrainophile, by burning 500 copies of fables collections by L. Hlibov, withdrawal of the best 
works in natural sciences, physiology and geology from the gymnasia libraries (Siropolko, 2001:309-310).

In secondary schools of Naddniprianschyna Russian curricula and programs were used and the subjects were taught in Russian. Starting from the second half of the $19^{\text {th }}$ century Russian government pursued a policy of continuous Russification of Ukrainian culture and education. Both Valuievskyi (1863) and Emskyi (1876) decrees forbade publication of Ukrainian scientific, artistic and pedagogical editions, Ukrainian theatrical performances, teaching in Ukrainian in primary school. Furthermore, in 1847 a secret circular appeared aimed at withdrawal of "Story of Ukrainian Nation" (1846), "Ukraine" (1843) by P.Kulish, "Kobzar" by T. Shevchenko, "Ukrainian ballads" by M. Kostomarov and works by M. Chernyshenko from the gymnasium libraries of Kyiv educational district, as they were considered untrustworthy (Babina, 2000:5).

The Regulation of 1864 defined the following types of male secondary schools: gymnasia with the Latin language (50\%), gymnasia with two classical languages (Latin - since the 1st form, Greek, - since the 3rd form) (25\%), real gymnasia without classical languages (25\%) (Siropolko, 2001:313).

Since 1849 bifurcation took place in gymnasia: special lectures were introduced in Russian and Slavic languages, mathematics and legislation for those, who prepared to military service, Latin - for those, who decided to enter the university, Greek - for all interested ones. General subjects from the $4^{\text {th }}$ form were the following: religion, the Russian and Slavic languages, mathematics, physics, geography, history, the German and the French languages, drawing for interested ones. Since 1852 the distribution of subjects in gymnasia was slightly changed: religion, the Russian language, the Latin language (from the $2^{\text {nd }}$ form) the Greek language (from the $4^{\text {th }}$ form), geography, history, mathematics, the German language and the French language, calligraphy, drawing for interested ones (Siropolko, 2001:305-306).

Statute of gymnasia and progymnasia (1864) stated equality in secondary education for all people, regardless of their social statues and beliefs. According to it all gymnasia were divided into classical and real with 7 years of studies. Classical gymnasia provided education in humanities that was based on ancient (classical) languages - Latin and Greek. In real gymnasia children had more hours of mathematics and natural history at the cost of hours for humanities. Whereas classical gymnasia graduates had the right to enter universities without 
exams, real gymnasia graduates could only enter higher technical institutions. According to the Statute 4-year educational establishments called progymasia appeared. They corresponded to the first four forms of classical gymnasia. Progymnasia graduates could enter the fifth form of classical gymnasia.

In accordance with Regulations of 1871 all gymnasia became classical. The term of studies lasted 8 years (2 years in seventh form). A considerable emphasis was placed on the study of ancient languages; cosmography was substituted by mathematical geography. The amount of hours for calligraphy, drawing, drafting, history and religion was diminished. Once again the study of logic was introduced. Mechanical learning and cramming was put in the heads of children in gymnasia, every independent thought was repressed. Denunciations and whispering were encouraged.

In 1860 The Institute of Noble Maidens in Kyiv was turned from 6-year into 7-year school, and in 1878 it already accepted the girls of lower classes. The course of female gymnasia lasted eight years. The eighth form was aimed at preparation of teachers and home nursery governesses. In the program of studies instead of classical languages that were studied in male gymnasia natural history was introduced (Siropolko, 2001:325-326).

The Regulation "About the reduction of gymnasium education" (1887) is known as The Regulation "about cook-housekeeper's children" limited the access to education for children of working people with the purpose of limiting the amount of students from "ignoble families", as students were considered to be the main driving revolutionary force.

With beginning of a new century the examination process and study of the classical languages were facilitated. Writing examinations in classical languages were cancelled, teachers councils of gymnasia got the right to transfer successful students to the next form without examinations. Latin was cancelled in first and second forms of male gymnasia and progymnasia, and Greek - in the third and fourth. All students of secondary schools with the mark not less than "satisfactory" in every subject were transferred to the next form without examinations (Siropolko, 2001:426).

Revolution of 1905 compelled the Ministry of Education to pay attention to educational needs of population. The draft bill about the implementation of general education was brought before the State Duma and was based on following principles:

$\checkmark \quad$ All children aged 8-11 had to pass a 4-year school course; 
$\checkmark \quad$ School had to provide its services to children in a radius less than $3 \mathrm{~km}$;

$\checkmark \quad$ One teacher mustn't teach more than 50 children;

$\checkmark \quad$ General education had to last for 10 years;

$\checkmark \quad$ School education had to be free.

However, the draft wasn't considered (Siropolko, 2001:427).

On the territories that were subject to both the Austrian Empire the situation was slightly better. Revolutionary events in the Austrian Empire of 1848 speeded up the abolition of serfdom Halychyna. The constitution adopted in Austria outlined favourable conditions for the development of Ukrainian schooling (Vas'kovych, 1996:16). Revolution of 1848 forced the Austrian government to adopt the constitution and give certain facilitations to the people that inhabited the empire. Hence, in 1848 Supreme Ruthenian Council was created in Lviv that came forward for the development of the Ukrainian language and schooling.

Educational policy in Halychyna was determined by Articles 17 and 19 of

Basic Law on the General Rights of Nationals proclaimed the following:

- Knowledge and its teaching were free.

- Every national who had furnished in legally acceptable manner proof of his qualification had the right to found establishments for instruction and education.

- Instruction at home was subject to no such restriction.

- The Church or religious society concerned shall see to religious instruction in schools.

- The right to supreme direction and supervision over the whole instructional and educational system lies with the state (Austria - Basic Law, 1897)

In the end of $19^{\text {th }}$ century Halychyna was one of the poorest in Europe. Absence of basic export commodities such as a wheat or sugar beet and competition from highly industrialized provinces such as Bohemia, Lower Austria and Moravia was one of the biggest economic problems in Halychyna. It remained agrarian society with insignificant stock accumulation, poorly developed domestic trade, low level of urbanization, almost unnoticeable industry, lowest earnings and highest percent of surplus labour force in the empire (Sybtelnyi, 1993:383).

Low level of economy in Halychyna resulted in the fact that at the beginning of the $20^{\text {th }}$ century a considerable industrial centre failed to be formed and the bulk of population $(78,4 \%)$ lived in villages (Blahyi, 1999:8).Many peasants went for seasonal jobs to western provinces of Austria, Hungary, Germany, emigrated to Canada, USA, Brazil and other countries.700-800 
thousand people from Western Ukraine drove out to foreign countries during 1890-1913 (Kondratiuk, 1994:113).

The reform of 1869 helped the development of Halychyna schooling. The government of the Austrian Empire proclaimed free compulsory primary 6-year education, the right to be taught in mother tongue. Communities and religious organizations got the permission to create private schools (Kurliak, 1995:145). However, as a result of poverty many Ukrainian children did not have the opportunity to attend school. Besides, in most schools the studies was conducted in foreign languages: East Halychyna - Polish, North Bukovyna - German, Romanian, Zakarpattia - Hungarian.

Classical gymnasia provided education in humanities. They were the most prestigious. Curriculum of classical gymnasia allocated $35 \%$ of teaching hours to Greek and Latin. Whereas all languages (Ukrainian, German and Polish) accounted for $65 \%$ of teaching hours, only $20 \%$ of teaching hours was allocated to mathematics and natural sciences (Blahyi, 1999:8).

Studies in classical gymnasia lasted for 8 years. Lower gymnasium provided universal education necessary for practical necessities. Higher gymnasium gave an opportunity to enter university.

The list of the subjects taught in classical gymnasia was as follows:

$\checkmark \quad$ Religion - in all forms 2 hours per week ( in the $1^{\text {st }}$ form - catechism, in $2^{\text {nd }}$ and $3^{\text {rd }}$ forms - biblical history, in $4^{\text {th }}$ forms - liturgics, in $5^{\text {th }}$ and $6^{\text {th }}$ forms - dogmatics, in $7^{\text {th }}$ form - ethics, in a $8^{\text {th }}$ form - history of church);

$\checkmark \quad$ Latin - in the $1^{\text {st }}$ and $2^{\text {nd }}$ form 8 hours per week, in $3^{\text {rd }}-8^{\text {th }}$ form 6 or 5 hours per week;

$\checkmark \quad$ Greek - in $3^{\text {rd }}-8^{\text {th }}$ forms 5 or 4 hours per week;

$\checkmark \quad$ Mother tongue - in all forms 3 hours per week;

$\checkmark \quad 2^{\text {nd }}$ new language;

$\checkmark \quad$ Geography and history in all forms 3 hours per week;

$\checkmark \quad$ Mathematics - in all forms 3-5 hours per week;

Natural sciences (Natural history or Physics) -2-4 hours per week;

Philosophical Propaedeutic (Logics and Psychology) - in 7-8 forms 2 hours per week. Other subjects were not compulsory.

Local state and school administration controlled the development of Ukrainian gymnasium education in Halychyna very thoroughly. According to the law of 1867 in existing 
middle educational establishments, except Lviv Academic gymnasium, the Polish language became the language of studies. Opening of new Ukrainian gymnasia could take place only on the basis of separate decision of Galytskyi Sejm. Ukrainian gymnasium couldn't be opened in those cities, where there was no Polish gymnasium, so that Polish children did not attend foreign educational establishment. Such policy resulted in the fact that 41 Polish and only 4 Ukrainian state secondary schools were founded in Halychyna for 40 years. By 1895 there was the only Ukrainian state secondary school - Lviv Academic gymnasium (Blahyi, 1999:19).

Since 1909 real gymnasia and real schools appeared beside classical gymnasia. Less time was dedicated to studies of languages. The Greek language was substituted by the English language or the French language and the teaching hours were halved. Mathematics, natural sciences and descriptive geometry were studied deeply than in classical gymnasia.

In real schools the number of teaching hours for a week was 50 hours less in comparison with classical and real gymnasia. It took place since Latin, Greek and Philosophical Propaedeutic was not taught at all and history hours were diminished. Instead, teaching hours for mathematics and drawing doubled and teaching hours for physics and chemistry increased as well (Blahyi, 1999:22).

In 1897 women got the right to enter universities. Female lyceums with 6-year term of studies appeared since 1900. They were aimed to provide women with appropriate general education, higher than in primary schools and to prepare them to professional education. Special emphasis was put on modern languages and literature. Beside compulsory subjects (religion, Polish, two modern European languages, history, geography, mathematics, natural history) women also studied optional subjects (singing, stenography, typewriting, "women works"). However, lyceums provided lower level of knowledge compared to gymnasia and after graduation women didn't have the right to obtain higher education. Consequently, feminist societies started movement for state gymnasia for women. The government was indifferent to such demands and no gymnasium was founded by World War I. Nevertheless, the reform of lyceums that divided the studies into lower (4-year) and higher (2-year) levels took place in 1912. For lyceum students that wanted to continue education at universities 2-year courses were organised to prepare them for maturity certificate exams. Thus, lyceum graduates could get the certificate of secondary education that was equal to gymnasium or real school certificate and gave them possibilities to enter higher educational establishments (Blahyi, 1999:24-25). 
An increase, though very slow, of the number of state Ukrainian gymnasia contributed to the fact that higher percent of Ukrainians had the opportunity to get secondary education in mother tongue. During 1900-1901 schoolyear 43,9\% of all Ukrainian gymnasium students studied in Ukrainian gymnasia, whereas in 1910-1911 schoolyear this index grew to 57,5\% (Blahyi, 1999: 20).

\section{Conclusions}

On the whole, the reforms of secondary school education that took place in the $2^{\text {nd }}$ half of $19^{\text {th }}$ - the beginning of $20^{\text {th }}$ centuries represented certain achievements. However the imperial governments of the Austrian Empire and Russia were not interested in the development of Ukrainian culture, being rather afraid of an increase of national consciousness of Ukrainian people.

On the territories that were subject to both the Austrian Empire the situation was slightly better, as there was a possibility to study mother tongue. The number of secondary schools grew slowly and didn't meet the needs of all children wishing to enter it. Ukrainian people realized that without the change of the political regime it was impossible to hope for national revival and development of the Ukrainian culture.

Deviation from classical learning and advocacy of real sciences were closely interconnected with growing necessities of society for professional intelligentsia services.

\section{References}

1. Austria - Basic Law on the General Rights of Nationals [Online]. Available: http://www.servat.unibe.ch/icl/au03000_.html\#A009_. [Accessed Aug.1, 2018].

2. Babina O.I. Stanovlennia ta rozvytok himnaziynoyi osvity v Ukraini (v kintsi XIX- na pochatku XX stolittia) [Formation and development of gymnasium education in Ukraine (in the end of 19th - the beginning of 20th centuries]: avtoref. dys. ... kand. ped. nauk: 13.00.01 Kyiv. 200019 p.

3. Blahyi V.B. Shkilnytstvo v Halychyni na pochatku XX stolittia: istoryko-sotsiolohichnyi aspect [Schooling in Halychyna at the beginning of 20th century: historical and social aspects]. Lviv. 1999. 76 p.

4. Kondratiuk K. Istoriya Ukrayiny. Vid polovunu XIX stolittia do 1917 roku [History of Ukraine in the 2nd half of the19th century - 1917]. Ternopil. 1994. 175 p.

5. Kurliak I. Narodne Shkilnytstvo $v$ Halychyni ( $v$ druhiy polovyni XIX- na pochatku XX stolittia) [Folk Schooling in Halychyna (2nd half of 19th - the beginning of 20th centuries)]. Pedahohika i Psykhologia: zbirnyk naykovych prats. 1995. Vol.1. PP. 144-151. 
6. Siropolko S. Istoriya osvitu v Ukrayini [History of education in Ukraine]. Kyiv. 2001. 912 p. 7. Sybtelnyi O. Ukraina: istoria [History of Ukraine]. Kyiv. 1993. 720 p.

8. Vas'kovych H. Shkilnytstvo v Ukraini (1905-1920) [Schooling in Ukraine (1905-1920)]. Kyiv. 1996. 359 p. 
DOI 10.32370/2018_07_76

\title{
How to Increase the Efficiency of Teaching Calculus I at College Level: Student-Centered Approach
}

\author{
Anastasiya Yakunina, Ph.D. \\ Associate Professor of Mathematics \\ Voorhees College, 481 Porter Dr, Denmark, SC 29042 USA \\ anastasiya.yakunina@yahoo.com,ayakunina@voorhees.edu
}

\begin{abstract}
The article is dedicated to the problem of optimization of teaching Calculus I in a college. The most important factors that influence the efficiency of a teaching process (a composition of the class, students' background in Mathematics, correct choice of the assignments for the students, etc.) are presented. Concrete instructions for successful teaching Calculus I are given. Special attention is paid to a student-centered approach that is considered as a useful tool for an improvement of the results of teaching Mathematics at college level. All conclusions and recommendations are based on the results of modern research in Education and on the author's teaching experience (11years).
\end{abstract}

Keywords: Teaching Calculus, teaching Mathematics in college, individual approach, effective teaching, student-centered education

In the beginning of teaching Calculus I in college there're some important factors that you have to take into consideration if you want to succeed.

A composition of the class is one of them. Generally speaking, all students have different backgrounds in Mathematics. For example, some of them studied only Pre-Calculus, while the other students took one-year course of Calculus at high school. So if you have a miscellaneous composition of the class, it's always a good idea in the beginning of the study of the course to review the most important basic concepts not only of Calculus but of Pre-Calculus as well. Also you can give your students some tasks (tests, home assignments, etc.) to find out what their level of mathematical knowledge is. In accordance with the results you can plan and correct your teaching process, to render individual help and tutoring to the students who need it (not only at class but during your office hours as well).

An instructor should understand how important it is to maintain the students' interest at high level during a class session (this refers especially to teaching Mathematics but at the same time is more difficult to realize in practice than when teaching, for example, History). Review of the basic concepts can be boring for those students at your class who already know "all this stuff". A good solution of this problem is to make such students your helpers during class session. For example you can ask them to "remind" you of some useful formulas instead of 
writing them down by yourself. Of course even the best students sometimes make errors so you should be ready to correct them if needed. It's of the utmost importance to keep your students willing to assist you during the class, to make them actively involved into learning process. It's possible to attain only if an instructor is polite and friendly with his/her students. So if you encourage your students to help you during class and they made some errors, you should never criticize them rudely and don't allow other students in class to do it, because in this case the students (especially those of them who are shy) will lose their self-confidence and probably will never help you again, so you will "lose" them. Instead of accusation of the lack of knowledge, correct the student politely if he/she is wrong and at the end of the discussion thank the student for his/her help.

In accordance with the student-centered theory of teaching, maintaining a friendly, comfortable atmosphere during every class session is one of the essential factors that allow you to succeed in teaching not only Calculus but all disciplines [1].

In the beginning of a study of Calculus I it's essential to make your students understand how important it is for them to have well-developed skills of basic differentiation. You have to emphasize that studying Calculus I supposes good knowledge of the basic properties of differentiation so they won't succeed in Calculus I if they don't remember the most significant formulas for differentiation (of the product, quotient and the chain rule) and the formulas for differentiation of basic algebraic and transcendent functions.

So one of the important factors of successful teaching Calculus I is to dedicate 1-3 first lectures to remind your students of the basic properties of derivatives and of how to use them in practical differentiation [2].

Explain to your students that there can't be too much practice with differentiation. Give them as many examples and problems as possible (it will be much more effective if you ask your students to "help" you to solve them in class). Collective discussion is one of the most useful methods that can be applied here. Encourage your students to ask you any questions in the process of solution if they have them. Also you should ask your students if they need additional examples. When the problem is solved, don't forget to discuss a solution briefly once again and stress the key points of it to your students. The practice of teaching Calculus proves that it's more beneficial to solve only 5 problems but to explain them to the students thoroughly than to solve 10 problems quickly but without proper explanation [3]. 
Emphasize that you'll apply the formulas for differentiation throughout the entire course and that problems will become much more difficult very soon. Encourage your students to apply for help if they still don't feel that they mastered the basic differentiation of the functions. Don't study new stuff until you're sure that your students remember all the necessary formulas and can apply them quickly (almost automatically).

It's very helpful to give your students a test or a quiz after 1-3 introductory class sessions. If the students demonstrate sufficient understanding of the basis of differentiation, you can start to study the formal definition of the limit. Actually it's not necessary to require memorizing this definition because it's quite difficult and many students will forget it sooner or later. It's probably more useful to give your students some graphic examples of the limits of the functions, to show the difference between $\lim _{x \longrightarrow a-0} f(x), \lim _{x \longrightarrow a+0} f(x)^{\prime} f(a) \underset{\text { and }}{\lim _{x \longrightarrow a} f(x)}$ (consider different cases).

Also solve some quick problems for the limits of the following types: $m / 0,0 / m, \infty / \infty$, $0 / 0,0 / \infty, \infty / 0$ ( $m \in \mathrm{R}, m \neq 0 ; m$ can be any real number, e.g. you can use 1 for $m$ ). Don't be too concerned about the application of the strict definition of the limit but rather try to help your students to understand the gist of the matter. Such problems are not only interesting for students, they really help to develop their logic and mathematical intuition as well.

For many students Calculus I is more difficult discipline than Pre-Calculus, therefore it's very important to make sure that your students really understand the stuff that you teach. Mathematics is quite complex discipline, and just memorizing formulas, definitions and algorithms never brings good results if the students don't have a true understanding of learning material.

So, it's very beneficial to give your students tests and quizzes after they studied every important concept. Of course a teacher must keep a sense of proportion about assignments. For instance, some instructors give tests to their students in every other class session that is timeconsuming and stressful for many students. One quiz per 4-5 class sessions is usually quite enough to get a sufficient feedback.

Alongside with quizzes and tests during class you can ask your students some quick questions about the stuff that they're currently studying just to make sure that they pay attention to your lecture and that they understand the learning material correctly. It's a very effective 
practice because it provides an instant feedback and you can correct your teaching immediately (e.g. you can give your students some additional explanations and examples). Furthermore asking quick questions during class doesn't take much time; it's usually interesting for students, really involves them into learning activity and isn't very stressful for them.

A practice of teaching Calculus I shows that an instructor should not rely on the results of homework too much because you never can be sure that the student accomplished it himself. Often students ask their friends and classmates to help them with homework. It refers especially to the students with poor background in Mathematics who actually need your help more than others, so homework hardly can provide a valid feedback. It's better to consider homework just as an additional practice for your students.

So we discussed some important factors that an instructor has to take into consideration to teach Calculus I successfully. One of the exciting opportunities for any instructor is not only to teach Mathematics but to learn HOW to teach!

\section{References}

1. Friedberg, Solomon. Teaching Mathematics in Colleges and Universities: Case Studies for Today's Classroom / Student ed. Conference Board of Mathematical Sciences, Rhode Island. 2001.

2. Kelton, Suzanne. An Introduction to Teaching Mathematics at the College Level / Assumption College. Available: https://www.ams.org/profession/career-info/gradschool/Kelton-TEACH.pdf

3. Krantz, Steven. How to Teach Mathematics. $3^{\text {rd }}$ edition. American Mathematical Society, Rhode Island, 2015, P. 26. 


\title{
The Peculiarities of Forming Value Attitude to Another Person in Teenagers of Boarding Schools
}

\author{
Filonenko Lesia \\ ORCID: https://orcid.org/0000-0002-1969-8387 \\ Postgraduate student \\ Vinnytsia Mykhailo Kotsubynskyi State Pedagogical University (Ukraine)
}

\begin{abstract}
The article discusses peculiarities of the formation of value attitude to a person in teenagers of orphan boarding schools.

The study of peculiarities of the formation of value attitude to a person in teenagers of comprehensive orphan boarding schools demands taking into account two factor groups which directly influence this process.

To the first group, the author refers the following: sensitivity of early teens to the formation of value attitude to a person; the potential of after class activities of comprehensive orphan boarding schools to form value attitude to a person (the possibility to make a focused effort to form value attitude to a person; to have a timely diagnosis of the degree of the formation of value attitude to a person; a continuous communication between students and their pedagogues, it creates possibilities of humanising academic process, which in its turn, demands encouraging the formation of humanistic focus of a personality, satisfying the needs of teenagers in their making a free choice of activities; students involving in a humanistic activity which can enrich the experience of moral conduct).

The second group of factors greatly complicate the process of the formation of value attitude to a person in teenagers of comprehensive orphan boarding schools. They are social orphanage; peculiarities of organisational and pedagogical functioning of comprehensive orphan schools (excessive oversight of boarders' life activities; the forced adaptation to a big number of peers; the decrease of intimacy and trust in the communication; excessive oversight and step-by-step control; the prevalence of authoritative pedagogy); the specifics of the contingent of boarders (the presence of deprivation syndrome; difficulties in communicating with people who are around; the loss of empathy; the dominance of rent moods in relations with adults; the rivalry in relations with peers; the manifestation of contempt, rudeness, aggression towards younger and weaker girls and boys; inability and reluctance to work in a team, to do something for the sake of others).
\end{abstract}

Key words: a value attitude to a person, the formation of a value attitude to a person, teenagers, a comprehensive orphan boarding school, an after class activity.

Актуальність дослідження. Загострення політичних, економічних суперечностей призвели до зміни життєвих цінностей та ідеалів, що виявляється у прояві жорстокості та лицемірства у людських взаєминах. За таких обставин актуалізується необхідність формування у молодого покоління ціннісного ставлення до іншої людини.

Зазначена проблема є особливо актуальною для учнів шкіл-інтернатів, оскільки більшість 3 них - це педагогічно занедбані діти, для яких характерними $є$ схильність до нервових зривів, підвищена вразливість, наявність деприваційного синдрому, недовіра до дорослих, почуття самотності, зниження емпатії. 
Різні аспекти проблеми формування ціннісного ставлення до іншої людини знайшли відображення в працях психологів (I. Беха, І. Дубровіної, С. Максименка, В. Мухіної, В. М'ясищева, Д. Фельдштейна та інших); учених-педагогів (Ш. Амонашвілі, І. Білецької, І. Зязюна, Л. Канішевської, Г. Кирмач, О. Коберника, В. Сухомлинського, О. Сухомлинської, О. Третяк та інших). Водночас поза увагою дослідників залишилася складна та різноаспектна проблема формування ціннісного ставлення до іншої людини у підлітків шкіл-інтернатів.

Виклад основного матеріалу. Теоретичний аналіз філософської, психологічної, педагогічної літератури з проблеми дослідження дав змогу уточнити сутність понять «иіннісне ставлення до іншої людини», як інтегроване новоутворення, яке визначається гуманістичною етикою і мораллю та базується на таких моральних цінностях, як повага гідності, рівноправ'я, доброзичливість, виваженість, самодостатність, готовність до конструктивного діалогу та «формування цінності іншої людини» як спеціально організований виховний процес, який визначає ставлення до іншої людини як найвищої цінності, суб'єкта життя, спрямований на поєднання знань про такі моральні цінності, як повага гідності, рівноправ'я, доброзичливість, виваженість, самодостатність, готовність до конструктивного діалогу, уявлень про способи їх вияву та уміння керуватися ними у власній діяльності $[8 ; 9 ; 11 ; 12 ; 13 ; 14 ; 15 ; 16]$.

Аналіз наукових джерел із проблеми дослідження дозволив нам визначити особливості формування ціннісного ставлення до іншої людини у підлітків шкілінтернатів.

Підлітковий вік є сенситивним щодо формування ціннісного ставлення до іншої людини, оскільки типовими особливостями сучасного підлітка є такі: вибірковість в оцінці якостей іншої людини (фетишизація таких якостей, які найбільше імпонують підлітку); потреба в інтимно-особистісному спілкуванні зі значущими ровесниками [1, с. 82-83]; інтенсивний розвиток інтелектуальної, емоційної і вольової сфери; закладаються основи свідомої поведінки, окреслюється загальна спрямованість у формуванні моральних уявлень і соціальних настановлень [6; 7].

Однак, у підлітків спостерігаються викривлення у моральній сфері, хибні уявлення про моральні цінності та вияв ціннісного ставлення до іншої людини, які $є$ причиною аморальної поведінки чи негідних вчинків. «У зв’язку з недостатньо 
розвиненою вольовою сферою, такі підлітки не вміють стримувати себе, керувати емоціями, настроєм, контролювати поведінку, легко піддаються негативному впливові» [10, c. 225].

Досліджуваний нами контингент підлітків є вихованцями загальноосвітніх шкілінтернатів.

Вивчаючи проблеми виховної роботи в закладах інтернатного типу, дослідниця Л. Канішевська обгрунтовує головні завдання загальноосвітніх шкіл-інтернатів, а саме: забезпечення утримання та виховання дітей-сиріт і дітей, позбавлених батьківського піклування; забезпечення всебічного розвитку, фізичного, соціального та психічного здоров'я вихованців; створення умов, сприятливих для проживання дітей, їх навчання i виховання; засвоєння освітніх програм, навчання і виховання в інтересах особистості, суспільства і держави; забезпечення соціального захисту, медико-психологопедагогічної реабілітації та соціальної адаптації вихованців; забезпечення охорони і зміцнення здоров’я дітей; підготовка вихованців до майбутнього самостійного життя [2, с. 80-81]; «...створення умов, які б забезпечили вихованцям повноцінну участь у всіх сферах соціальних відносин; формування в учнів соціальних навичок; допомога вихованцям в особистісному та професійному самовизначенні» [3, с. 116].

Особливостями підготовки учнів шкіл-інтернатів до самостійного життя є: специфіка контингенту; соціальне сирітство, особливості організації життєдіяльності вихованців шкіл-інтернатів: заорганізованість життєдіяльності школярів, наслідками якої $є$ орієнтація поведінки вихованців на тотальний контроль 3 боку педагогів; відсутність індивідуального підходу до дитини, гіперопіка школярів; недостатні можливості щодо формування соціальної відповідальності учнів; обмеження соціального простору, наслідками якого є: вимушена адаптація до великої кількості однолітків, труднощі спілкування тощо; організаційно-педагогічні проблеми функціонування шкіл-інтернатів [5, с. 293-299]; недоліки освітнього процесу загальноосвітньої школи-інтернату, що заважають ефективному досягненню завдань виховання соціальної зрілості школярів; формальні вимоги для всіх учнів поза диференціацією їхніх здібностей та інтересів [4, с. 213-220]. 
Дослідження особливостей формування ціннісного ставлення до іншої людини у підлітків загальноосвітніх шкіл-інтернатів вимагає врахування двох груп чинників, які безпосередньо впливають на цей процес.

До першої групи чинників відносяться наступні: сенситивність підліткового віку щодо формування ціннісного ставлення до іншої людини (типовими особливостями сучасного підлітка є: вибірковість в оцінці якостей іншої людини; інтенсивний розвиток інтелектуальної, емоційної і вольової сфери; потреба в інтимно-особистісному спілкуванні зі значущими ровесниками; загальна спрямованість у формуванні моральних уявлень і соціальних настановлень; формування знань, уявлень щодо інших людей та стиль спілкування з ними); потенціал позаурочної діяльності загальноосвітніх шкілінтернатів у формуванні ціннісного ставлення до іншої людини (можливість проводити цілеспрямовану роботу з формування ціннісного ставлення до іншої людини; здійснення своєчасної діагностики рівнів сформованості ціннісного ставлення до іншої людини; тривале спілкування між вихованцями і педагогами, завдяки якому створюються можливості для гуманізації освітнього процесу, що вимагає сприяння формуванню гуманістичної спрямованості особистості, задоволенні потреб підлітків у вільному виборі видів діяльності; залучення учнів до гуманістично спрямованої діяльності, яка сприяє збагаченню досвіду моральної поведінки).

Друга група чинників, що значно ускладнює процес формування ціннісного ставлення до іншої людини у підлітків загальноосвітніх шкіл-інтернатів: соціальне сирітство; особливості організаційно-педагогічного функціонування загальноосвітніх шкіл-інтернатів (заорганізованість життєдіяльності вихованців; вимушена адаптація до великої кількості однолітків; зниження інтимності та довірливості у спілкуванні; надмірна опіка й покроковий контроль; превалювання авторитарної педагогіки); специфіка контингенту вихованців (наявність деприваційного синдрому; труднощі у спілкуванні з оточуючими; зниження емпатії; переважання рентних настроїв у стосунках з дорослими; суперництво у стосунках з ровесниками; вияв зневаги, грубості, агресії у ставленні до молодших і слабших; невміння і небажання працювати в колективі, робити щось заради інших).

Висновки. Отже, в даній статті визначено особливості формування ціннісного ставлення до іншої людини у підлітків загальноосвітніх шкіл-інтернатів, а саме: 
специфіка контингенту вихованців; сенситивність підліткового віку щодо формування ціннісного ставлення до іншої людини; використання потенціалу позаурочної діяльності; особливості організаційно-педагогічного функціонування шкіл-інтернатів.

Зазначимо, що аналіз проблеми формування ціннісного ставлення до іншої людини у підлітків шкіл-інтернатів потребує подальшого й різнопланового дослідження, зокрема, здійснення спеціальної підготовки педагогів шкіл-інтернатів із питань формування ціннісного ставлення до іншої людини.

\section{References}

1. Bulakh I. S. Psykholohia osobystisnoho zrostannia pidlitka : monohrafiia. [The psychology of a teenager's personal growth] Kyiv: NPU im. M. P. Drahomanova, 2003. 340p.

2. Kanishevs`ka L. V. Vy`xovannya social`noyi zrilosti starshoklasny`kiv zagal noosvitnix shkil-internativ u pozaurochnij diyal'nosti : [monography] [Educating social maturity in students of high school-orphanages in after class activity] Kyiv: KhmZNz, 2011. $368 \mathrm{p}$.

3. Kanishevs`ka L. V. Orhanizatsiia sotsialno-kulturnoi diialnosti starshoklasnykiv z formuvannia sotsialnoho dosvidu. [The organisation of social and cultural activities for senior students in order to form their social experience] Teoretyko-metodychni problemy vykhovannia ditei ta uchnivskoi molodi: zb. nauk. prats. Kirovohrad : TOV "Imeks-LTD", 2010. Issue 14. Book 1. P. 116-124.

4. Kanishevs`ka L. V. Doslidzhennia problemy vykhovannia sotsialnoi zrilosti starshoklasnykiv shkil-internativ. [The research of the problem of fostering social maturity in senior students of orphan boarding schools] Pedahohichnyi almanakh : zb. nauk. prats. Kherson KVNZ "Khersonska akademiia neperervnoi osvity", 2012. Issue 16. P. 213-220.

5. Kanishevska L. V. Doslidzhennia problemy pidhotovky starshoklasnykiv shkilinternativ do samostiinoho zhyttia. [The research of the problem of preparing senior students of orphan boarding schools to their own life] Teoretyko-metodychni problemy vykhovannia ditei ta uchnivskoi molodi: zb. nauk. prats. Kirovohrad: Imeks - LTD, 2013. Issue 17. Book 1. P. 293-299.

6. Kon I. S. Psıhologııa ranneı ıýnostı: [The psychology of early youth.] [knıga dlıa ýchitelia] Moskva: Prosvezhenie, 1989. 254, [1] p.

7. Pet'ko L. V. Stymuliuvannia tvorchykh zdibnostei pidlitkiv zasobamy vtilennia obrazu kazkovoho personazhu [Stimulating of teens'creativity abilities in view of embodiment the image fairy-tale character's]. Lialka yak znak, obraz, funktsiia: Mater. vseukr. nauk.-prakt. konf. "Druhi Marka Hrushevskoho chytannia" / za red. O.S.Naidena. - Kyiv : VD "Stylos", 2010. - P. 200-204.

8. Pet`ko L.V. Tury`zm-sprava zaxoplyuyucha [Tourism is a fascinating matter]. Rad. shkola. - 1990. - No 11. - P. 25-29. 
9. Pet'ko L.V., Verezij V.F. Pidlitok u riznovikovomu zagoni [Teenager in different age group]. Kyiv: Rad. shkola. 1989. No. 11. P. 6-12.

10. Savchyn M. V., Vasylenko, L. P. Vikova psykholohiia: navchalnyi posibnyk. [Age psychology: a textbook] Kyiv: Akademvydav.. 2011.368 s.

11. Shkolna M. S. Retrospektyvnyi analiz problemy vykhovannia sotsialnoi zrilosti molodi [Retrospective analysis of problem in upbringing of young people's social maturity]. Naukovyi visnyk Natsionalnoho un-tu bioresursiv i pryrodokorystuvannia Ukrainy. Seriia «Pedahohika. Psykholohiia. Filosofiia». Kyiv: Milenium, 2017. Issue. 259. P. 294-298.

12. Dmytrenko Christina, Pet'ko Lyudmila. Culture Values and Modern Society. «Bydeshteto vprosi ot sveta na naukata - 2013»: Tr. za 9 Mezhdunar.nauchna praktichna konf., 17-25 dekemvri 2013 ; red. Milko Todorov Petko. Vol. 28. PsihologiJa i sociologiJa, 2013. Sofija : «BjalGRAD-BG» OOD. P. 68-69.

13. Kanishevska Liubov. The formation of the immunity to the use of psychoactive substances in senior teenagers as the tendency of the formation of life safety // Topical issues of education: Collective monograph. - Pegasus Publishing, Lisbon, Portugal, 2018. P. 232-250.

14. Kanishevska L. V., Stadnik N. V. Theoretical aspects of the concept «responsibility» in works by foreign researchers. Perspectives of research and development: Collection of scientific articles. SAUL Publishing Ltd, Dublin, Ireland, 2017. P. 129-131.

15. Pet'ko Lyudmila. The "Case Study" Method as Means of Formation of a Professionally Oriented Foreign Language Teaching Environment in University Conditions. Intellectual Archive. - 2015. - Volume 4. - No. 4 (July). Series "Education \& Pedagogy". Toronto: Shiny Word Corp. - PP. 48-65. URI http://enpuir.npu.edu.ua/handle/123456789/7974

16. Ternopilska V. I. The role of self-government in development of leadership qualities among students // Problems of development modern science: theory and practice: Collection of scientific articles. - EDEX, Madrid, España, 2016. - P. 327-330.

17. Shkolna Maria. Pedagogical conditions for upbringing social maturity of students' agricultural colleges. Intellectual Archive. Toronto: Shiny Word.Corp. (Canada). 2017. September/October. Vol. 6. No. 5. PP. 79-85.

Translation of the Title, Abstract and References to the Author's Language

УДК: 37.018.32 - 057. 87:17.022.1:316.454-043.83

\section{Філоненко Леся. Особливості формування ціннісного ставлення до іншої людини у підлітків шкіл-інтернатів.}

У статті теоретично обгрунтовано особливості формування ціннісного ставлення до іншої людини у підлітків шкіл-інтернатів, а саме: специфіка контингенту вихованців (наявність деприваційного синдрому; труднощі у спілкуванні з оточуючими; зниження емпатії; переважання рентних настроїв у стосунках 3 дорослими; суперництво у стосунках з ровесниками; вияв зневаги, грубості, агресії у ставленні до молодших і слабших; невміння і небажання працювати в колективі, робити щось заради інших); 
сенситивність підліткового віку щодо формування ціннісного ставлення до іншої людини; використання потенціалу позаурочної діяльності; особливості організаційнопедагогічного функціонування шкіл-інтернатів.

Ключові слова: ціннісне ставлення до іншої людини, формування ціннісного ставлення до іншої людини, підлітки, загальноосвітня школа-інтернат, позаурочна діяльність.

\section{Филоненко Леся. Особенности формирования ценностного отношения к другому человеку у подростков школ-интернатов. \\ В статье теоретически обоснованы особенности формирования ценностного} отношения к другому человеку у подростков школ-интернатов, а именно: специфика контингета воспитанников (наличие депривационного синдрома; трудности в общении с окружающими; снижение эмпатии; преобладание рентных настроений в отношениях со взрослыми; соперничество в отношениях со сверстниками; проявление пренебрежения, грубости, агрессии в отношении к младшим и слабым; неумение и нежелание работать в коллективе, делать что-то ради других); сензитивность подросткового возраста по отношению к формированию ценностного отношения к другому человеку; использование потенциала внеаурочной деятельности; особенности организационно-педагогического функционирования школ-интернатов.

Ключевые слова: ценностное отношение к другому человеку, формирование ценностного отношения к другому человеку, подростки, общеобразовательная школаинтернат, внеурочная деятельность.

\section{Література}

1. Булах І. С. Психологія особистісного зростання підлітка : монографія. Київ: НПУ ім. М. П. Драгоманова, 2003. 340 с.

2. Канішевська Л. В. Виховання соціальної зрілості старшокласників загальноосвітніх шкіл-інтернатів у позаурочній діяльності: монографія. Київ: ХмЦНЦ, 2011. $368 \mathrm{c}$.

3. Канішевська Л. В. Організація соціально-культурної діяльності старшокласників $з$ формування соціального досвіду. Теоретико-методичні проблеми виховання дітей та учнівської молоді: зб. наук. праць. Кіровоград: ТОВ «Імекс-ЛТД, 2010. Вип. 14. Кн. 1. С. 116-124.

4. Канішевська Л.В.Дослідження проблеми виховання соціальної зрілості старшокласників шкіл-інтернатів. Педагогічний альманах: зб. наук. праць. Херсон КВНЗ «Херсонська академія неперервної освіти», 2012. Вип. 16. С. 213-220.

5. Канішевська Л. В. Дослідження проблеми підготовки старшокласників шкілінтернатів до самостійного життя. Теоретико-методичні проблеми виховання дітей та учнівської молоді: зб. наук. праць. Кіровоград: Імекс - ЛТД, 2013. Вип. 17, Кн. 1. С. $293-$ 299.

6. Кон И. С. Психология ранней юности: [книга для учителя] М.: Просвещение, 1989. 254, [1] c.

7. Петько Л. В. Стимулювання творчих здібностей підлітків засобами втілення образу казкового персонажу // Лялька як знак, образ, функція: М-ли Всеукр. наук.-практконф. «Другі Марка Грушевського читання» / за ред.. О.С Найдена. - К.: ВД. Стилос», 2010. - C. 200-204. URL http://enpuir.npu.edu.ua/handle/123456789/7887 
8. Петько Л. В. Туризм - справа захоплююча. Рад. школа. - 1990. - № 11. - С. 25 29. URL http://enpuir.npu.edu.ua/handle/123456789/7866

9. Петько Л.В., Верезій В.Ф. Підліток у різновіковому загоні. Радянська школа. Київ 1989. № 11. С. 6-12. URI http://enpuir.npu.edu.ua/handle/123456789/7865

10. Савчин М. В., Василенко Л. П. Вікова психологія: навчальний посібник. Київ: Академвидав.. 2011. $368 \mathrm{c}$.

11. Школьна М. С. Ретроспективний аналіз проблеми виховання соціальної зрілості молоді. Науковий вісник Національного ун-ту біоресурсів $i$ природокористування України. Серія «Педагогіка. Психологія. Філософія». - К.: Міленіум, 2017. - Вип. 259. - С. 294-298.

12. Dmytrenko Christina, Pet'ko Lyudmila. Culture Values and Modern Society. «Бъдещето въпроси от света на науката - 2013»: Тр. за 9 Междунар.научна практична конф., 17-25 декември 2013 ; ред. Милко Тодоров Петко. - Т. 28. Психология и социология, 2013. - София : «БялГРАД-БГ» ООД. - С. 68-69. URI http://enpuir.npu.edu.ua/handle/123456789/10531

13. Kanishevska Liubov. The formation of the immunity to the use of psychoactive substances in senior teenagers as the tendency of the formation of life safety // Topical issues of education: Collective monograph. - Pegasus Publishing, Lisbon, Portugal, 2018. P. 232-250.

14. Kanishevska L. V., Stadnik N. V. Theoretical aspects of the concept «responsibility» in works by foreign researchers. Perspectives of research and development: Collection of scientific articles. SAUL Publishing Ltd, Dublin, Ireland, 2017. P. 129-131.

15. Pet'ko Lyudmila. The "Case Study" Method as Means of Formation of a Professionally Oriented Foreign Language Teaching Environment in University Conditions [Метод ситуаційного аналізу («case study» method) як засіб формування професійно орієнтованого іншомовного навчального середовища в умовах університету]. Intellectual Archive. - 2015. - Volume 4. - No. 4 (July). Series "Education \& Pedagogy". - Toronto : Shiny Word Corp. - PP. 48-65. URI http://enpuir.npu.edu.ua/handle/123456789/7974

16. Ternopilska V. I. The role of self-government in development of leadership qualities among students // Problems of development modern science: theory and practice: Collection of scientific articles. - EDEX, Madrid, España, 2016. - P. 327-330.

17. Shkolna Maria. Pedagogical conditions for upbringing social maturity of students' agricultural colleges. Intellectual Archive. Toronto: Shiny Word.Corp. (Canada). 2017. September/October. Vol. 6. No. 5. PP. 79-85. 


\title{
A Competency Approach as a Methodological Basis in the Formation of Performing Skills in Future Music Teachers and Musicians From China
}

\author{
Lu Tao \\ ORCID https://orcid.org/0000-0002-0008-5134 \\ Postgraduate student \\ Dragomanov National Pedagogical University (Ukraine, Kyiv)
}

\begin{abstract}
The article is devoted to the study of the content of the competence approach. The key concepts of competency approach: competence, competence, competence, as well as competence in the musical-performing field, competence of the music teacher, professional music competence, musical-performing competence of the future teacher of music are analyzed and presented. The relevance and expediency of the use of a competent approach in the formation of performing skills of future music teachers of China is substantiated. It is revealed that the application of a competent approach in the formation of the performing arts of future music teachers of China allows: to establish and develop interrelationships between personality, education and profession; to select the content of vocational education, respectively, to the needs of the developing person, and to the actual professional requirements due to the peculiarities of modern music and pedagogical practice; direct the formation of executive competence for the perfect possession of the instrument in order to ensure the maximum artistic influence on the development of the child's personality and the implementation of many other pedagogical tasks.
\end{abstract}

Key words: future teacher-musician, China, competency approach, competence, performing skills.

Актуальність дослідження. Процеси глобалізації та інтеграції є найхарактернішою особливістю розвитку сучасного світу. Ці процеси притаманні усім без винятку сферам людського життя. В освіті вони виявляються у розробці та впровадженні нових методологічних підходів: таких, що відповідають мінливим вимогам сьогодення та орієнтовані не лише на становлення особистості, а й на формування конкретних уніфікованих здатностей до здійснення певної професійної діяльності, що забезпечують затребуваність фахівця на ринку праці у будь-якій країні. Підходом, що дозволяє ефективно вирішувати вищевикладені завдання на всіх рівнях освіти та у всіх її галузях (зокрема, мистецькій), сформувати виконавську майстерність майбутніх педагогів-музикантів Китаю в педагогічних університетах України таким чином, що вони зможуть успішно застосовувати іiі у розв'язанні фахових завдань як у себе на батьківщині, так і у всьому світі - $є$ компетентнісний. Це і буде метою даної статті.

Виклад основного матеріалу. Компетентнісний підхід є методологічною 
основою сучасної освіти та одним із напрямів педагогічних досліджень вищої школи. Завдяки компетентнісному підходу, стверджує Л. Теряєва, людина формується як особистість, фахівець і громадянин [14].

Проблеми реалізації компетентнісного підходу на різних щаблях освітнього процесу вивчали Л. Антонюк, Ю. Багно, Є. Зеєр, О. Кулик, Л. Овсієнко, Дж.Равен, Г. Селевко, Ю. Татур, Л. Теряєва, А. Хуторський, О. Шахматова та ін. Питання функціонування компетентнісного підходу в галузі мистецької освіти, зокрема, у підготовці майбутніх учителів музики досліджували С. Булгакова, С. Грозан, А. Казурова, Ю. Калиніна, С. Світайло, О. Щолокова, В. Яковлєв та ін.

Компетентнісний підхід (КП) в освіті розглядається науковцями як сукупність загальних принципів визначення цілей освіти, вибору змісту освіти, організації освітнього процесу, оцінки результатів освіти. КП передбачає пріоритетну орієнтацію на цілі освіти: якість освіти, здатність до навчання, самовизначення, самоактуалізацію, самореалізацію, соціалізацію і розвиток індивідуальності учня. Метою реалізації КП в професійній освіті є формування компетентного фахівця, що володіє всіма необхідними компетентностями у професійній діяльності.

Перехід до компетентнісного підходу означає переорієнтацію 3 процесу на результат освіти в діяльнісному вимірюванні, у зміщенні акценту з накопичування нормативно визначених знань, умінь і навичок на формування й розвиток в учнів здатності практично діяти, застосовувати досвід успішних дій у конкретних ситуаціях, на організацію освітнього процесу на основі тверезого урахування затребуваності навчальних досягнень випускника школи в суспільстві, забезпечення його спроможності відповідати реальним запитам швидко змінюваного ринку й мати сформований потенціал для швидкої безболісної адаптації як у майбутній професії, так і в соціальній структурі [4].

С. Булгакова відзначає, що застосування КП у підготовці майбутніх працівників системи музичного виховання і освіти диктує свої особливі вимоги як до структури, рівня й змісту навчального процесу, так і до особистості вчителя музики [2]. Зокрема, як стверджує С. Грозан, компетентнісний підхід в мистецькій освіті передбачає формування у студентів вищих навчальних закладів музичних компетенцій, тобто необхідного комплексу знань, навичок, відносин та досвіду, що допоможе реалізувати 
професійну підготовку майбутніх учителів, сформувати у них готовність до самореалізації у музично-освітній діяльності [3]. С. Світайло зазначає, що сучасна компетентнісна концепція спрямована на удосконалення підготовки майбутніх педагогів-музикантів шляхом формування у них фахової компетентності як складової професіоналізму, яка охоплює особистісні характеристики, теоретичні знання, практичні здатності у сфері професійної діяльності [11].

Методологічною підставою реалізації компетентнісного підходу в професійній освіті виступають принципи: варіативності освіти; спрямованості освіти на розвиток і саморозвиток особистості; поєднання автономності 3 колективними та груповими формами освіти; нестійкої динамічної рівноваги освітнього процесу як джерела розвитку взаємозв'язків особистості, освіти та професії; співрозвитку особистості, освіти та діяльності [6].

Отже, «компетентнісний підхід» розглядають як методологічну основу оновлення змісту, цілей, якості вищої освіти [14] та розуміють як спрямованість освітнього процесу на формування й розвиток ключових (базових, основних, надпредметних) і предметних компетентностей особистості $[4 ; 12 ; 13 ; 15 ; 17]$.

Слід відзначити, що на сьогоднішній день не існує усталених визначень ключових понять компетентнісного підходу: вони все ще залишаються предметом обговорень та дискусій. Так, у сучасних психолого-педагогічних дослідженнях поняття «компетенція» тлумачать як сукупність професійних знань, умінь, способів виконання професійної діяльності (Є. Зеєр, О. Шахматова [5]); «компетентність» - як специфічну здатність, що необхідна для ефективного виконання конкретної дії у конкретній предметній галузі та включає вузькоспеціальні знання, особливого роду предметні навички, способи мислення, а також розуміння відповідальності за свої дії (Дж.Равен [10]). Поняття «компетенщія у музично-виконавській сфері» розуміють як здатність до успішного вирішення професійних завдань у виконавській, науковій, творчій, педагогічній галузях діяльності на основі набутих знань, умінь і навичок [7]. «Професійну компетентність педагога» трактують як єдність теоретичної і практичної підготовленості до здійснення педагогічної діяльності, що характеризує його професіоналізм [1].

Дослідники професійної компетентності учителя музики відзначають, що вона 
має свою специфіку, визначається метою і змістом музично-освітньої діяльності в школі. Компетентність учителя музики розуміється як: особистісна якість, яка виявляється суто у професійній діяльності (С. Булгакова [2]); особистісне утворення, складне, динамічне за своєю структурою, яке можна модифікувати відповідно до змісту і рівня освіти (С. Світайло [11]); якість реалізації на практиці результату формування в суб'єктів навчання фахових музичних компетенцій, визначення яких $\epsilon$ важливою методологічною позицією для аналізу цього феномену i керування процесом його формування (С. Грозан [3]).

С. Булгакова стверджує, що у новій освітній парадигмі навчальні дисципліни немов би «випливають» із компетенцій. По суті, компетенції є професіограмою, в якій відображена повна кваліфікаційна характеристика вчителя музики з позицій вимог, що пред'являються не тільки до його знань, умінь, володіння, а й до його особистості, здібностей, психофізіологічних можливостей [2].

Професійну компетентність учителя музики поряд 3 багатьма іншими компетенціями складають фахові музичні компетенції. Вони зумовлюють успішну самореалізацію майбутнього вчителя у музично-освітній діяльності та здійснення музично-педагогічного впливу. С. Грозан розуміє фахові музичні компетенції як сукупність базових музичних знань, сформованих умінь і навичок елементарного музикування (виконавства), оцінної діяльності та досвіду творчої музичної діяльності [3].

На думку В. Яковлєва, яку поділяємо і ми, ядром професійної компетентності вчителя музики загальноосвітньої школи $є$ його музично-виконавська компетентність. Науковець визначає музично-виконавську компетентність майбутнього вчителя музики як інтегративне утворення особистості, що має системну організацію, складну багаторівневу структуру і виступає як сукупність, взаємодія особистісного, когнітивнодіяльнісного і рефлексивного компонентів, ступінь сформованості яких дозволяє вчителеві музики ефективно здійснювати музично-виконавську діяльність. В. Яковлєв наголошує, що музично-виконавська компетентність дає можливість майбутньому вчителю музики усвідомити себе суб'єктом музично-виконавської діяльності та дозволяє удосконалюватися у професійному й особистісному плані [16].

Висновки. Отже, питанням компетентнісного підходу присвячені праці 
багатьох вчених. КП вважається науковцями провідним методологічним орієнтиром у модернізації сучасної освіти, суть якого полягає у формуванні та розвитку в учнів компетентностей, що забезпечують успішну професійну діяльність. Компетентності педагога-музиканта складаються з компетенцій, які, з одного боку, є наперед заданими освітніми вимогами, в яких відображена кваліфікаційна характеристика учителя музики, а з іншого - сукупністю набутих, розвинутих, сформованих та інтегрованих в процесі музичного навчання здібностей, знань, умінь, навичок та якостей, що дозволяють здійснювати успішну музично-педагогічну діяльність.

Професійна компетентність учителя музики визначається метою та змістом музично-освітньої діяльності у школі. Вона є інтегральною особистісною якістю, що утворюється у результаті набуття музичного, педагогічного й життєвого досвіду та забезпечує професійну самореалізацію педагога-музиканта на відповідному рівні. Музично-виконавська компетентність розглядається вченими як ядро професійної компетентності учителя музики загальноосвітньої школи; як інтегративне утворення особистості, що має системну організацію та складну багаторівневу структуру. Виконавська майстерність передбачає високий рівень виконавської компетентності. Відтак, застосування компетентнісного підходу у формуванні виконавської майстерності майбутніх педагогів-музикантів Китаю дозволяє: встановити та розвинути взаємозв'язки особистості, освіти та професії; здійснити відбір змісту професійної освіти відповідно як до потреб особистості, що розвивається, так і до актуальних професійних вимог, зумовлених особливостями сучасної музично-педагогічної практики; спрямувати формування виконавської компетентності на досконале володіння інструментом задля забезпечення максимального художнього впливу на становлення особистості дитини та реалізації багатьох інших педагогічних завдань.

\section{References}

1. Bagno Yu.N., Sergeychuk E.N. Kompetentnostnyiy podhod v sisteme prakticheskoy podgotovki buduschih uchiteley [Competence approach in the system of practical training of future teachers]. Nauchno-metodicheskiy elektronnyiy zhurnal «Kontsept». 2014. No 09 (sentyabr). P. 141-145. ART 14255. 0,4 p. 1. URL: http://e-koncept.ru/2014/14255.htm.

2. Bulgakova S.N. Tendentsii vyisshego professionalnogo muzyikalnopedagogicheskogo obrazovaniya: kompetentnostnyiy podhod [Tendencies of higher professional musical and pedagogical education: competence approach]. Vestnik Chelyabinskoy gos. akademii kulturyi i iskusstv. 2009. No 3 (19). P. 120-123. 
3. Grozan S. Kompetentnisniy pidhid yak skladova chastina pidgotovki maybutnogo vchitelya muziki do profesiynoyi samorealizatsiyi [Competency approach as an integral part of preparing the future teacher of music for professional self-realization]. Naukovi zapiski Kirovogradskogo derzh. ped. universitetu imeni V.Vinnichenka. Seriya: Pedagogichni nauky. 2014. Vol. 132. P. 282-285.

4. Zagalni ponyattya pro kompetentnisniy (diyalnisniy) pidhid $v$ osviti. NaukovometodichnI zasadi vprovadzhennya derzhavnogo standartu pochatkovoyi zagalnoyi osviti [General concepts of competency (activity) approach in education. Scientific and methodological principles of implementation of the state standard of elementary general education] // Proektuvannya ta provedennya uroku $\mathrm{v}$ pochatkovih klasah na zasadah kompetentnisnogo (diyalnisnogo) pidhodu: navchalne vidannya / B-ka zhurn. «Pochatkove navchannya ta vihovannya» ; uporyad. Drozhzhina T.V., Gezey O.M. H.: Vid. gruppa «Osnova», 2014. Vol. 8 (128). 127, [1] p.

5. Zeer E.F., Shahmatova O.N. Lichnostno orientirovannyie tehnologii professionalnogo razvitiya spetsialista: nauch.-metod. posobie [Personally oriented technologies of professional development of a specialist: scientific-method. allowance]. Ekaterinburg: Izd-vo UGPPU, 1999. 245 p.

6. Ibragimova L.A., Petrova G.A., Trofimenko M.P. Kompetentnostnyiy podhod metodologicheskaya osnova sovremennogo obrazovaniya [Competence approach - the methodological basis of modern education]. Vestnik Nizhnevartovskogo gos. un-ta. 2010. No 1. P. 57-66.

7. Kazurova A.S. Problemyi gosudarstvennogo obrazovatelnogo standarta vyisshego professionalnogo muzyikalnogo obrazovaniya: opyit i perspektivyi [Problems of the State Educational Standard of Higher Professional Music Education: Experience and Prospects]. Moskva: Issledovatelskiy tsentr problem kachestva podgotovki spetsialistov, 2005. 93 p.

8. Pet'ko L.V. Vyhovnyj $i$ profesijnyj aspekty muzychno-pedagogichnoi' sprjamovanosti navchannja inozemnoi' movy studentiv VNZ u systemi muzychnopedagogichnoi' osvity [Educational and professional aspects of music-pedagogical orientation of foreign language teaching for students in the system of music-pedagogical training] / Muzyka ta osvita : naukovo-metod.zhurnal / zasn. MON Ukrai'ny, NAPN Ukrai'ny, Kyi'vs'ka dytjacha akademija mystectv ; gol.red. L.M.Masol. Kyi'v : Pedagogichna dumka, 2013. № 3. C. 14-18.

9. Pet'ko L.V. Robota nad pisneju v kursi anglijs'koi' movy jak odyn iz zasobiv profesijnoi' pidgotovky studentiv gumanitarnyh special'nostej VNZ [The song in English course as a means of training humanities majors university students']. Inozemni movy. 2011. No 1. P. 44-48.

10. Raven Dzh. Pedagogicheskoe testirovanie: problemyi, zabluzhdeniya, perspektivyi: per. s angl. [Pedagogical testing: problems, misconceptions, perspectives]. Moskva: Kogito-Tsentr, 1999. 144 p.

11. Svitaylo S.V. Kompetentnisna pidgotovka vikladacha muzichnogo mistetstva [Competent training of the teacher of musical art] // Profesiyna mistetska osvita i hudozhnya kultura: vyklyki XXI stolittya : zb. mat. Mizhn. nauk.-prakt. konf. (Kiyiv, 16-17.10.2014). Kyiv: Kiyivskiy un-t im. B.Grinchenka, 2014. P. 670-675. 
12. Ternopilska V.I. Struktura profesiinoi kompetentnosti maibutnoho fakhivtsia [The structure of professional competence of a future specialist]. Naukovyi visnyk Melitopolskoho derzh. pedahohichnoho universytetu. Seriia: Pedahohika. 2012. Vol. 9. P. 208-213.

13. Ternopilska V.I. Modeliuvannia samoosvitnoi kompetentnosti maibutnikh fakhivtsiv [Modeling of self-education competence of future specialists]. Pedahohichna osvita: teoriia i praktyka. Psykholohiia. Pedahohika. 2016. Vol. 25. P. 6-22.

14. Teryaeva L.A. Formuvannya metodichnoyi kompetentnosti maybutnIh vchiteliv muziki: kategorialniy analiz problemy [Formation of methodical competence of future music teachers: categorical analysis of the problem] / Profesiyna mistetska osvita i hudozhnya kultura: vyklyki XXI stolittya : zb. mat. Mizhn. nauk.-prakt. konf. (Kiyiv, 16-17.10.2014). Kyiv: Kiyivskiy un-t im. B.Grinchenka, 2014. P. 675-682.

15. Shcholokova O.P. Novitni pidkhody ta tekhnolohii u profesiinii pidhotovtsi vchytelia mystetskykh dystsyplin [New approaches and technologies in professional art teachers training] // Innovative processes in education: Collective monograph. - AMEET Sp. z o.o., Lodz, Poland, 2017. P. 238-246.

16. Yakovlev V.S. Teoreticheskaya model formirovaniya muzyikalno-ispolnitelskoy kompetentnosti buduschogo uchitelya muzyiki [Theoretical model of the formation of musical and performing competence of the future music teacher]. Uchenyie zapiski. Elektronnyiy nauchnyiy zhurnal Kurskogo gosudarstvennogo universiteta. 2010. No 2 (14). P. 210-216.

17. Pet'ko Lyudmila. Preparing higher school graduates in foreshortening of leader competencies for 2020. Topical questions of contemporary science: Collection of scientific articles. Aspekt Publishing of Budget Printing Center, Taunton, MA 02780, United States of America, 2017. P. 467-472.

Translation of the Title, Abstract and References to the Author's Language

\section{УДК 278.011.3-051-047.22:78}

Лу Тао. Компетентнісний підхід як методологічна основа у формуванні виконавської майстерності майбутніх педагогів-музикантів Китаю.

Статтю присвячено вивченню змістовної сутності компетентнісного підходу. Проаналізовано та представлено розуміння науковцями ключових понять КП: компетенція, компетенції, компетентність. З'ясовано, що застосування компетентнісного підходу у формуванні виконавської майстерності майбутніх педагогів-музикантів Китаю дозволяє: встановити та розвинути взаємозв'язки особистості, освіти та професії; здійснити відбір змісту професійної освіти відповідно як до потреб особистості, що розвивається, так і до актуальних професійних вимог, зумовлених особливостями сучасної музично-педагогічної практики; спрямувати формування виконавської компетентності на досконале володіння інструментом задля забезпечення максимального художнього впливу на становлення особистості дитини та реалізації багатьох інших педагогічних завдань.

Ключові слова: компетентнісний підхід, компетенція, компетенції, компетентність, виконавська майстерність, майбутні педагоги-музиканти Китаю. 


\section{Лу Тао. Компетентностный подход как методологическая основа в формировании исполнительского мастерства будущих педагогов-музыкантов}

Китая.

Статья посвящена изучению содержательной сущности компетентностного подхода. Проанализировано и представлено понимание учеными ключевых понятий компетентностного подхода: компетенция, компетенции, компетентность. Установлено, что применение компетентностного подхода в формировании исполнительского мастерства будущих педагогов-музыкантов Китая позволяет: установить и развить взаимосвязи личности, образования и профессии; осуществить отбор содержания профессионального образования в соответствии как с потребностями развивающейся личности, так и с актуальными профессиональными требованиями, обусловленными особенностями современной музыкально-педагогической практики; направить формирование исполнительской компетентности на совершенное владение инструментом для обеспечения максимального художественного влияния на становление личности ребенка и реализации многих других педагогических задач.

Ключевье слова: компетентностный подход, компетенция, компетенции, компетентность, исполнительское мастерство, будущие педагоги-музыканты Китая.

\section{Література}

1. Багно Ю.Н., Сергейчук Е.Н. Компетентностный подход в системе практической подготовки будущих учителей. Научно-метод. электронный журнал «Концепт». 2014. № 09 (сентябрь). С. 141-145. ART 14255. 0,4 п. л. URL: http://ekoncept.ru/2014/14255.htm.

2. Булгакова С.Н. Тенденции высшего профессионального музыкальнопедагогического образования: компетентностный подход. Вестник Челябинской государственной академии культуры и искусств. 2009. №3 (19). С. 120-123.

3. Грозан С. Компетентнісний підхід як складова частина підготовки майбутнього вчителя музики до професійної самореалізації. Наукові записки Кіровоградського державного педагогічного університету імені В.Винниченка. Серія: Педагогічні науки. 2014. Вип. 132. С. 282-285.

4. Загальні поняття про компетентнісний (діяльнісний) підхід в освіті. Науковометодичні засади впровадження державного стандарту початкової загальної освіти // Проектування та проведення уроку в початкових класах на засадах компетентнісного (діяльнісного) підходу: навч. видання / Б-ка журн. «Початкове навчання та виховання» / упоряд. Дрожжина Т.В., Гезей О.М. Харків: Вид. группа «Основа», 2014. Вип. 8 (128). 127, [1]c.

5. Зеер Э.Ф., Шахматова О.Н. Личностно ориентированные технологии профессионального развития специалиста: науч.-метод. пособие. Екатеринбург: Изд-во УГППУ, 1999. 245 с.

6. Ибрагимова Л.А., Петрова Г.А., Трофименко М.П. Компетентностный подход методологическая основа современного образования. Вестник Нижневартовского государственного ун-та. 2010. № 1. С. 57-66.

7. Казурова А.С. Проблемы государственного образовательного стандарта 
высшего профессионального музыкального образования: опыт и перспективы. Москва: Исследовательский центр проблем качества подготовки специалистов, 2005. 93 с.

8. Петько Л.В. Виховний i професійний аспекти музично-педагогічної спрямованості навчання іноземної мови студентів ВНЗ у системі музично-педагогічної освіти. Музика та освіта : науково-метод.журнал / засн. МОН України, НАПН України, Київська дитяча академія мистецтв ; гол.ред. Л.М.Масол. Київ : Педагогічна думка, 2013. № 3. С. 14-18.

9. Петько Л.В. Робота над піснею в курсі англійської мови як один із засобів професійної підготовки студентів гуманітарних спеціальностей ВНЗ. Іноземні мови : наук.-метод. журн. / засн. Київський лінгвістичний ун-т і вид-во «Ленвіт» ; гол. ред. С.Ю.Ніколаєва. К. : Вид-во «Ленвіт», 2011. № 1 С. 44-48.

10. Равен Дж. Педагогическое тестирование: проблемы, заблуждения, перспективы: пер. с англ. Москва: Когито-Центр, 1999. 144 с.

11. Світайло С.В. Компетентнісна підготовка викладача музичного мистецтва // Професійна мистецька освіта і художня культура: виклики ХХІ століття: мат. міжн. наук.-практ. конф. (м. Київ, 16-17.10.2014p.). Київ: Київський ун-т ім. Б.Грінченка, 2014. C. $670-675$.

12. Тернопільська B.I. Структура професійної компетентності майбутнього фахівця. Науковий вісник Мелітопольського держ. педагогічного університету. Серія: Педагогіка. 2012. Вип. 9. С. 208-213.

13. Тернопільська В.І. Моделювання самоосвітньої компетентності майбутніх фахівців. Педагогічна освіта: теорія і практика. Психологія. Педагогіка. 2016. Вип. 25. C. 6-22.

14. Терясва Л.А. Формування методичної компетентності майбутніх вчителів музики: категоріальний аналіз проблеми // Професійна мистецька освіта і художня культура: виклики XXI століття: мат. міжн. наук.-практ. конф. (м. Київ, 16-17.10.2014p.). Київ: Київський ун-т ім. Б.Грінченка, 2014. С. 675-682.

15. Щолокова О.П. Новітні підходи та технології у професійній підготовці вчителя мистецьких дисциплін / О.П.Щолокова // Innovative processes in education: Collective monograph. - AMEET Sp. z o.o., Lodz, Poland, 2017. - P. 238-246.

16. Яковлев B.C. Теоретическая модель формирования музыкальноисполнительской компетентности будущого учителя музыки // Ученые записки. Электронный научн. журнал Курского гос. Ун-та. 2010. №2 (14). С. 210-216.

17. Pet'ko Lyudmila. Preparing higher school graduates in foreshortening of leader competencies for 2020. Topical questions of contemporary science: Collection of scientific articles. Aspekt Publishing of Budget Printing Center, Taunton, MA 02780, United States of America, 2017. P. 467-472. 


\title{
The Forming Creative Skills in Future Art Teachers in Pedagogical Higher Education Establishments
}

\author{
Prihodin M. D. \\ ORCID https://orcid.org/0000-0002-6891-8585 \\ H.S. Skovoroda Kharkiv National Pedagogical University (Ukraine, Kharkiv)
}

\begin{abstract}
The article covers the process of forming creative skills in future teachers of artistic disciplines in higher pedagogical higher education establishments. At the same time, the cultural orientation of the educational process is emphasized, where the role of the teacher as a subject of the pedagogical process requires the improvement of the system of education and national values on the levels of European standards. Creative skills contribute to the vision of a new, unique, original; cause independent thinking, generating original ideas, content, image forms, creating a harmoniously holistic art piece. The study of artistic disciplines is a specific form of teaching the teacher of fine arts, which in a pedagogical activity is intended to directly form the creative skills of students. At the same time, modern educational realities need to integrate Ukraine into the European educational community. Defined creative abilities as basic, with which you can create a creative product in general, with the subsequent formation of creative skills in the context of the specification on various artistic disciplines (painting, graphics, sculpture, batik, fresco, ceramics and many others). Artistic and aesthetic directions of the phenomenon of "creative skills" are considered in terms of their content, style and forms of image with adequate skills of the student - the future teacher. The creative skills of the teacher combined with the existing optimal pedagogical conditions and pedagogy of teaching artistic educational disciplines, allow us to understand more deeply the dialectical nature of the interdependence between meaningful imagery and forms, image styles in the context of the use of poly-artistic functions of each creative skill during the production of a creative product, an artistic work.
\end{abstract} aesthetics.

Keywords: creativity, craftsmanship, artistic disciplines (visual arts, design), pedagogical culture,

Актуальність дослідження. Вища педагогічна школа відповідальна за розвиток творчого потенціалу нації й формування творчих умінь студентів та підготовки конкурентоспроможніх учителів, i, в тому числі, з художніх дисциплін. Учитель у своїй педагогічній діяльністі реалізує державну політику для створення творчого потенціалу нації, розвитку культури й творчих умінь, формування творчої особистості, серед яких творчі уміння є одними з провідних й визначальних. Творчі уміння сприяють баченню нового, неповторного, оригінального; обумовлюють самостійне мислення, генеруючи оригінальні ідеї, змістовність, форми зображення, створюючи гармонійно-цілісний художній твір. Вивчення художніх дисциплін $\epsilon$ специфічною формою навчання майбутнього вчителя образотворчого мистецтва, який у педагогічній діяльності покликаний безпосередньо формувати творчі уміння учнів. Водночас, сучасні реалії навчання потребують інтегрування України до європейського освітнього 
співтовариства, що обумовлює критичне осмислення й творче застосування в умовах нашої держави, передового зарубіжного досвіду. Через що досліджувана проблема $є$ актуальною й розглядається в аспекті методики формування творчих умінь майбутнього вчителя як творчої особистості нового типу, збагаченої власними творчими вміннями на рівні європейських і світових стандартів.

Аналіз наукових досліджень і публікацій. Художня творчість, творчі уміння в образотворчому мистецтві досліджувались у працях відомих науковців, художниківпедагогів (Є. Антонович, О. Григоренко, Л. Гриневич, В. Даниленко, В. Кремень, Н. Кузьміна， Л. Масол， С. Сисоєва， О. Сова， О. Щолокова， О. Шевнюк та ін.), де зазначається, що вже першокурсник вишу, отримуючи знання, проявляє розуміння в необхідності формування саме власних творчих умінь. Вирішувати творчі завдання зможе педагог, який сам володіє творчими вміннями оскільки «особистість виховує особистість» (К. Ушинський).

Мета статті - висвітлити методику формування творчих умінь майбутніх учителів художніх дисциплін і використання набутих знань, умінь, навичок у професійній педагогічній діяльності. А також визначити такі творчі вміння, які $\epsilon$ базовими для створення будь-якого творчого продукту, відповідно спеціалізації різних художніх дисциплін.

Виклад основного матеріалу дослідження. Методика формування творчих умінь майбутніх учителів образотворчого мистецтва здійснюється в обгрунтованій концепції - «деконструкція» застарілих методів, проведення аналізу та синтезу поліхудожніх функцій кожного творчого вміння, які збагачені художньо-образним змістом і формами зображення, віддзеркалюють їх функціональне призначення (майстерність, образність, цілісність).

На нашу думку, - ия формула аналітичного мистецзтва поєднана 3 художньою інтуїцією, інноваційними технологіями «хай-тек». Майбутній вчитель нового типу - це особистість із всебічно розвинутим інтелектом, яка збагачена власними творчими уміннями в контексті розбудови національної художньої освіти, націлений на відродження української ментальності [3]. 
Наголосимо, що художній твір відрізняється від технічного - реальним зображенням дійсності в художніх образах із психологічним настроєм $[6 ; 7 ; 8 ; 9 ; 10 ; 11$; 12], чого технічний проект не передбачає.

Н Кузьміна у творчому мисленні педагога, як творчої особистості, виділяє гострий розум, винахідливість, критичність і вважає однією 3 причин невдачі у педагогічній діяльності «рабське слідування обраному стандарту» [2, с. 83]. До того ж, у будь-якому творі — літературному, музичному і художньому має бути присутній композиційний задум і порядок побудови. Щось повинно бути головним, а інше другорядним, що підпорядковане головному. Якщо цього не буде, твір розпадеться на окремі, нічим не пов’язані самостійні частини. Тому, «...цілісності твору вже не існуватиме», — підкреслює професор В. Даниленко [1, с 151]. У національній доктрині розвитку освіти України обумовлено завдання щодо створення оптимальних педагогічних умов.

Перша педагогічна умова: формування творчих умінь — це наявність у студента нестандартного мислення, системи певних знань, навичок, а також розвиненої структури психологічних компонентів: інтуїції, уяви, фантазії.

Друга педагогічна умова — цілеспрямоване формування творчих умінь кожної особистості, здатності діяти в інтегральному культурологічному спрямуванні, спілкування мистецькою мовою, оперуючи їх художніми образами, що включає три основних компоненти: аналіз через синтез, нестандартне вирішення, рефлексія й оцінювання власних творчих умінь.

Третя педагогічна умова формування творчих умінь — національний менталітет з європейським світоглядом на цінності, творча особистість.

Оптимальні педагогічні умови формування творчих умінь вчителя - це організаційна форма навчально-виховного процесу за таких вимог:

• стійкий моральний та фізичний стан як викладача, так і студента;

• належне науково-методичне й матеріальне забезпечення;

- творча співпраця викладача зі студентами й студентів між собою;

- самостійна творча робота, самовдосконалення, самооцінка;

• проведення «майстер-класів», експериментів, наукових досліджень;

• участь у конкурсах, художніх виставках, міжнародних олімпіадах. 
Отже, створені оптимальні педагогічні умови забезпечують підготовку творчої особистості й конкурентоспроможного вчителя на ринку праці.

Разом з тим необхідно створювати плідний грунт для дистанційного навчання, самостійного творчого мислення, де викладач повинен творчо підходити до методичної допомоги кожному студенту, особливостям психічного й морального його стану та вирішення суперечностей.

А далі студентські роботи необхідно представляти на різних конкурсах, художніх виставках, як найбільш результативні в плані творчих умінь.

Наведемо висловлювання науковцями розуміння творчих умінь.

Для навчально-виховного процесу, а також виконання навчальних і творчих завдань студентами, визначним науковцем, педагогом С. Сисоєвою запропоновані такі творчі вміння: 1) проблемне бачення - уміння усвідомити і побачити проблему; 2) здатність до висування гіпотез, оригінальних ідей, за допомогою яких на підставі фактів робиться висновок про об'єкти, явища, їх розвиток; 3) уміння аналізувати, інтегрувати та синтезувати інформацію - вміння розділяти ціле на частини, поєднувати частини в єдине ціле, знаходити логічні взаємозв'язки між окремими частинами цілого; 4) здатність до виявлення протиріч - здатність бачити діалектичне протиріччя; 5) здатність до дослідницької діяльності; 6) розвинуте уявлення, фантазія; 7) здатність до міжособистісного спілкування; 8) уміння довести почату справу до кінця; 9) уміння встановлювати причинно-наслідкові зв'язки, приховані взаємодії [4, с. 73-74].

Дослідження, проведене I. Баришніковою, дозволило виявити особливості специфіки формування творчих умінь, сприймання й розуміння архітектури:

1) уміння правильно оцінювати співвідношення частин і цілого; 2) уміння уявно оперувати образом у просторі; 3) уміння правильно оцінювати та передавати в малюнку або макеті обсяг і положення будинку в просторі.

Тож, проводячи наукові дослідження методики формування творчих умінь майбутнього вчителя образотворчого мистецтва в процесі навчання художніх дисциплін, нами сформовані власні базові творчі вміння із урахуванням змістовнообразних поліхудожніх функцій для виконання навчальних завдань й творчого продукту, а також завдяки яким, здійснюється професійно-педагогічна діяльність: 
1. Уміння визначати головне й другорядне, опановуючи художню майстерність, відображаючи дійсність у художніх виразних образах.

2. Уміння проводити аналіз і синтез, відтворюючи характери, емоції персонажів або стан природи в контексті гармонійної цілісності твору.

3. Уміння пропонувати гіпотези, нестандартні оригінальні ідеї, винаходи, поєднуючи художню інтуїцію з аналітичним мистецтвом.

4. Уміння співпрацювати в системі «студент-викладач», розв’язуючи об'єктивно суперечності і рефлексію самооцінки власних творчих умінь.

5. Уміння трансформувати природні біонічні форми в змістовні художньообразні зображення, проводячи експериментальні дослідження.

6. Уміння застосовувати комп’ютерні технології: «Color Painter», «Adobe Photoshop», виготовляючи екологічний й енергозберігаючий продукт відповідно до вимог євростандартів.

7. Уміння проводити експерименти та науково-дослідницьку діяльність.

Висновки. Отже, обравши художньо-педагогічну діяльність майбутнього вчителя образотворчого мистецтва, нами було визначено ті творчі вміння, які $\epsilon$ поліхудожними, ефективними ц̆ універсальними. Вони можуть використовуватись як базові творчі вміння відповідно спеціалізації з різних художніх дисциплін: живопис, скульптура, розпис, кераміка, батик, вишивка, макраме тощо.

Творчі уміння вчитель реалізує в педагогічній діяльності, допомагає формувати творчі уміння школярів під час виконання самостійних класних завдань i, загалом, творчого продукту.

\section{References}

1. Danilenko V.I. Dizain : pidruchnyk [Design]. Harkiv: HDADM, 2003. 320 c.

2. Kuzmina N.V. Professionalism lichnosti prepodavatelya I mastera proizvodstvennogo obucheniya / [Professionality of teacher's and master's of craft education personality]. Moskva: Vysh. shk., 1990.

3. Programa rozvytku vishoi osvity Ukrainy «Osnovni zasady rozvytku vishoi osvity Ukrainy» [Development of higher education in Ukraine The main features of development of higher education of Ukraine]. Kyiv. 2008. Ch.4.

4. Sysoeva S.O. Osnovy pedagogichnoi tvorchostil [Basics of pedagogical art]: pidruchnyk. - Kyiv: Millenium, 2006. - 344 c. 
5. Ukrainskyi sovetskiy enciclopedycheskyi slovar: v 3-h t./ [Redcol.: A.V. Kudrickiy (otv. red.) i dr.]. [Ukrainian soviet encyclopedic dictionary]. Kyiv: Glav. Red. USE, 1989. $772 \mathrm{p}$.

6. Grigorenko Victoria, Matviienko Olena. The peculiarities in formation senior preschool children's attitude toward Arts and Crafts. Intellectual Archive. Toronto : Shiny Word.Corp. (Canada). 2017. March/April. Vol. 6. No. 2. PP. 83-91.

7. Pet'ko L.V. Brainstorming and the formation of professionally oriented foreign language teaching environment in the conditions of university (for the specialties 023 «Fine Arts» and 022 «Design»). Economics, management, law: challenges and prospects: Collection of scientific articles. Psychology. Pedagogy and Education. - Discovery Publishing House Pvt. Ltd., New Delhi, India. 2016. P. 214-217.

8. Pet'ko L.V. Development of students' cognitive activity in foreign language teaching by using analogy method. Actual problems of globalization: Collection of scientific articles. - Midas S.A., Thessaloniki, Greece, 2016. P. 232-237.

9. Pet'ko Lyudmila. Developing students' creativity in conditions of university. Research: tendencies and prospects: Collection of scientific articles. - Editorial Arane, S.A. de C.V., Mexico City, Mexico, 2017. - P. 272-276.

10. Pet'ko L.V. Formation of professionally oriented foreign language teaching environment in the conditions of university for students of art specialties. Economics, management, law: problems of establishing and transformation: Collection of scientific articles. - Al-Ghurair Printing \& Publishing LLC, Dubai, UAE, 2016. P. 395- 398.

11. Shevniuk O. Axiological Approach in Professional Preparation of Future Teachers of Fine Arts. Cultura - Sztuka - Edukacja. Tom 1. Krakow: Wydawnictwo naukowe universytetu pedagogicznego, 2015. P. 374-381.

12. Sova Olga. The essence and content of artistic-pedagogical skills in future teachers of Fine arts. Intellectual Archive. - Toronto: Shiny Word.Corp. (Canada). 2017. (March/April). Vol. 6. No. 6. PP. 66-79.

Translation of the Title, Abstract and References to the Author's Language

\section{УДК 378.016:7}

Пригодін М.Д. Формування творчих вмінь майбутніх вчителів художніх дисциплін у педагогічних закладах вищої освіти.

Висвітлено процес формування творчих умінь майбутнього вчителя художніх дисциплін у педагогічних навчальних закладах освіти. Разом з тим підкреслюється культурологічна спрямованість навчального процесу, де роль учителя, як суб'єкта педагогічного процесу, потребує вдосконалення системи освіти і утвердження національних цінностей на рівні європейських стандартів. Визначено базові творчі уміння, за допомогою яких можна створювати в цілому творчий продукт з подальшою художньою доробкою відносно специфіки даного виду мистецтва. Розглянуто художньо-естетичні напрями феномена «творчі уміння» в плані їх змістовності 3 адекватною майстерністю студента, майбутнього вчителя, його творчі пошуки, поєднані з наявними оптимальними педагогічними умовами і викладанням художніх 
навчальних дисциплін, що дозволяють глибше усвідомити діалектичний характер взаємозалежності змісту сформованих творчих умінь і професійності виконавця в особі вчителя.

Ключові слова: творчі уміння, майстерність, художні дисципліни (образотворче мистецтво, дизайн), педагогічна культура, естетика.

\section{Лimepamypa}

1. Даниленко В.Я. Дизайн: підручник. Харків: ХДАДМ, 2003. 320 с.

2. Кузьмина Н.В. Профессионализм личности преподавателя и мастера производственного обучения. Москва: Высш. шк., 1990.

3. Програма розвитку вищої освіти України «Основні засади розвитку вищої освіти України» [ Текст]. Київ 2008. Ч.4. $344 \mathrm{c}$.

4. Сисоєва С.О. Основи педагогічної творчості: підручник. Київ: Міленіум, 2006.

5. Украинский советский энциклопедический словарь: в 3-х т. / [Редкол.: А.В.Кудрицкий (отв. ред.) и др.]. Киев: Глав. ред. УСЭ, 1989. 772 с.: ил.

6. Grigorenko Victoria, Matviienko Olena. The peculiarities in formation senior preschool children's attitude toward Arts and Crafts. Intellectual Archive. Toronto : Shiny Word.Corp. (Canada). 2017. March/April. Vol. 6. No. 2. PP. 83-91.

7. Pet'ko L.V. Brainstorming and the formation of professionally oriented foreign language teaching environment in the conditions of university (for the specialties 023 «Fine Arts» and 022 «Design»). Economics, management, law: challenges and prospects: Collection of scientific articles. Psychology. Pedagogy and Education. - Discovery Publishing House Pvt. Ltd., New Delhi, India. 2016. P. 214-217.

8. Pet'ko L.V. Development of students' cognitive activity in foreign language teaching by using analogy method. Actual problems of globalization: Collection of scientific articles. - Midas S.A., Thessaloniki, Greece, 2016. P. 232-237.

9. Pet'ko Lyudmila. Developing students' creativity in conditions of university. Research: tendencies and prospects: Collection of scientific articles. - Editorial Arane, S.A. de C.V., Mexico City, Mexico, 2017. - P. 272-276.

10. Pet'ko L.V. Formation of professionally oriented foreign language teaching environment in the conditions of university for students of art specialties. Economics, management, law: problems of establishing and transformation: Collection of scientific articles. - Al-Ghurair Printing \& Publishing LLC, Dubai, UAE, 2016. - P. 395- 398.

11. Shevniuk O. Axiological Approach in Professional Preparation of Future Teachers of Fine Arts. Cultura - Sztuka - Edukacja. Tom 1. Krakow: Wydawnictwo naukowe universytetu pedagogicznego, 2015. P. 374-381.

12. Sova Olga. The essence and content of artistic-pedagogical skills in future teachers of Fine arts. Intellectual Archive. - Toronto: Shiny Word.Corp. (Canada). 2017. (March/April). Vol. 6. No. 6. PP. 66-79. 


\section{Manuscript Guidelines}

1. All submitted papers must contain the Title, Name of author(s), Affiliation (if any), Abstract and List of References (Literature) written in English. The Abstract must count not less than 100 and not more than 300 words and must be the good representation of your article. Optionally paper may also contain this information duplicated in another language.

2. Font faces. Arial, Times, Times New Roman, Courier New and Helvetica.

3. Language. You may use any language for your paper text, however English is MUCH preferable.

4. Title. Font size - 16, bold. Position - central alignment.

5. The author's name. Font size - 14, bold. Position - central alignment.

6. The affiliation (your University etc). Font size - 14, regular (not bold). Position - left alignment.

7. The word "Abstract". Font size - 12, bold-italics. Position - central alignment.

8. The text of the abstract. Font size - 10, regular (not bold).

9. The word "Keywords" (if any). Font size - 10, bold. Position - left alignment.

10. The text of keywords (if any). Font size - 10, regular (not bold). Position - left alignment.

11. Text of article. Font size - 14. Position - left alignment or fully justified. Line spacing - 1.5 lines.

12. The word "References" (if any). Font size - 12, bold-italics. Position - central alignment.

13. The text of References (if any). Font size - 12, regular (not bold).

In all other cases please use your own good judgment or contact our Editorial Board.

\section{Where to find us}

The "IntellectualArchive" is distributed to major libraries across Canada and the US, including

Library of Congress, USA (http://lccn.loc.gov/cn2013300046 ) ,

Library and Archives Canada

(http://collectionscanada.gc.ca/ourl/res.php?url_ver=Z39.88-2004\&url_tim=2012-09-

05T01\%3A46\%3A54Z\&url_ctx_fmt=info\%3Aofi\%2Ffmt\%3Akev\%3Amtx\%3Actx\&rft_dat=40904933\&r

fr_id=info\%3Asid\%2Fcollectionscanada.gc.ca\%3Aamicus\&lang=eng) and others.

The references to articles published in the "IntellectualArchive" are available in the

Google Scholar, (http://scholar.google.ca/scholar?q=\%22IntellectualArchive\%22 ),

Arxiv.org (http://search.arxiv.org:8081/?query=\%22Intellectual\%20Archive\%22\&in= ),

WorldCat.org (https://www.worldcat.org/search?q=n2\%3A1929-4700\&qt=advanced \&dblist=638 ) ,

Academia.edu

(http://www.academia.edu/15503799/Light_diffraction_experiments_that_confirm_the_STOE_model_and

_reject_all_other_models )

The National Research Council (Italy) (http://data.cnr.it/data/cnr/individuo/rivista/ID658222 )

Наукова бібліотека of the University named after Dragomanov, Ukraine

(http://enpuir.npu.edu.ua/handle/123456789/7974?mode=full )

Google.com (https://www.google.ca/\#q=site:IntellectualArchive.com ) thousands of links etc. 